
Estudos cromossômicos e reprodutivos em espécies de Mesosetum

Steud. (Poaceae: Paspaleae)

Tese de Doutorado apresentada ao Programa de PósGraduação em Botânica, Universidade de Brasília (UnB), como parte dos requisitos necessários para obtenção do título de doutor em Botânica.

Aluno: André Rodolfo de Oliveira Ribeiro

Orientador: Profa. Dra. Regina Célia de Oliveira - UnB

BRASÍLIA - DF

DEZEMBRO/2016 


\title{
Estudos cromossômicos e reprodutivos em espécies de Mesosetum
}

\author{
Steud. (Poaceae: Paspaleae)
}

APROVADA EM:

BANCA EXAMINADORA

Profa. Dra. Regina Célia de Oliveira, UnB

Presidente (Orientadora)

Profa. Dra. Carolyn Elinore Barnes Proença, UnB

Membro titular

Prof. Dr. Luiz Gustavo Rodrigues Souza, UFPE

Membro titular

Profa. Dra. Marisa Toniolo Pozzobon, EMBRAPA

Membro titular

Profa. Dra. Micheline Carvalho Silva, UFVJM

Membro titular

Profa. Dra. Sueli Maria Gomes, UnB

Suplente 
“A generosidade é a fonte restauradora das doenças espirituais e orgânicas." 
Aos meus queridos pais Adail Pereira

Ribeiro e Edna Maria de Oliveira. 


\section{AGRADECIMENTOS}

A Deus, pelo dom da vida, fonte inspiradora de todos os aprendizados. Pela confiança e oportunidade de fornecer minha singela contribuição ao progresso da ciência e da humanidade. A todos os espíritos dos planos superiores que me forneceram aprendizado.

Aos meus queridos pais Adail Pereira Ribeiro e Edna Maria de Oliveira, por me acolherem em família e pelo apoio incondicional aos meus estudos e trabalhos terrenos.

À Profa. Regina Célia de Oliveira por me acolher como aluno e aprendiz de botânica nestes 10 anos de caminhada. Por me confiar, indicar e fornecer parceria com os melhores cientistas da área.

Ao prof. Gustavo Souza pela confiança, pelos ensinamentos em citogenética e citometria, por me acolher no Laboratório de Citogenética e Evolução Vegetal, no qual tive a oportunidade de conhecer prof. Marcelo Guerra e profa. Andréa Pedrosa-Harand. Ainda ao prof. Gustavo pela oportunidade de fazer cursos e aprofundar no doutorado o conhecimento de citogenética que desenvolvi no mestrado. Por me apresentar à profa. Magdalena Vaio, a quem tenho muita admiração pelos trabalhos de citogenética em Poaceae e tive a honra de conhecer.

A todos os amigos que fiz no Lab. Citovegetal, que me acompanharam incansavelmente no aprendizado, Tiago Ribeiro, André Marques, Lucas, Jéssica, Brena, Mariela, Mariana, Lívia, Dani, Thallitha, Duda, Pablo, Tiago Esposito, Karol, Marcus, Sandra.

À profa. Andréa Pedrosa-Harand pela confiança e oportunidade concedida de participar do curso de Citometria de Fluxo com Dr. Joerg Fuchs e Dr. Andreas Houben que ocorreu no Lab. Citogenética e Evolução Vegetal. Este curso foi importantíssimo para o enriquecimento da minha tese. 
Conhecer o Andreas Houben, o pesquisador que orientou os trabalhos de FISH da espécie de Zingeria com $2 \mathrm{n}=8$ cromossomos, ir comer churrasco com ele e perceber uma pessoa extremamente competente e simples ao mesmo tempo foi surreal pra mim, um sonho que jamais imaginaria realizar dentro do Brasil, pertinho de casa no nordeste, em Recife. Algumas coisas acontecem e realmente não são coincidências.

Ao meu querido amigo Artur Fonseca, pelos ensinamentos em citogenética vegetal e pelos auxílios inestimáveis nos meus perrengues aqui de Brasília. Por me apresentar ao prof. Gustavo e ajudar a viabilizar minha ida a Recife. Relutei em ir e depois que cheguei a Recife não queria mais nem voltar (rsrsr). Esta viagem pra Recife foi muito importante pessoalmente para me descobrir e traçar projetos de vida futuros.

Às colegas de curso e amigas Priscila Alves dos Reis e Anádria Stéphanie da Silva pelo auxílio nas etapas de campo, elaboração de pranchas e fotos e discussão. Sem o apoio de vocês o trabalho não teria sido concluído.

A minha amiga Gláucia Figueiró, por ir na loja sede da Sigma em São Paulo brigar pelo último frasco de iodeto propídio (rsrsrsr), sem o qual a citometria de fluxo não teria sido concluída. Por me inspirar na discussão e no andamento do trabalho, com seu exemplo de não se abater mesmo enfrentando um câncer no meio da sua tese de doutorado.

Ao meu querido amigo Antonio Gabriel, pela parceria nos trabalhos de citogenética desenvolvidos na UnB, por me ajudar a cuidar das mudas, sempre muito prestativo.

Ao meu querido amigo Jair Faria que no seu carro pessoal ajudou a fazer expedições de coleta comigo, quando o carro oficial da UnB estava quebrado para saídas de campo. Com sua parceria e experiência no campo encontrei Mesosetum gibbosum, M. ferrugineum, $M$. rottboellioides, M. cayennense, M. comatum, Tatianyx arnacites e minha tese deu salto substancial. Por auxiliar sempre trazendo coletas de gramíneas e às vezes até algumas mudas. 
À minha amiga Janae Milion, pelos auxílios quando tive dificuldade em traduzir textos em língua inglesa. À minha amiga Jéssika Vieira, pela companhia e por segurar as pontas no herbário nos momentos finais da tese, quando tive que investir maior esforço na redação e análise dos dados do doutorado.

A todos aqueles que contribuíram com o andamento deste trabalho.

Aos meus familiares pelo apoio e motivação sempre! Vó Aurinha, vó Raimunda, vô Domício, meus irmãos Aldo, Andréa, Aline e Suelen, tia Gorete, tia Maria Gomes, tia Evandissa, primo Ricardo, tia Adriana, primos Isaac, Bruno, Jacob, Rodolfo e Paulo Henrique, primas Carla, Daniela e Fernandinha (minha Júlia Roberts brasileira), tia Ednelvia, tia Edvânia, tio Fred. Minhas sobrinhas fofurinhas Maria Clara e Maria Sofia.

Aos meus amigos Bruna Ilha, Renata Costa, Phillip, Kadja Milena, Leo Resende, Fernanda, por todo o apoio e motivação sempre. 


\section{Resumo}

Em Poaceae, a subfamília Panicoideae possui cerca de 3500 espécies e é a mais diversa nas regiões tropicais. Os números cromossômicos básicos $\mathrm{x}=5, \mathrm{x}=9 \mathrm{e} \mathrm{x}=10$ e genomas pequenos $(2 \mathrm{C} / 2 \mathrm{n}=0,1 \mathrm{pg})$ predominam entre as espécies de Panicoideae. Os diploides têm meiose estável e alta viabilidade polínica, enquanto os poliploides apresentam viabilididade polínica variável e diretamente relacionada ao índice meiótico. Mesosetum Steud. possui 25 espécies e é o único gênero neotropical de Panicoideae com registro do número cromossômico $2 \mathrm{n}=8(\mathrm{x}=4)$, cuja origem a partir de $\mathrm{x}=10$, também encontrado no gênero, ainda não foi elucidada. O objetivo da presente tese de doutorado foi obter dados sobre número e morfologia cromossômica, tamanho do genoma e fertilidade do pólen e relacionálos à árvore filogenética molecular de Mesosetum. Os dados sobre número cromossômico e tamanho do genoma foram obtidos em 20 acessos e 13 espécies de Paspaleae, sendo uma espécie de Arthropogon Nees, 10 espécies de Mesosetum, uma espécie de Spheneria Kuhlm. e uma espécie de Tatianyx Zuloaga \& Soderstr. O número cromossômico $2 \mathrm{n}=26(\mathrm{x}=13)$ observado em M. exaratum (Trin.) Chase é aqui registrado pela primeira vez na subfamília Panicoideae. Em Mesosetum, é possível reconhecer pelo menos três linhagens relacionadas a distintos números cromossômicos. O clado com número cromossômico básico $\mathrm{x}=10$ é provavelmente o mais basal em Mesosetum e, a partir do qual, se derivaram o clado com $\mathrm{x}=4$ e a linhagem monoespecífica com $x=13$. O clado com $x=4$ provavelmente se derivou por fusão ou rearranjos cromossômicos. Os cromossomos das espécies com $2 n=8,2 n=16$ e 2n $=$ 24 mostraram sinais de DNAr 5S e 45S que confirmaram a ocorrência de poliploidia no clado $\mathrm{x}=4$. Os dados de citometria de fluxo sugerem que o clado com $\mathrm{x}=10$ manteve genoma pequeno $(2 \mathrm{C} / 2 \mathrm{n}=0,04$ a $0,1 \mathrm{pg})$ com cromossomos menores $(1,8-4,0 \mu \mathrm{m})$. No clado com $\mathrm{x}=$ 4 e na linhagem monoespecífica com $x=13$ provavelmente ocorreu uma expansão do tamanho do genoma após os eventos de disploidia descendente. Foi verificada uma redução 
do genoma dos poliploides naturais, sugerindo que já houve algum grau de diploidização após o evento de poliploidização. Esta diploidização também suporta a estabilidade meiótica e alta fertilidade do pólen observadas na maioria dos poliploides de Mesosetum.

Palavras-chaves: citogenética, Panicoideae, citometria de fluxo, reprodução

\section{Abstract}

In Poaceae, the subfamily Panicoideae contains approximately 3500 species and is the most diverse grass subfamily of tropical regions. The basic chromosome numbers of $x=5, x=9, x$ $=10$, and small genomes $(2 \mathrm{C} / 2 \mathrm{n}=0.1 \mathrm{pg})$ are predominant among Panicoideae species. Diploids have stable meiosis and high pollen viability, while polyploids have variable pollen viability, which is directly related to the meiotic index. Mesosetum Steud. is composed of 25 species and is the only neotropical genus of Panicoideae with a registered chromosome number of $2 n=8(x=4)$. The origin of $x=4$ basic chromosome number from $x=10$, which also found within the genus, is still unknown. The aim of the present doctoral thesis was to obtain data about chromosome number and morphology, genome size, pollen fertility, and to relate to the molecular phylogenetic tree of Mesosetum. The data concerning chromosome number and genome size were obtained from 20 accessions and 13 species, including one species of Arthropogon Nees, 10 species of Mesosetum, one species of Spheneria Kuhlm., and one species of Tatianyx Zuloaga \& Soderstr. The chromosome number of $2 \mathrm{n}=26(\mathrm{x}=$ 13), found in M. exaratum (Trin.) Chase, is registered here for the first time for the subfamily Panicoideae. In Mesosetum, at least three lineages can be possible related through distinct basic chromosome numbers. The clade with the basic chromosome number of $x=10$ is probably the most basal in Mesosetum, from which $\mathrm{x}=4$ clade and $\mathrm{x}=13$ monospecific lineage were derived. The $\mathrm{x}=4$ clade was probably derived via fusion or chromosomal rearrangements. The chromosomes of the species with $2 \mathrm{n}=8,16$, and 24 showed signals of 
5S and 45S rDNA that confirmed the occurrence of polyploidy in the $\mathrm{x}=4$ clade. The flow cytometry data suggest that a small genome size $(2 \mathrm{C} / 2 \mathrm{n}=0.04$ a $0.1 \mathrm{pg})$ and the smallest chromosomes of the genus $(1.8-4.0 \mu \mathrm{m})$ were conserved in the $\mathrm{x}=10$ clade. In the $\mathrm{x}=4$ clade and $\mathrm{x}=13$ lineage, a genome size expansion probably occurred after events of descending disploidy. A decrease in the genome size was verified in natural polyploids, suggesting that some level of diploidization occurred after the polyploidization event. This diploidization also supports the meiotic stability and high pollen fertility observed in the majority of Mesosetum polyploids.

Keywords: citogenetic, Panicoideae, flow cytometry, reproduction 


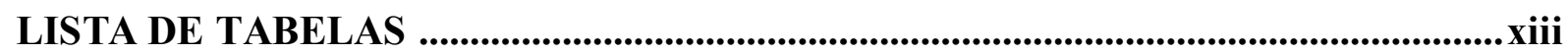

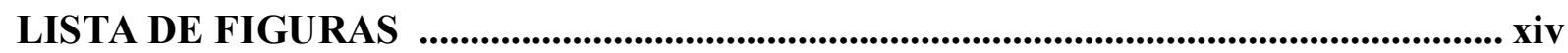

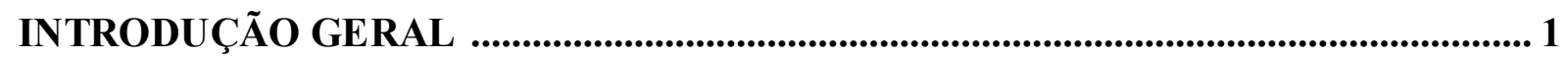

A variação dos números cromossômicos em Poaceae e sua evolução ...................................... 1

O gênero Mesosetum e sua variação de números cromossômicos ............................................. 4

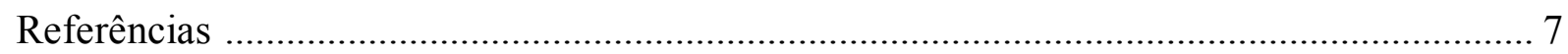

CAPÍtUlo 1: Estudos cromossômicos em espécies de Mesosetum Steud. (Poaceae:

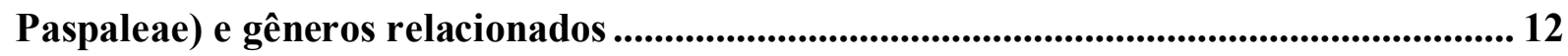

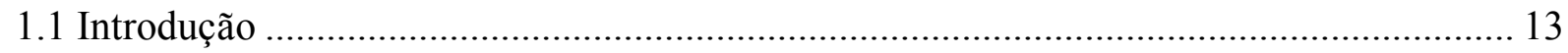

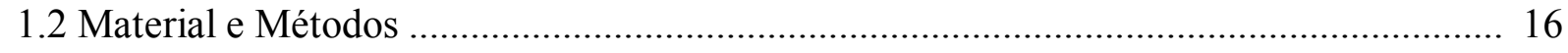

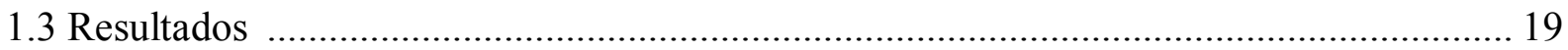

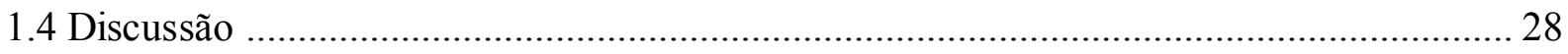

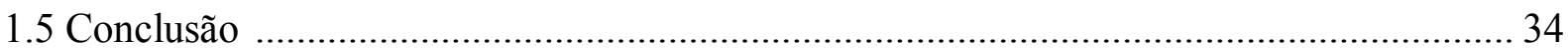

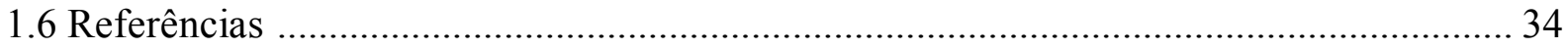

CAPÍTULO 2: Estudos de citometria de fluxo e tamanho do genoma em espécies de Mesosetum Steud. (Poaceae: Paspaleae) e outros gêneros de Arthropogoninae .............. 43

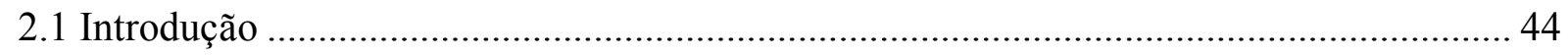

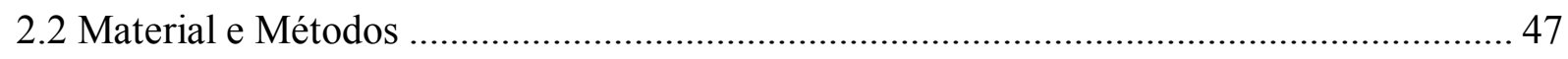

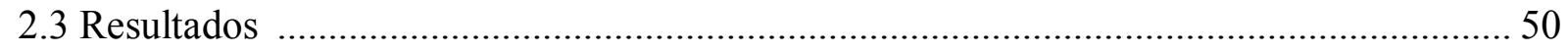

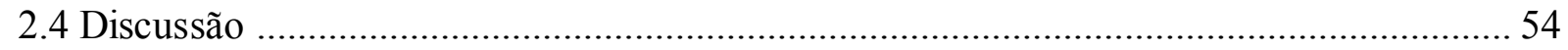

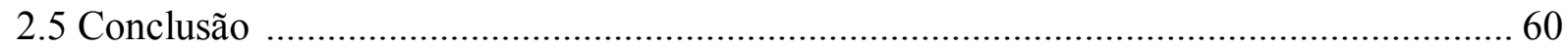

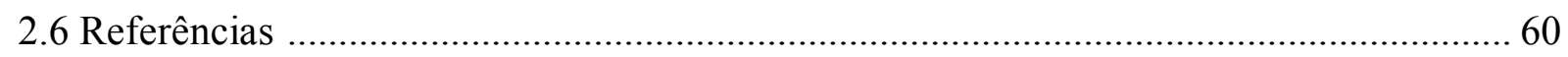


CAPÍTULO 3: Estudos de citogenética molecular em espécies de Mesosetum sect. Bifaria

(Hack.) Chase (Poaceae: Arthropogoninae) ..................................................................66

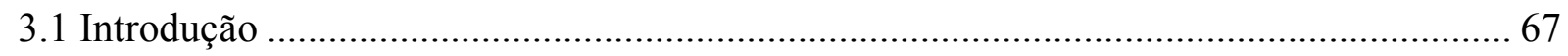

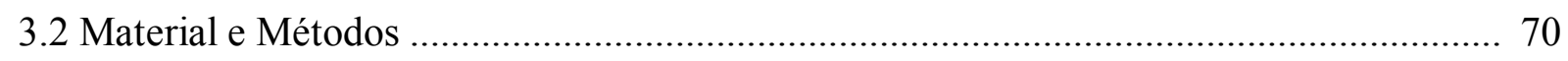

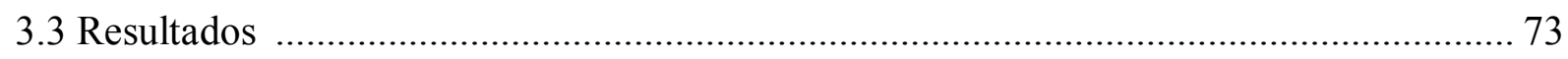

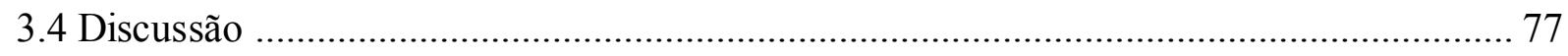

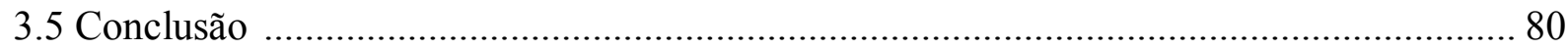

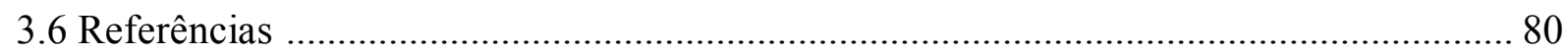

CAPÍTULO 4: Estudos de viabilidade polínica em espécies de Mesosetum Steud.

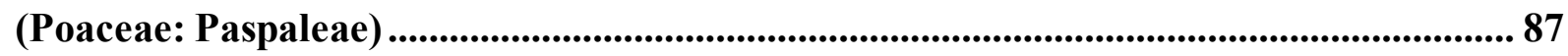

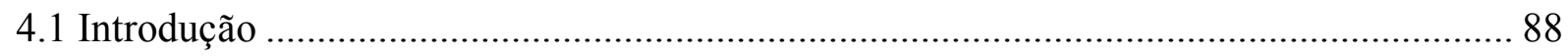

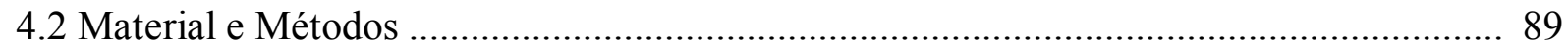

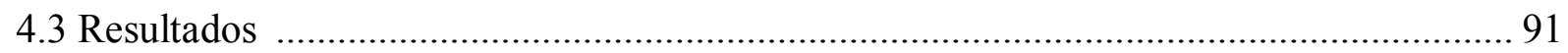

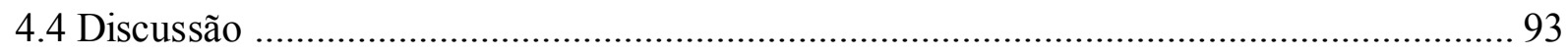

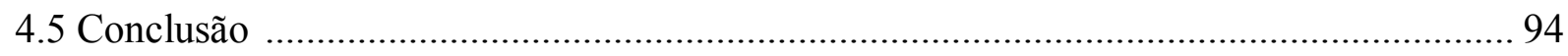

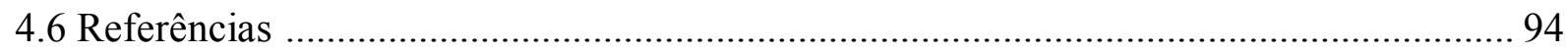

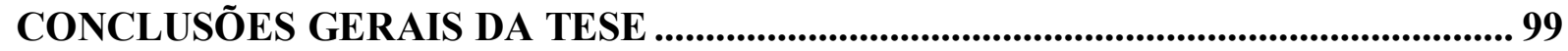




\section{LISTA DE TABELAS}

\section{CAPÍTULO 1}

Tabela 1. Espécies e acessos de Mesosetum com metáfases mitóticas avaliadas em dupla coloração com CMA-DAPI

Tabela 2. Números cromossômicos observados em espécies de Arthropogoninae e Paspalinae

Tabela 3. Variação do tamanho cromossômico entre os cromossomos observados em metáfases mitóticas de espécies de Mesosetum e Tatianyx

Tabela 4. Espécies de Poaceae com $2 \mathrm{n}=26$ cromossomos de acordo com a base de dados de Goldblatt \& Johnson (2016) e enriquecida com revisão de literatura da presente tese de doutorado 28

\section{CAPÍTULO 2}

Tabela 1. Discriminação das espécies de Mesosetum e outros gêneros de Arthropogoninae com respectivos acessos e locais de coleta utilizados nas análises de citometria de fluxo 48

Tabela 2. Quantidade de DNA do genoma diplofásico (2C) das espécies de Arthropogon, Mesosetum e Tatianyx estimadas por citometria de fluxo, seus respectivos números cromossômicos, nível de ploidia, quantidade de DNA do genoma monoploide (Cx) e quantidade média de DNA por cromossomo $(2 \mathrm{C} / 2 \mathrm{n})$

\section{CAPÍTULO 3}

Tabela 1. Espécies de Mesosetum e respectivos acessos caracterizados via citogenética molecular

\section{CAPÍTULO 4}

Tabela 1. Discriminação das espécies e acessos de Mesosetum com viabilidade polínica avaliada. 90

Tabela 2. Viabilidade polínica e Índice Meiótico em espécies de Mesosetum 91 


\section{LISTA DE FIGURAS}

\section{CAPÍTULO 1}

Figura 1. Células em meiose mostrando os cromossomos de espécies de Arthropogoninae e Paspalinae. 22

Figura 2. Células em mitose coradas com DAPI mostrando os cromossomos de espécies de Arthropogoninae. 23

Figura 3. Metáfases mitóticas de espécies de Mesosetum com $\mathrm{x}=10$ e $\mathrm{x}=13$ coradas com CMA (amarelo) e DAPI (azul). 24

Figura 4. Dados de número cromossômico do presente trabalho enriquecidos por revisão de literatura e plotados na árvore filogenética das espécies de Mesosetum elaborada por Silva (dados não publicados) baseada em análise bayesiana combinada dos marcadores ITS, trnLF, psbA-trnH e matK. 25

\section{CAPÍTULO 2}

Figura 1. Histogramas das quantidades de DNA (2C) relativas obtidas de núcleos isolados em tecidos de folhas jovens em espécies de Arthropogoninae com número cromossômico básico $x=10$

Figura 2. Histogramas das quantidades de DNA (2C) relativas obtidas de núcleos isolados em tecidos de folhas jovens em espécies de Mesosetum com números cromossômicos básicos x = 10 e $\mathrm{x}=13$

\section{CAPÍTULO 3}

Figura 1. Metáfases mitóticas de espécies de Mesosetum sect. Bifaria com $2 \mathrm{n}=8$ e $2 \mathrm{n}=16$ cromossomos após hibridização in situ com DNAr 5S (fluorescente em alaranjado) e DNAr 45S (fluorescente em verde) com contracoloração em DAPI (cinza) vistas em microscópio com epifluorescência. 74

Figura 2. Metáfases mitóticas de espécies de Mesosetum sect. Bifaria com $2 \mathrm{n}=24$ cromossomos após hibridização in situ com DNAr 5S (fluorescente em alaranjado) e DNAr 
45S (fluorescente em verde) com contracoloração em DAPI (cinza) vistas em microscópio com epifluorescência.

Figura 3. Idiogramas das espécies de Mesosetum sect. Bifaria com $2 n=8$ e $2 n=16$ cromossomos com sítios de DNAr 5S (laranja), DNAr 45S (verde) e bandas DAPI (cinza)......

Figura 4. Idiogramas das espécies de Mesosetum sect. Bifaria com $2 \mathrm{n}=24$ cromossomos com sítios de DNAr 5S (laranja), DNAr 45S (verde) e bandas DAPI (cinza). 75

\section{CAPÍTULO 4}

Figura 1. Grãos de pólen corados com carmim acético em espécies de Mesosetum . .92 


\section{INTRODUÇÃO GERAL}

\section{A variação dos números cromossômicos em Poaceae e sua evolução}

Poaceae é uma das maiores famílias de angiospermas com cerca de 700 gêneros e 12000 espécies distribuídas desde o equador até as zonas polares (Watson \& Dallwitz 2016). A evolução das espécies de Poaceae seguiu uma sequência de eventos de aumento e redução do genoma (Hunziker \& Stebbins 1987; Leitch et al. 2010; Soreng et al. 2015; Wang et al. 2015). Enquanto o aumento do genoma ocorreu relacionado à poliploidia, a redução do genoma processou-se paralela à diploidização (Hilu 2004; Kellog \& Benetzen 2004; Parteson et al. 2004; Schnable et al. 2012; Zhao et al. 2015; Wang et al. 2015; Studer et al. 2016).

Este modelo evolutivo acarretou uma ampla diversidade de tamanho e números cromossômicos entre as distintas subfamílias de Poaceae (Schapova 2012). São reportados números básicos variando de $\mathrm{x}=2 \mathrm{a} x=18$, com números somáticos desde $2 \mathrm{n}=4$ a $2 \mathrm{n}=263$ 265 (De Wet 1987, Hilu 2004, Schapova 2012).

Anomochlooideae, a subfamília mais basal de Poaceae, inclui quatro espécies petencentes a dois gêneros florestais endêmicos dos Neotrópicos (Anomochloa Brongn. e Streptochaeta Schrad. ex Nees) e reporta os números cromossômicos básicos $\mathrm{x}=11$ ou $\mathrm{x}=18$ (GPWG 2001; Hilu 2004; Soreng et al. 2015).

Pooideae possui cerca de 4200 espécies e é a mais diversa entre as regiões temperadas e as zonas polares ártica e antártica (GPWG 2001; Soreng et al. 2015; McKeown et al. 2016). A subfamília Pooideae é peculiar pela alta diversidade de números cromossômicos básicos (GPWG 2001; Hilu 2004; Schapova 2012). O número básico $\mathrm{x}=7$ é predominante em Pooideae, porém ainda são reportados desde $\mathrm{x}=2$ até $\mathrm{x}=13$ (Kotseruba et al. 2003; Hilu 2004; Cremonini et al. 2003; Schapova 2012;). Eventos disploides resultaram em uma extrema redução do número cromossômico nos gêneros Zingeria P.A. Smirn. e Colpodium Trin. com $2 \mathrm{n}=4(\mathrm{x}=2)$, o qual é o menor número cromossômico conhecido entre as angiospermas (Cremonini et al. 2003; Hilu 2004). O maior número cromossômico de Poaceae 
e mais alto nível de ploidia também foram registrados na subfamília Pooideae, em Poa litorosa Cheeseman com $2 \mathrm{n}=263-265$ e nível 38-ploide com $\mathrm{x}=7$ (Hunziker \& Stebbins 1987). Essa diversidade é atribuída aos extremos ambientais de frio e calor nas regiões temperadas, que interferem na formação dos fusos e acarretam irregularidades mitóticas e meióticas, gerando descendentes com números cromossômicos distintos dos parentais (Hilu 2004, Amosova et al. 2015).

Panicoideae é a subfamília mais diversa na zona tropical e possui cerca de 3500 espécies (GPWG 2001; Soreng et al. 2015; Burke et al. 2016). Panicoideae tem como números cromossômicos básicos mais freqüentes $\mathrm{x}=9 \mathrm{e} \mathrm{x}=10$, mas ainda há registros de $\mathrm{x}=$ 3-8, $\mathrm{x}=11-12$ e x $=14$ (Celarier \& Paliwal 1957, Rao 1975; De Wet 1987; GPWG 2001; Hilu 2004; Morrone et al. 2006; Sede et al. 2010; Goldblatt \& Johnson 2016).

No entanto, em algumas subfamílias os padrões de número e evolução cromossômica permanecem pouco compreendidos pela carência de informação. A ausência de contagens cromossômicas é evidente em significativo número de espécies distribuídas pelos Trópicos e Subtrópicos (Honfi et al. 1991, Sede et al. 2010) e ainda mais relevante é a carência de estudos avançados via citogenética molecular e ensaios reprodutivos que investiguem o grau de homeologia dos cromossomos entre espécies relacionadas. Por este motivo, para se compreender a origem e tendência de evolução dos números cromossômicos em Poaceae ainda são requeridos muitos estudos citogenéticos.

A tendência de evolução cromossômica em Poaceae, conforme avalia De Wet (1987), é dos maiores grupos terem se derivado independentemente de um complexo original de espécies com $\mathrm{x}=5, \mathrm{x}=6 \mathrm{e} \mathrm{x}=7$. Após um processo de diploidização no nível tetraploide, surgiram os números básicos secundários de $\mathrm{x}=10, \mathrm{x}=12$ e $\mathrm{x}=14$.

Hilu (2004), investigando a relação dos gêneros mais basais de Poaceae, Anomochloa e Streptochaeta, com os grupos irmãos representados pelas famílias Ecdeiocoleaceae, 
Joinvilleaceae e Restionaceae, cita $\mathrm{x}=11$ como número básico ancestral de Poaceae, a partir do qual derivou-se $\mathrm{x}=12$, o qual também é encontrado em outras gramíneas basais.

Murat et al. (2010) reconstruiu o cariótipo ancestral de Poaceae e das subfamílias Ehrhartoideae (atualmente em Oryzoideae), Panicoideae e Pooideae, avaliando espécies com genoma totalmente sequenciado e dados citogenéticos. Conforme o modelo de Murat et al. (2010) cinco protocromossomos $(x=5)$ originaram por poliploidização, duplicação e rearranjos o cariótipo ancestral de Poaceae com $\mathrm{x}=12$, corroborando a hipótese de De Wet (1987) e parcialmente a hipótese de Hilu (2004). As diferenças nas análises podem refletir o fato de Murat et al. (2010) não ter utilizado representantes basais da subfamília Anomochloideae nem das famílias Ecdeiocoleaceae, Joinvilleaceae e Restionaceae, que são grupos irmãos de Poaceae.

Schapova (2012) formulou a hipótese de que o número cromossômico básico ancestral de Poaceae poderia ser $\mathrm{x}=1,2$ ou 3, o qual evoluiu a partir de euploidia, disploidia e hibridização. Entretanto, Schapova (2012) não cita a relação de $x=1-3$ com os grupos irmãos de Poaceae, nem releva o fato de os gêneros e espécies mais basais de Poaceae registrarem como números básicos $\mathrm{x}=11 \mathrm{e} \mathrm{x}=18$.

Na subfamília Panicoideae, a hipótese de evolução cromossômica sugere que $\mathrm{x}=11$ é o número básico ancestral desta subfamília, encontrado no monotípico basal representado por Gynerium sagittatum (Aubl.) P. Beauv. (Hilu 2004). A partir de $\mathrm{x}=11$ se derivaram sucessivamente por redução os números $\mathrm{x}=10, \mathrm{x}=9$ e $\mathrm{x}=5$ (Hilu 2004). Após eventos de alopoliploidia o número básico de $\mathrm{x}=10$ foi restaurado a partir de $\mathrm{x}=5$ (Hilu 2004, Murat et al. 2010). Embora $\mathrm{x}=5, \mathrm{x}=9$ e $\mathrm{x}=10$ sejam os números cromossômicos predominantes em Panicoideae, são reportados números cromossômicos mais raros como $\mathrm{x}=3$ e x $=4$ (Celarier \& Paliwal 1957; Rao 1975; De Wet 1987; GPWG 2001; Hilu 2004; Goldblatt \& Johnson 2016). Os números básicos $x=3$ e $x=4(2 n=6$ e $2 n=8)$ são também os mais baixos já 
registrados entre as gramíneas tropicais, sendo reportados unicamente no gênero Iseilema Andersson (tribo Andropogoneae) e Mesosetum Steud. (tribo Paspaleae) (Celarier \& Paliwal 1957; Rao 1975; De Wet 1987; Morrone et al. 2012; Ribeiro 2013; Sousa 2014; Ribeiro et al. 2015). No caso dos números mais reduzidos $\mathrm{x}=3$ e $\mathrm{x}=4$ registrados no gênero Iseilema teriam derivado a partir de $u m x=5$ provavelmente por perda de centrômeros e rearranjos cromossômicos (Rao 1975). Em Mesosetum, a origem de $\mathrm{x}=4$ ainda é desconhecida (Ribeiro 2013; Sousa 2014; Ribeiro et al. 2015).

O gênero Mesosetum foi posicionado na tribo Paspaleae e na subtribo Arthropogoninae (Morrone et al. 2012). Entre seus gêneros, Mesosetum é o que apresenta maior diversidade. Dentro de Arthropogoninae, Mesosetum forma um clado altamente suportado com os gêneros monoespecíficos Tatianyx Zuloaga \& Soderstr. e Keratochlaena Morrone (Morrone et al. 2012).

\section{O gênero Mesosetum e sua variação de números cromossômicos}

Mesosetum Steud. é um gênero neotropical que compreende 25 espécies campestres, distribuídas desde o sul do México ao nordeste da Argentina (Filgueiras 1989; Filgueiras et al. 2016). O Brasil é o centro de diversidade do gênero, com 22 espécies (Filgueiras 1989, Filgueiras et al. 2016; Silva et al. 2016). Morfologicamente, o gênero é reconhecido pelas inflorescências com um ramo unilateral espiciforme, espiguetas com a primeira gluma adaxial à ráquis e cariopse com hilo linear (Filgueiras 1986, 1989).

Allem \& Valls (1987) e Santos et al. (2002) indicaram potencial forrageiro em pelo menos duas espécies, Mesosetum loliiforme (Hochst. ex Steud.) Chase e M. chaseae Luces, por sua grande capacidade de produzir estolhos e afilhamento intenso. Entretanto, no Brasil os estudos com forrageiras nativas ainda são incipientes (Silva 2008), e ainda carecem de informações técnicas que atestem com maior precisão seu potencial forrageiro. 
A primeira revisão para Mesosetum foi feita por Swallen (1937), que considerou 33 espécies no gênero. Swallen (1937) baseou seu estudo em grande número de coletas pelo Brasil e propôs a subdivisão de Mesosetum em seis seções (Annua Swallen, Bifaria (Hack.) Chase, Fulva Swallen, Loliiformia Swallen, Penicillata Swallen e Schlerochloae Swallen) e mais um conjunto de sete espécies denominado "ungrouped species".

A última revisão taxonômica de Mesosetum, proposta por Filgueiras (1986), reconheceu 25 espécies em Mesosetum, agrupando-as em cinco seções: Bifaria (Hack.) Chase, Loliiformia Swallen, Mesosetum, Penicillata Swallen e Schlerochloae Swallen. Filgueiras (1986) elaborou uma árvore evolutiva das espécies de Mesosetum com base em caracteres morofológicos. A seção Penicillata foi posicionada por Filgueiras (1986) no clado mais basal e a seção Bifaria no mais derivado, com as espécies da seção Loliiformia apresentando morfologia intermediária.

As primeiras informações de número cromossômico para o gênero encontradas na literatura eram restritas a três espécies: Mesosetum chaseae, M. loliiforme e M. pittieri Hitchc., com $2 \mathrm{n}=16$ cromossomos e $\mathrm{x}=8$ (Gould 1966; Gould \& Soderstrom 1967; Pohl \& Davidse 1971; Davidse \& Pohl 1972; Silva et al. 2012). Sede et al. (2010) citaram outro citótipo $2 \mathrm{n}=32$ para a espécie $M$. loliiforme.

Estudos com enfoque citotaxonômico no gênero Mesosetum analisaram 12 espécies e revelaram diversidade acerca dos números cromossômicos, reportando pela primeira vez os números de $2 \mathrm{n}=8,2 \mathrm{n}=24,2 \mathrm{n}=20$ e $2 \mathrm{n}=60$ cromossomos (Ribeiro 2013, Sousa 2014, Ribeiro et al. 2015). Estes resultados sugerem pelo menos dois números cromossômicos básicos $(\mathrm{x}=4$ e $\mathrm{x}=10)$ para o gênero.

Uma árvore filogenética incluindo 24 espécies de Mesosetum e outros gêneros externos está sendo elaborada com base nos marcadores moleculares ITS (Internal Transcriber Spacer), trnL-F, psbA-trnH e matK (Silva dados não publicados). Os resultados 
parciais deste estudo molecular mostram pelo menos dois clados correspondentes aos dois números cromossômicos básicos $\mathrm{x}=4 \mathrm{e} \mathrm{x}=10$. O gênero Tatianyx ocupa ramo dentro do clado das espécies de Mesosetum (Silva dados não publicados). A síntese dos estudos citogenéticos combinados aos dados moleculares sugerem que a redução do número cromossômico e a poliploidia atuaram na evolução das espécies de Mesosetum. A maior parte dos poliploides de Mesosetum apresentam meiose estabilizada e alta viabilidade polínica, sugerindo que já se processou algum grau de diploidização ou redução do tamanho do genoma nos poliploides.

Buscando verificar estas hipóteses, o principal objetivo desta tese de doutorado foi realizar estudos citogenéticos e reprodutivos por meio de análises dos cromossomos, citometria de fluxo e viabilidade polínica no maior número possível de espécies de Mesosetum, bem como em alguns representantes de outros gêneros de Paspaleae.

Para organização do texto, a presente tese de doutorado foi divida em quatro capítulos, o primeiro sobre números e morfologia dos cromossomos, o segundo sobre citometria de fluxo, o terceiro sobre citogenética molecular e o quarto sobre viabilidade polínica. A formatação geral do texto baseou-se nas normas da revista "Plant Systematics and Evolution" 


\section{Referências}

Allem AC, Valls JFM (1987) Recursos forrageiros nativos do pantanal Matogrossense. EMBRAPA/DID: EMBRAPA/CENARGEN, Documentos 8

Amosova AV, Bolsheva NL, Samatadze TE, Twardovska MO, Zoshchuk SA, Andreev IO, Badaeva ED, Kunakh VA, Muravenko OV (2015) Molecular Cytogenetic Analysis of Deschampsia antarctica Desv. (Poaceae), Maritime Antarctic. PLoS ONE 10(9): 1-17

Burke SV, Wysocki WP, Zuloaga FO, Craine JM, Pires JC, Edger PP, Mayfield-Jones D, Clark LG, Kelchner SA, Duvall MR (2016) Evolutionary relationships in Panicoid grasses based on plastome phylogenomics (Panicoideae; Poaceae). BMC Plant Biology 16(140): 1-11

Celarier R, Paliwal R (1957) Basic chromosome number of four in the subfamily Panicoideae of the Gramineae. Science 126: 1247

Cremonini R, Ruffini Castiglione M, Grif VG, Kotseruba VV, Punina EO, Rodionov AV, Muravenko OV, Popov KV, Samatadze TE, Zelenin AV (2003) Chromosome banding and DNA methylation patterns, chromatin organisation and nuclear DNA content in Zingeria biebersteiniana. Biologia Plantarum 46: 543-550

Cremonini R (2005) Low chromosome number angiosperms. Caryologia 58(4): 403-409

Davidse G, Pohl RW (1972) Chromosome numbers, meiotic behavior, and notes on some grasses from Central America and the West Indies. Canadian Journal of Botany 50: $1441-1452$

De Wet JMJ (1987) Hybridization and polyploidy in the Poaceae. In: Soderstrom TR, Hilu KW, Campbell CS, Barkworth MA (eds.) Grass systematics and evolution, Smithsonian Inst. Press., Washington DC, pp 188-194

Filgueiras TS (1986) O gênero Mesosetum Steudel (Gramineae: Paniceae). Tese de Doutorado, Universidade Estadual de Campinas, Campinas-SP, Brazil 
Filgueiras TS (1989) Revisão de Mesosetum Steudel (Gramineae: Paniceae). Acta Amazônica 19: 47-114

Filgueiras TS, Silva AS, Oliveira RC (2016) Mesosetum In Lista de Espécies da Flora do Brasil. Jardim Botânico do Rio de Janeiro, Brazil. Available at: http://floradobrasil.jbrj.gov.br/jabot/floradobrasil/FB13355, Accessed 18 Jan. 2016

Goldblatt P, Johnson DE (2016) Index to plant chromosome numbers 1979-onwards. Missouri Botanical Garden, St. Louis, USA. Available at: http://www.tropicos.org/Project/IPCN, Accessed 23 Nov. 2016

Gould FW (1966) Chromosome numbers of some Mexican grasses. Canadian Journal of Botany 44: 1683-1696

Gould FW, Soderstrom TR (1967) Chromosome numbers of tropical American grasses. American Journal of Botany 54: 676-683

Group GGPW (2001) Phylogeny and subfamilial classification of the grasses (Poaceae). Annals of the Missouri Botanical Garden 88(3): 373-457

Hilu K (2004) Phylogenetics and chromosomal evolution in the Poaceae (grasses). Australian Journal of Botany 52: 13-22

Honfi AI, Quarín CL, Valls JFM (1991) Estudios cariológicos en gramíneas sudamericanas. Darwiniana 30: 87-94

Hunziker JH, Stebbins GL (1987) Chromosome evolution in the Gramineae. In: Soderstrom TR, Hilu KW, Campbell CS, Barkworth MA (eds.) Grass Systematics and Evolution, Smithsonian Inst., Washington, pp 179-187

Kellogg EA, Bennetzen JL (2004) The evolution of nuclear genome structure in seed plants. American Journal of Botany 91(10): 1709-1725

Kotseruba VV, Gernand D, Meister A, Houben A (2003) Uniparental loss of ribosomal DNA in the allotetraploid grass Zingeria tricopoda $(2 \mathrm{n}=8)$. Genome 46: 156-163 
Leitch IJ, Beaulieu JM, Chase MW, Leitch AR, Fay MF (2010) Genome Size Dynamics and Evolution inMonocots. Journal of Botany ID 862516: 1-18

McKeown M, Schubert M, Marcussen T, Fjellheim S, Preston JC (2016) Evidence for an Early Origin of Vernalization Responsiveness in Temperate Pooideae Grasses. Plant Physiology 172: 416-426

Morrone O, Escobar A, Zuloaga FO (2006) Chromosome studies in American Panicoideae (Poaceae). Annals of the Missouri Botanical Garden 93: 647-657

Morrone O, Aagesen L, Scataglini MA, Salariato DL, Denham SS, Chemisquy MA, Sede SM, Giussani LM, Kellogg EA, Zuloaga FO (2012) Phylogeny of the Paniceae (Poaceae: Panicoideae): integrating plastid DNA sequences and morphology into a new classification. Cladistics 28: 333-356

Murat F, Xu J-H, Tannier E, Abrouk M, Guilhot N, Pont C, Messing J, Salse J (2010) Ancestral grass karyotype reconstruction unravels new mechanisms of genome shuffling as a source of plant evolution. Genome Research 20: 1545-1557

Paterson AH, Bowers JE, Chapman BA (2004) Ancient polyploidization predating divergence of the cereals, and its consequences for comparative genomics. Proceedings of the National Academy of Sciences of the United States of America 101(26): 9903-9908

Pohl RW, Davidse G (1971) Chromosome numbers of Costa Rican grasses. Brittonia 23: 293324

Rao Y (1975) Evolutionary trends in the Indian Iseilema. Nature 255: 220-221

Ribeiro ARO (2013) Citogenética, reprodução e variabilidade morfológica de espécies de Mesosetum sect. Bifaria (Hack.) Chase (Poaceae: Paniceae). Dissertação de Mestrado, Universidade de Brasília, Brasília-DF, Brazil

Ribeiro ARO, Sousa MWS, Oliveira RC, Araujo ACG, Fagg CW, Pozzobon MT (2015) Cytological studies in four species of Mesosetum (Arthropogoninae) reveal the lowest 
chromosome number among the Neotropical Poaceae. Plant Systematics and Evolution 301(10): 2377-2386

Santos SA, Costa C, Souza GS, Pott A, Alvarez JM, Machado SR (2002) Composição Botânica da Dieta de Bovinos em Pastagem Nativa na Sub-Região da Nhecolândia, Pantanal. Revista Brasileira de Zootecnia 31(4): 1648-1662

Schapova AI (2012) Evolution of the Basic Chromosome Number in Poaceae Barnh. Russian Journal of Genetics: Applied Research 2(3): 252-259

Schnable JC, Freeling M, Lyons E (2012) Genome-Wide Analysis of Syntenic Gene Deletion in the Grasses. Genome Biology and Evolution 4(3): 265-277

Sede S, Escobar A, Morrone O, Zuloaga FO (2010) Chromosome studies in American Paniceae (Poaceae-Panicoideae). Annals of the Missouri Botanical Garden 97: 128-138

Silva AS, Villarroel D, Ribeiro ARO, Oliveira RC (2016) Eleven new records of little known taxa of Mesosetum and Paspalum (Poaceae) from Brazil and Bolivia. Phytotaxa 268(1): 069-079

Silva AS (dados não publicados) Filogenia de Mesosetum Steud. (Paspaleae: Poaceae) com base caracteres moleculares. Tese de Doutorado, Universidade de Brasília, Brasília-DF, Brazil

Silva LAC (2008) Qualidade de sementes da grama-do-cerrado (Mesosetum chaseae Luces) na subregião da Nhecolândia, Pantanal, MS. Dissertação de Mestrado, Universidade Estadual Paulista, Botucatu-SP, Brazil

Silva LAC, Pagliarini MS, Santos SA, Silva N, Souza VF (2012) Chromosome number, microsporogenesis, microgametogenesis, and pollen viability in the Brazilian native grass Mesosetum chaseae (Poaceae). Genetics and Molecular Research 11(4): 41004109 
Soreng RJ, Peterson PM, Romaschenko K, Davidse G, Zuloaga FO, Judziewicz EJ, Filgueiras TS, Davis JI, Morrone O (2015) A worldwide phylogenetic classification of the Poaceae (Gramineae). Journal of Systematics and Evolution 53(2): 117-137

Sousa MWS (2014) Citogenética e morfologia de espécies de Mesosetum Steud. (Poaceae, Paspaleae). Dissertação de Mestrado, Universidade de Brasília, Brasília-DF, Brazil

Studer AJ, Schnable JC, Weissmann S, Kolbe AR, McKain MR, Shao Y, Cousins AB, Kellogg EA, Brutnell TP (2016) The draft genome of the C3 panicoid grass species Dichanthelium oligosanthes. Genome Biology 17(223): 1-18

Swallen JR (1937) The grass genus Mesosetum. Brittonia 2(4): 363-392

Wang X, Wang J, Jin D, Guo H, Lee T-H, Liu T, Paterson AH (2015) Genome Alignment Spanning Major Poaceae Lineages Reveals Heterogeneous Evolutionary Rates and Alters Inferred Dates for Key Evolutionary Events. Molecular Plant 8: 885-898

Watson L, Dallwitz MJ (2016) The families of flowering plants: descriptions, illustrations, identification, and information retrieva 1992-onwards. Gramineae. Version 19 Oct. 2016. Available at: http://delta-intkey.com/angio/www/graminea.htm, Accessed 01 Nov. 2016

Zhao Y, Tang L, Li Z, Jin J, Luo J, Gao G (2015) Identification and analysis of unitary loss of longestablished protein-coding genes in Poaceae shows evidences for biased gene loss and putatively functional transcription of relics. BMC Evolutionary Biology 15(66): 210 


\section{CAPÍtULO 1}

Estudos cromossômicos em espécies de Mesosetum Steud. (Poaceae: Paspaleae) e gêneros relacionados 


\subsection{Introdução}

Panicoideae é a subfamília mais diversa na região tropical com cerca de 3500 espécies (GPWG 2001; Soreng et al. 2015; Burke et al. 2016). A evolução do genoma das espécies de Panicoideae está diretamente relacionada a eventos de aumento seguidos de redução do número cromossômico por meio de alopoliploidia, autopoliploidia e rearranjos no cariótipo (Hilu 2004; Parteson et al. 2004; Murat et al. 2010; Wang et al. 2015; Zhao et al. 2015; Studer et al. 2016).

Embora $\mathrm{x}=5, \mathrm{x}=9$ e $\mathrm{x}=10$ sejam os números cromossômicos predominantes em Panicoideae, são reportados números cromossômicos mais raros como $\mathrm{x}=3 \mathrm{e} \mathrm{x}=4$ (Celarier \& Paliwal 1957; Rao 1975; De Wet 1987; GPWG 2001; Hilu 2004; Goldblatt \& Johnson 2016). Os números básicos $x=3$ e $x=4(2 n=6$ e $2 n=8)$ são também os mais baixos já registrados entre as gramíneas tropicais, sendo reportados unicamente no gênero Iseilema Andersson (tribo Andropogoneae) e Mesosetum Steud. (tribo Paspaleae) (Celarier \& Paliwal 1957; Rao 1975; De Wet 1987; Morrone et al. 2012; Ribeiro 2013; Sousa 2014; Ribeiro et al. 2015). Em Mesosetum, a origem de $\mathrm{x}=4$ ainda é desconhecida (Ribeiro 2013; Sousa 2014; Ribeiro et al. 2015).

O gênero Mesosetum foi posicionado na tribo Paspaleae, subtribo Arthropogoninae na última filogenia da tribo Paniceae s.l. (Morrone et al. 2012). A tribo Paspaleae engloba espécies americanas que compõe um clado com número cromossômico básico $\mathrm{x}=10$ (Morrone et al. 2012).

A subtribo Arthropogoninae é composta por gêneros heterogêneos do ponto de vista morfológico, na qual Mesosetum tem maior diversidade de espécies (Filgueiras 1986, 1989; Morrone et al. 2012; Filgueiras et al. 2016). Dentro de Arthropogoninae, Mesosetum compõe um clado altamente suportado com os gêneros monoespecíficos Keratochlaena Morrone e Tatianyx Zuloaga \& Soderstr. (Morrone et al. 2012). 
A maioria dos gêneros de Arhtropogoninae possui registro de números cromossômicos múltiplos de $\mathrm{x}=10$, que também é o número cromossômico básico da tribo Paspaleae (Morrone et al. 2012). Entretanto, estas informações ainda são restritas a Homolepis aturensis (Kunth) Chase $(2 \mathrm{n}=20)$, H. isocalycia (G. Mey.) Chase $(2 \mathrm{n}=40)$, Phanopyrum gymnocarpon (Elliott) Nash $(2 \mathrm{n}=40)$ e Tatianyx arnacites (Trin.) Zuloaga \& Soderstr. $(2 \mathrm{n}=60)$ (Gould \& Soderstrom 1967; Pohl \& Davidse 1971; Kessler \& Hatch 1984; Morrone et al. 1995).

O gênero Mesosetum é o único gênero de Arthropogoninae que possui representantes com números cromossômicos básicos diferentes de $\mathrm{x}=10$. As primeiras informações sugeriam número básico $\mathrm{x}=8$ para o gênero e eram restritas a três espécies: Mesosetum chaseae Luces $(2 \mathrm{n}=16)$, M. loliiforme (Hochst. ex Steud.) Chase $(2 \mathrm{n}=16$ e 32$)$ e M. pittieri Hitchc. (Gould 1966; Gould \& Soderstrom 1967; Pohl \& Davidse 1971; Davidse \& Pohl 1972; Sede et al. 2010; Silva et al. 2012).

Estudos com enfoque citotaxonômico no gênero Mesosetum ampliaram o conhecimento acerca do número cromossômico para 13 espécies (Ribeiro 2013; Sousa 2014; Ribeiro et al. 2015). Os novos dados revelaram a ocorrência de mais dois números cromossômicos básicos em Mesosetum ( $\mathrm{x}=4$ e $\mathrm{x}=10)$ associados a dois grupos distintos de espécies.

O número cromossômico básico $\mathrm{x}=10$ foi observado nas espécies de Mesosetum sect. Mesosetum, as quais formam um grupo reconhecido morfologicamente pela presença de pelos ferrugíneos nas espiguetas (Swallen 1937; Filgueiras 1986, 1989; Sousa 2014). O número básico $\mathrm{x}=10$ foi encontrado em M. cayennense Steud. $(2 \mathrm{n}=20)$ e M. rottboellioides (Kunth) Hitchc. $(2 \mathrm{n}=20)$ e comprovado pelo pareamento em 10 bivalentes (Sousa 2014). Em $M$. ferrugineum var. ferrugineum (Trin.) Chase foi registrado número cromossômico $2 \mathrm{n}=60$, também múltiplo de $\mathrm{x}=10$, sugerindo hexaploidia. A ocorrência de $\mathrm{x}=10$ evidencia a 
relação de Mesosetum com outros gêneros de Arthropogoninae e corrobora os dados moleculares da filogenia de Paspaleae (Morrone et al. 2012).

$\mathrm{O}$ número cromossômico $2 \mathrm{n}=8(\mathrm{x}=4)$, também encontrado em Mesosetum, é o menor já registrado entre as gramíneas neotropicais (Ribeiro 2013, Sousa 2014; Ribeiro et al. 2015). Este número foi observado em quatro espécies: M. alatum Filg., M. annuum Swallen, M. ansatum (Trin.) Kuhlm. e M. longiaristatum Filg. (Ribeiro 2013, Sousa 2014; Ribeiro et al. 2015). O pareamento em quatro bivalentes sugeriu nível diploide para $2 \mathrm{n}=8$ e comprovou a ocorrência de $\mathrm{x}=4$ em Mesosetum (Ribeiro 2013, Sousa 2014; Ribeiro et al. 2015).

A poliploidia também parece ter atuado na evolução das espécies com $\mathrm{x}=4$ (Ribeiro 2013, Sousa 2014; Ribeiro et al. 2015). A presença de tetravalentes na meiose de M. bifarium (Hack.) Chase com $2 \mathrm{n}=16$ cromossomos, embora tenha sido observada em menos de $10 \%$ das diacineses, sugeriu tetraploidia e que $\mathrm{x}=8$ é na verdade um número cromossômico básico secundário derivado a partir de $\mathrm{x}=4$ por poliploidia. Além de plantas com $2 \mathrm{n}=16$, foram observados tetravalentes e associações múltiplas de cromossomos em espécies com 2 n $=24$ e $2 n=32$, sugerindo a ocorrência de hexaploidia e octaploidia no grupo de espécies com $\mathrm{x}=4$ (Ribeiro 2013, Sousa 2014).

As espécies com números cromossômicos múltiplos de $\mathrm{x}=4$, incluindo todos os níveis de ploidia $(2 \mathrm{n}=8,2 \mathrm{n}=16,2 \mathrm{n}=24$ e $2 \mathrm{n}=32)$, estão dispersas em três seções de Mesosetum: Bifaria (Hack.) Chase, Loliiformia Swallen e Sclerochloae Swallen (Filgueiras 1986, 1989). O grupo formado pela união destas três seções é bastante polimórfico e a ausência de pelos ferrugíneos é o único caractere morfológico que destingue o grupo com x = 4 do grupo $\operatorname{com} x=10$.

De acordo com a filogenia de Mesosetum baseada em caracteres moleculares (Silva dados não publicados), é possível reconhecer pelo menos dois clados bem suportados em Mesosetum, um formado pelas espécies com $\mathrm{x}=10$ e outro com $\mathrm{x}=4$. As espécies $M$. 
exaratum (Trin.) Chase e M. agropyroides Mez são linhagens monoespecíficas cujos números cromossômicos ainda são desconhecidos. M. exaratum é mais estritamente relacionada ao clado com $\mathrm{x}=10$, enquanto $M$. agropyroides é mais estritamente relacionada ao clado com $\mathrm{x}=$ 4.

A origem de $\mathrm{x}=4$ a partir de $\mathrm{x}=10$ representa a maior redução de número cromossômico já reportada na tribo Paspaleae e ainda não foi elucidada. A ausência de informações sobre o número cromossômico de $M$. exaratum, $M$. agropyroides e outras espécies impossibilita avaliar como as mudanças no cariótipo afetaram a evolução do genoma das espécies de Mesosetum.

Uma ampla caracterização citogenética de Mesosetum, incluindo contagens cromossômicas na maioria das suas espécies, como também de outros gêneros de Arthropogoninae e Paspaleae, são fundamentais para o fornecimento de parâmetros para a reconstrução da história evolutiva de Mesosetum e constituem-se no principal objetivo do primeiro capítulo desta tese.

\subsection{Material e Métodos}

\section{Contagens cromossômicas}

Foram realizadas expedições para diferentes regiões do Brasil com o objetivo de obter inflorescências fixadas para meiose, vouchers de herbário e plantas vivas para realizar os estudos de citogenéticos. As mudas foram obtidas de touceiras e estão sendo cultivadas na casa de vegetação da Universidade de Brasília.

As expedições foram planejadas com base nos dados da revisão de herbários nacionais e internacionais B, BAA, BM, CAY, CEN, CPAP, ESA, F, G, HB, HEPH, HRB, HUEFS, HUTO, IAN, IBGE, ICN, IPA, K, LE, MG, MHS, MO, MOSS, NX, P, PAMG, R, RB, S, SP, SP, UB, UEC, UFMT, UFRN, US e VEM (acrônimos disponíveis em Thiers 2016), além da 
base de dados do SpeciesLink (2016) para determinação tanto dos locais quanto das épocas de florescimento das espécies.

Foram realizadas coletas no Distrito Federal e estados do Amazonas, Bahia, Goiás, Mato Grosso, Minas Gerais, Pará, Pernambuco e Tocantins, entre novembro de 2013 e fevereiro de 2016.

Para análise da meiose as técnicas se basearam em Souza et al. (2012). As inflorescências coletadas no campo ou a partir do florescimento das mudas cultivadas, foram fixadas e armazenadas a $4^{\circ} \mathrm{C}$ em solução 3:1 (etanol:ácido acético, v/v). A coloração foi feita com carmim-acético $2 \%$ e os cromossomos foram observados e fotografados em Microscópio LEICA na Universidade de Brasília.

Para a mitose, as pontas de raízes foram coletadas a partir do material cultivado. Foram pré-tratadas com solução antimitótica de 8 -hidroxiquinoleina $2 \mathrm{mM}$ por $20 \mathrm{~h} \mathrm{a} 10^{\circ} \mathrm{C}$ e fixadas em solução Carnoy 3:1 (etanol:ácido acético, v/v) em temperatura ambiente por pelo menos $2 \mathrm{~h}$ e depois armazenadas a $4^{\circ} \mathrm{C}$. O meristema foi previamente amolecido com enzima pectinase-celulase $20-2 \%$ por 90 min a $37{ }^{\circ} \mathrm{C}$. As lâminas foram preparadas com ácido acético $60 \%$ e selecionadas sob microscopia em contraste de fase do Microscópio LEICA para serem coradas. As lâminas com pelo menos 5 metáfases espalhadas permitindo a distinção dos cromossomos foram coradas com solução DAPI-glicerol $1 / \mathrm{mL}$ e observadas em Microscópio com Epifluorescência LEICA no Laboratório de Citogenética da Universidade Federal de Pernambuco - UFPE. Os cromossomos em metáfases mitóticas foram medidos em pelo menos 5 células para estimar o tamanho mínimo e máximo dos cromossomos com auxílio do software LEICA Application Suite 4.5. 


\section{Dupla coloração CMA-DAPI}

Foi realizada dupla coloração nas melhores lâminas selecionadas de sete espécies de Mesosetum para caracterização da heterocromatina (Tabela 1), alguns acessos com número cromossômico já registrado em trabalhos anteriores (Ribeiro 2013, Sousa 2014, Ribeiro et al. 2015). A técnica foi realizada de acordo com o protocolo de Guerra \& Souza (2002).

Tabela 1. Espécies de Mesosetum com metáfases mitóticas avaliadas em dupla coloração com CMA-DAPI

\begin{tabular}{|c|c|c|}
\hline Espécie & Acesso & Local de Coleta \\
\hline Mesosetum ansatum (Trin.) Kuhlm. & RCO 2766* & $\begin{array}{l}\text { Brasil, Mato Grosso, } \\
\text { Poconé }\end{array}$ \\
\hline Mesosetum bifarium (Hack.) Chase & V 15933 & $\begin{array}{l}\text { Brasil, Goiás, Flores de } \\
\text { Goiás }\end{array}$ \\
\hline Mesosetum cayennense Steud. & AROR 362 & Brasil, Goiás, Pirenópolis \\
\hline Mesosetum compressum Swallen & ASS 274 & $\begin{array}{l}\text { Brasil, } \\
\text { Pesqueira }\end{array}$ \\
\hline Mesosetum exaratum (Trin.) Chase & AROR 351 & $\begin{array}{l}\text { Brasil, Minas Gerais, } \\
\text { Serra do Cipó }\end{array}$ \\
\hline Mesosetum ferrugineum var. setaceum Filg. & AROR 409 & $\begin{array}{l}\text { Brasil, Bahia, Rio de } \\
\text { Contas }\end{array}$ \\
\hline Mesosetum rottboellioides (Kunth) Hitchc. & PAR 331* & $\begin{array}{l}\text { Brasil. Minas Gerais, } \\
\text { Grão Mogol }\end{array}$ \\
\hline
\end{tabular}

* Acesso com número cromossômico já determinado em trabalho anterior.

As lâminas prontas e secas foram coradas com 8 de $\mu \mathrm{L}$ CMA (cromomicina A3) em solução a $0,5 \mathrm{mg} / \mathrm{mL}$ por $1 \mathrm{~h}$. Após a coloração com CMA as lamínulas foram removidas com jato de água e secas ao ar. Depois de secas, as lâminas foram coradas com $8 \mu$ L DAPI (4'6'diamidino - 2' - fenilindol) em solução a $2 \mu \mathrm{g} / \mathrm{ml}$ por 30 minutos. Após a coloração com DAPI, as lamínulas foram novamente removidas com jato de água e secas aos ar. Depois de secas as lâminas foram montadas com meio de montagem glicerol-Mcllvaine e guardadas no escuro por pelo menos 3 dias até a análise (Guerra \& Souza 2002).

Após a dupla coloração, as lâminas foram examinadas em Microscópio com Epifluorescência LEICA no Laboratório de Citogenética da Universidade Federal de Pernambuco - UFPE. 
Os números cromossômicos de 18 acessos foram aqui determinados incluindo 13 espécies de Paspaleae, sendo 12 espécies da subtribo Arthropogoninae e uma da subtribo Paspalinae (Tabela 2, Figuras 1, 2 e 3). Entre os gêneros de Arthropogoninae, o número cromossômico foi determinado em uma espécie de Arthropogon Nees, 10 espécies de Mesosetum e uma de Tatianyx (Tabela 2). Na Subtribo Paspalinae, o número cromossômico foi determinado para uma espécie do gênero Spheneria Kuhlm. (Tabela 2).

Em sete espécies o número cromossômico foi registrado pela primeira vez: Arthropogon villosus Nees $(2 \mathrm{n}=40)$, Mesosetum chlorostachyum (Döll) Chase $(2 \mathrm{n}=8), M$. compressum Swallen $(2 \mathrm{n}=16)$, M. exaratum (Trin.) Chase $(2 \mathrm{n}=26)$, . gibbosum Renvoize \& Filg. $(2 \mathrm{n}=24)$, M. pappophorum (Nees) Kuhlm. $(2 \mathrm{n}=8)$ e Spheneria kegelii (Müll. Hal.) Pilg. $(2 n=20)$.

Novos citótipos foram encontrados para M. bifarium $(2 \mathrm{n}=8)$ em plantas coletadas no município de Flores de Goiás-GO e M. ferrugineum var. setaceum Filg. $(2 \mathrm{n}=20)$ em plantas coletadas em Rio de Contas-BA (Tabela 2, Figuras 1 e 2).

Os cromossomos de Tatianyx arnacites (Trin.) Zuloaga \& Soderstr. $(2 \mathrm{n}=60)$ foram pela primeira vez observados em mitose (Figura 2) e confirmaram a contagem anterior em outro acesso feita em meiose por Morrone et al. (1995).

As contagens em M. bifarium $(2 \mathrm{n}=16)$, M. cayennense Steud. $(2 \mathrm{n}=20), M$. elytrochaetum (Hack.) Swallen $(2 \mathrm{n}=24)$ e M. sclerochloa (Trin.) Hitchc. $(2 \mathrm{n}=16)$ confirmaram, em novas populações, os números cromossômicos previamente reportados por Ribeiro (2013) e Souza (2014) (Tabela 2).

Para facilitar a interpretação e discussão dos resultados, os dados de número cromossômico do presente capítulo somados aos dados de trabalhos anteriores (Gould 1966; Gould \& Soderstrom 1967; Pohl \& Davidse 1971; Davidse \& Pohl 1972; Sede et al. 2010; 
Silva et al. 2012; Ribeiro 2013; Souza 2014; Ribeiro et al. 2015) foram plotados na filogenia molecular proposta por Silva (dados não publicados) (Figura 4).

Tabela 2. Números cromossômicos observados em espécies de Arthropogoninae e Paspalinae

\begin{tabular}{|c|c|c|c|}
\hline Espécie & Acesso & $\begin{array}{c}\text { Número } \\
\text { Cromossômico }\end{array}$ & Local de Coleta \\
\hline $\begin{array}{l}\text { Arthropogon villosus } \\
\text { Nees }\end{array}$ & RCO 2969 & $2 n=40$ & $\begin{array}{l}\text { Brasil, Distrito Federal, } \\
\text { Brasília }\end{array}$ \\
\hline $\begin{array}{l}\text { Arthropogon villosus } \\
\text { Nees }\end{array}$ & RCO 2971 & $2 n=40$ & $\begin{array}{l}\text { Brasil, Distrito Federal, } \\
\text { Brasília }\end{array}$ \\
\hline $\begin{array}{l}\text { Mesosetum bifarium } \\
\text { (Hack.) Chase }\end{array}$ & V 15927 & $2 n=8$ & $\begin{array}{l}\text { Brasil, Goiás, Flores de } \\
\text { Goiás }\end{array}$ \\
\hline $\begin{array}{l}\text { Mesosetum bifarium } \\
\text { (Hack.) Chase }\end{array}$ & V 15933 & $2 \mathrm{n}=8$ & $\begin{array}{l}\text { Brasil, Goiás, Flores de } \\
\text { Goiás }\end{array}$ \\
\hline $\begin{array}{l}\text { Mesosetum bifarium } \\
\text { (Hack.) Chase }\end{array}$ & AROR 391 & $2 n=16$ & Brasil, Goiás, Alto Paraíso \\
\hline $\begin{array}{l}\text { Mesosetum cayennense } \\
\text { Steud. }\end{array}$ & PAR 181 & $2 n=20$ & $\begin{array}{l}\text { Brasil, Goiás, Flores de } \\
\text { Goiás }\end{array}$ \\
\hline $\begin{array}{l}\text { Mesosetum cayennense } \\
\text { Steud. }\end{array}$ & AROR 362 & $2 n=20$ & Brasil, Goiás, Pirenópolis \\
\hline $\begin{array}{l}\text { Mesosetum cayennense } \\
\text { Steud. }\end{array}$ & RCO 2848 & $2 n=20$ & $\begin{array}{l}\text { Brasil, } \\
\text { Natividade }\end{array}$ \\
\hline $\begin{array}{l}\text { Mesosetum } \\
\text { chlorostachyum (Döll) } \\
\text { Chase }\end{array}$ & RCO 3033 & $2 n=8$ & Brasil, Amazonas, Manaus \\
\hline $\begin{array}{l}\text { Mesosetum compressum } \\
\text { Swallen }\end{array}$ & ASS 274 & $2 n=16$ & $\begin{array}{l}\text { Brasil, } \quad \text { Pernambuco, } \\
\text { Pesqueira }\end{array}$ \\
\hline $\begin{array}{l}\text { Mesosetum elytrochaetum } \\
\text { (Hack.) Swallen }\end{array}$ & AROR 377 & $2 n=24$ & Brasil, Goiás, Alto Paraíso \\
\hline $\begin{array}{l}\text { Mesosetum exaratum } \\
\text { (Trin.) Chase }\end{array}$ & AROR 351 & $2 n=26$ & $\begin{array}{l}\text { Brasil, Minas Gerais, Serra } \\
\text { do Cipó }\end{array}$ \\
\hline $\begin{array}{l}\text { Mesosetum ferrugineum } \\
\text { var. setaceum Filg. }\end{array}$ & AROR 409 & $2 n=20$ & $\begin{array}{l}\text { Brasil, Bahia, Rio de } \\
\text { Contas }\end{array}$ \\
\hline $\begin{array}{l}\text { Mesosetum gibbosum } \\
\text { Renvoize \& Filg. }\end{array}$ & AROR 408 & $2 n=24$ & $\begin{array}{l}\text { Brasil, Bahia, Rio de } \\
\text { Contas }\end{array}$ \\
\hline $\begin{array}{l}\text { Mesosetum pappophorum } \\
\text { (Nees) Kuhlm. }\end{array}$ & V 15949 & $2 n=8$ & $\begin{array}{l}\text { Brasil, Goiás, Flores de } \\
\text { Goiás }\end{array}$ \\
\hline $\begin{array}{l}\text { Mesosetum sclerochloa } \\
\text { (Trin.) Hitchc. }\end{array}$ & V 15937 & $2 n=16$ & $\begin{array}{l}\text { Brasil, Goiás, Flores de } \\
\text { Goiás }\end{array}$ \\
\hline $\begin{array}{l}\text { Spheneria kegelii (Müll. } \\
\text { Hal.) Pilg. }\end{array}$ & RCO 3007 & $2 n=20$ & Brasil, Amazonas, Manaus \\
\hline
\end{tabular}




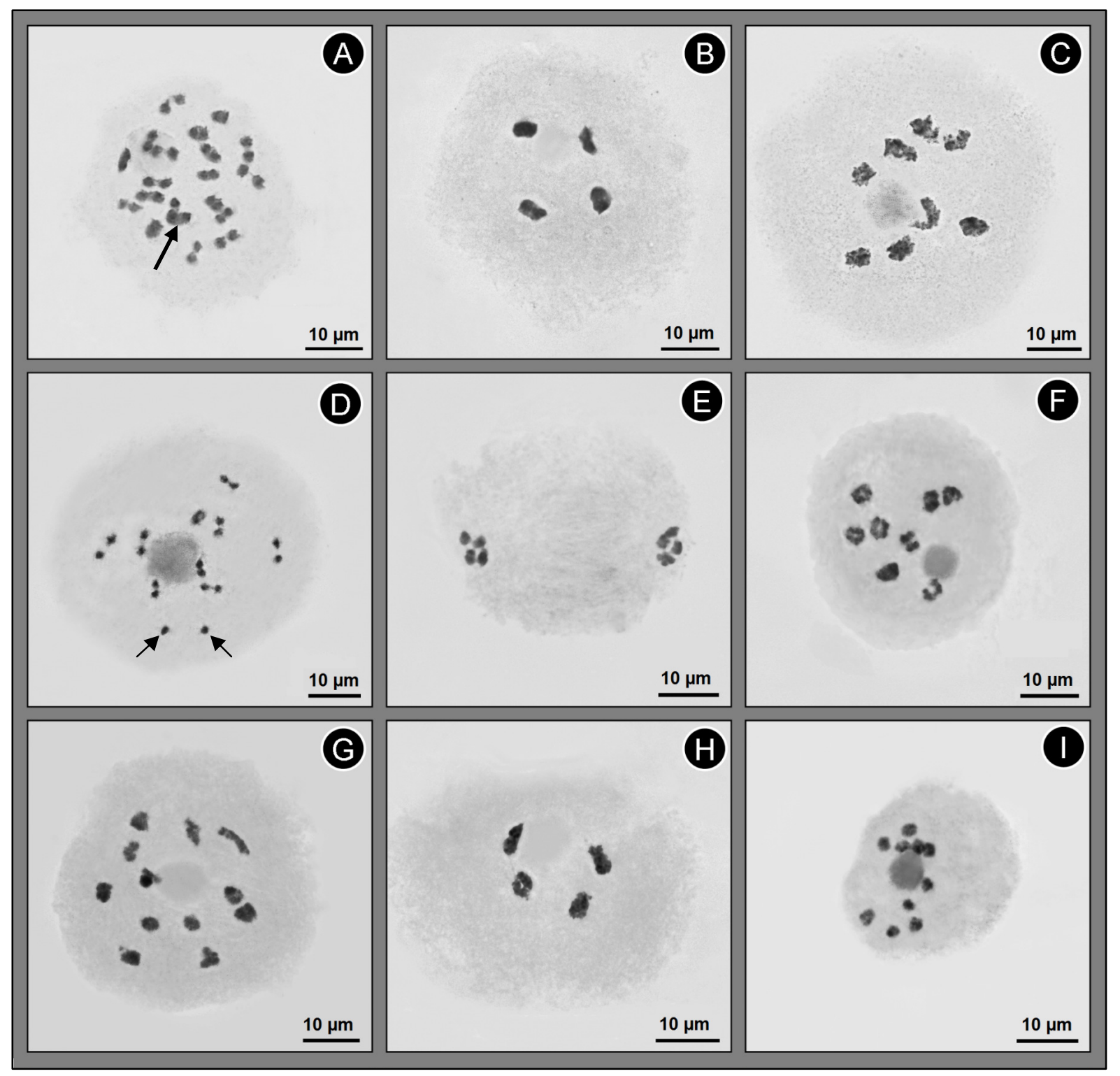

Figura 1. Células em meiose mostrando os cromossomos de espécies de Arthropogoninae e Paspalinae. A. Arthropogon villosus, RCO 2971, diacinese com 20 bivalentes (seta indica dois bivalentes sobrepostos). B-C. Mesosetum bifarium B. diploide $(2 \mathrm{n}=8)$, V 15933, diacinese com quatro bivalentes. C. tetraploide $(2 \mathrm{n}=16)$, AROR 391, diacinese com 8 bivalentes. D. $M$. cayennense, RCO 2848, diacinese com 9 bivalentes e dois univalentes (setas). E. $M$. chlorostachyum, RCO 3033, anáfase I, quatro cromossomos em cada polo. F. $M$. compressum, ASS 274, diacinese com oito bivalentes. G. $M$. gibbosum, AROR 408, diacinese com 12 bivalentes. H. M. pappophorum, V 15949, diacinese com quatro bivalentes. I. Spheneria kegelii, RCO 3007, diacinese com 10 bivalentes. 


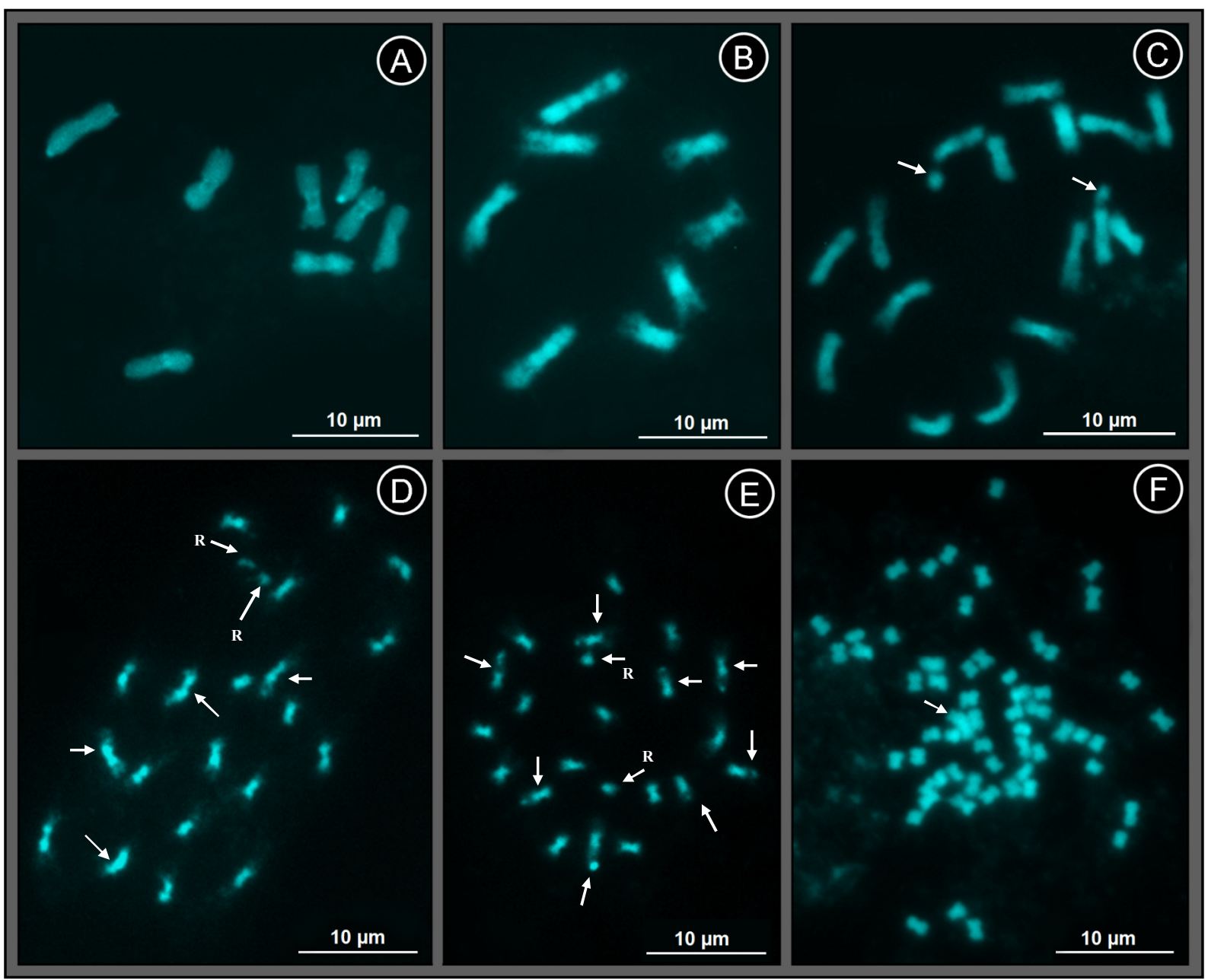

Figura 2. Células em mitose coradas com DAPI mostrando os cromossomos de espécies de Arthropogoninae. A-C. Espécies com número cromossômico básico x $=4$. A. Mesosetum ansatum $(2 \mathrm{n}=8)$, RCO 2766. B. M. bifarium $(2 \mathrm{n}=8)$, V 15933. C. $M$. compressum $(2 \mathrm{n}=$ 16), ASS 274, com região organizadora do nucléolo (RON) distendida e satélites evidentes (setas). D-F. Espécies com número cromossômico básico $\mathrm{x}=10$. D. M. cayennense $(2 \mathrm{n}=20)$, AROR 362, com RON distentida mostrando satélites isolados dos braços cromossômicos ( $\operatorname{setas} \mathrm{R})$, mais quatro cromossomos satelitados (setas). E. M. rottboellioides $(2 \mathrm{n}=20)$, PAR 331, com RON distendida mostrando satélites maiores isolados (setas R) dos braços cromossômicos, mais oito cromossomos satelitados (setas). F. Tatianyx arnacites, $(2 \mathrm{n}=60)$, AROR 411, seta indicando dois cromossomos sobrepostos. 


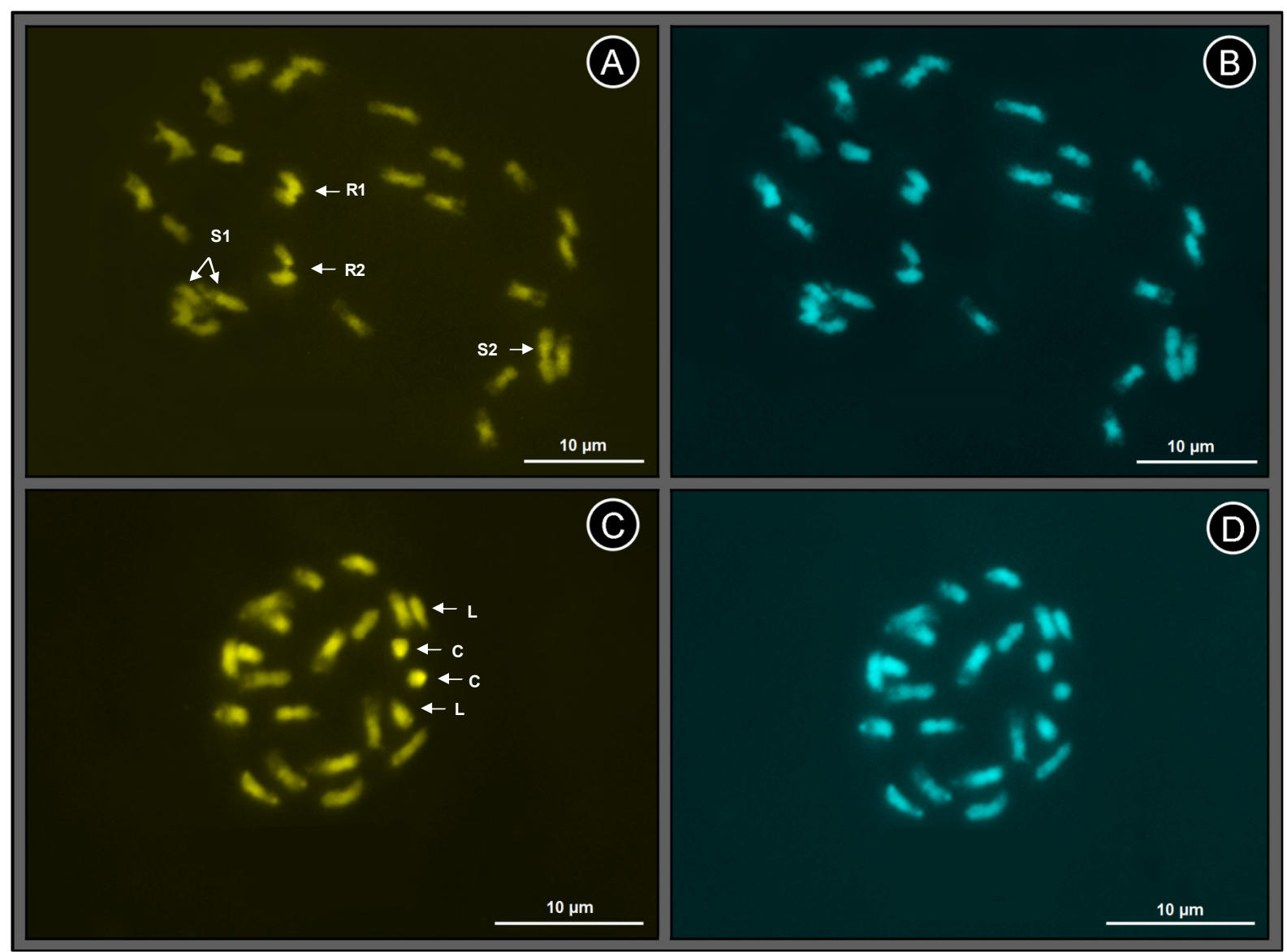

Figura 3. Metáfases mitóticas de espécies de Mesosetum com $\mathrm{x}=10$ e $\mathrm{x}=13$ coradas com CMA (amarelo) e DAPI (azul). A-B. Mesosetum exaratum $(2 \mathrm{n}=26)$, AROR 351, mostrando dois pares cromossômicos com instabilidade centromérica, o primeiro (R1 e R2) incluindo região organizadora do nucléolo (RON) e o segundo (S1 e S2) satelitado. A. Célula corada com CMA mostrando banda mais intensa localizada na RON situada na região centromérica (setas R1 e R2) levemente distendida em um dos cromossomos (R2); um dos cromossomos satelitados também está com o centrômero distendido (S1). B. Mesma célula corada com DAPI. C-D. M. ferrugineum var. setaceum $(2 \mathrm{n}=20)$, AROR 409 , mostrando um par cromossômico com instabilidade centromérica. C. Célula corada com CMA mostrando banda intensa na RON localizada no fragmento proveniente do braço curto (C) e dois fragmentos provenientes do braço longo (L), sendo possível identificar mais pelo menos 10 cromossomos satelitados. D. Mesma célula corada com DAPI. 


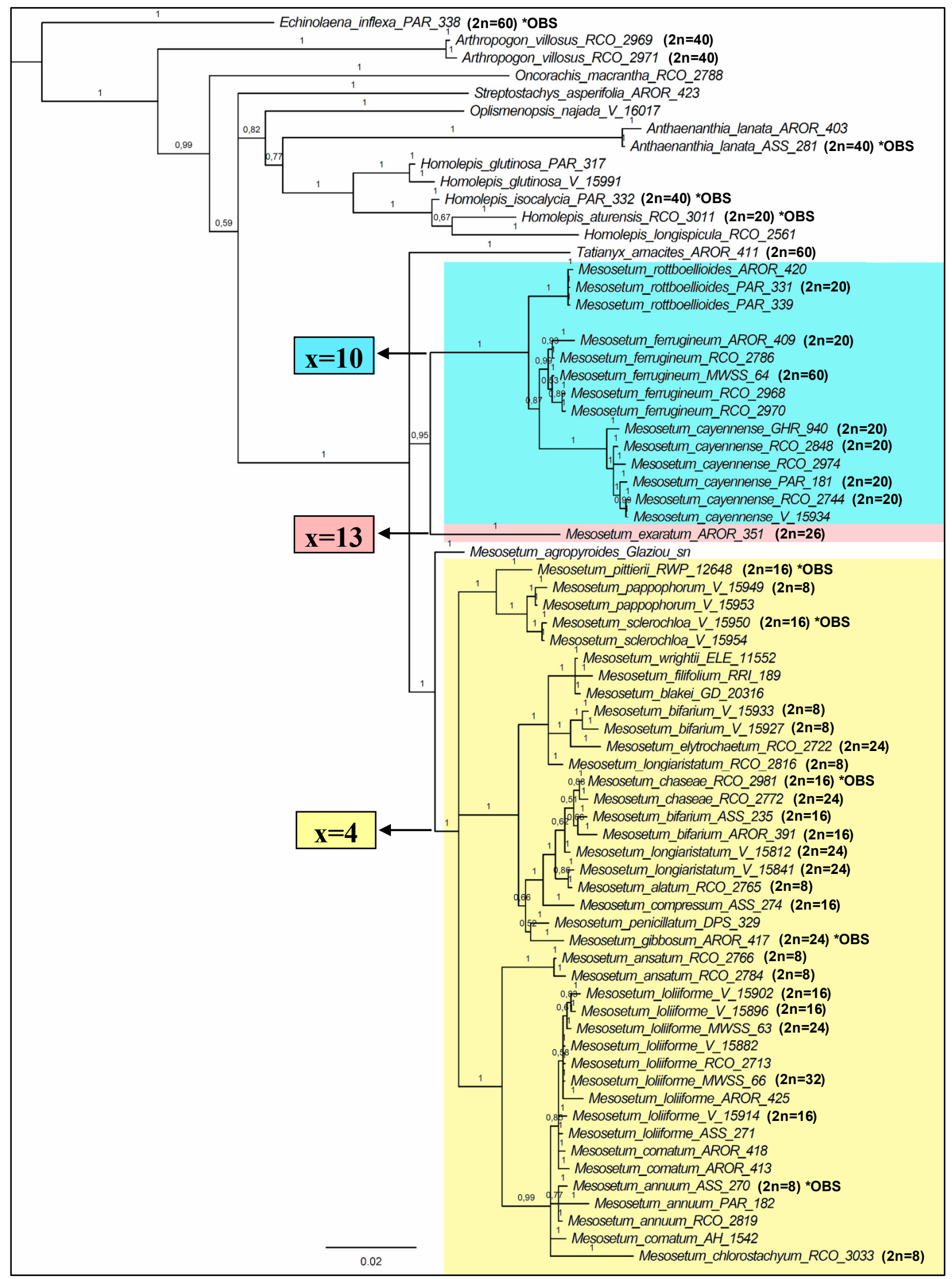

Figura 4. Dados de número cromossômico do presente trabalho enriquecidos por revisão de literatura e plotados na árvore filogenética das espécies de Mesosetum elaborada por Silva (dados não publicados) baseada em análise bayesiana combinada dos marcadores ITS, trnLF, psbA-trnH e matK. *OBS: Número cromossômico encontrado para mesma espécie, porém em acesso diferente do utilizado na árvore filogenética. 


\section{Morfologia dos cromossomos em mitose}

Os cromossomos mitóticos corados com DAPI mostraram bandas intensas nas regiões centroméricas e pericentroméricas de todas as espécies examinadas com $\mathrm{x}=4, \mathrm{x}=10$ e $\mathrm{x}=13$ (Figuras 2 e 3). Alguns cromossomos também mostraram bandas de DAPI terminais (Figuras 2 e 3). Todas as bandas DAPI centroméricas e terminais também coraram intensamente com CMA (Figura 3) indicando que a heterocromatina AT e GC repetitiva estão colocalizadas nestas regiões cromossômicas.

Já a região organizadora do nucléolo (RON) mostrou banda mais intensa somente com CMA (Figura 3) em M. cayennense $(2 \mathrm{n}=20), M$. compressum $(2 \mathrm{n}=16)$, . exaratum $(2 \mathrm{n}=$ 26), M. ferrugineum var. setaceum $(2 \mathrm{n}=20)$ e M. rottboellioides $(2 \mathrm{n}=20)$ (Figuras 2 e 3$)$. Em M. ansatum e M. bifarium não foi possível identificar a RON pela dupla coloração CMADAPI. Em M. exaratum e M. ferrugineum var. setaceum foram observados cromossomos com instabilidade centromérica (Figura 3).

Os cromossomos das espécies com $\mathrm{x}=10$ variaram entre $1,5-4,0 \mu \mathrm{m}$ de comprimento e foram os menores entre todas as espécies (Tabela 3). Entre as espécies com $\mathrm{x}=10$, os menores cromossomos foram encontrados em T. arnacites com comprimento variando entre 1,5-2,5 $\mu \mathrm{m}$. Entre as espécies de Mesosetum, os menores cromossomos foram encontrados em M. rottboellioides com comprimento variando entre 1,8-3,9 $\mu \mathrm{m}$. Foram encontrados cromossomos satelitados em todas as espécies de Mesosetum com $\mathrm{x}=10$, sendo seis pares satelitados em M. cayennense, 10 pares satelitados em M. ferrgineum var. setaceum, e 10 pares satelitados em $M$. rottboellioides. A RON está localizada no maior satélite em $M$. cayennense e M. rottboellioides. 
Tabela 3. Variação do tamanho cromossômico entre os cromossomos observados em metáfases mitóticas de espécies de Mesosetum e Tatianyx

\begin{tabular}{|c|c|c|c|}
\hline Espécie & Acesso & $\begin{array}{c}\text { Número } \\
\text { cromossômico }\end{array}$ & $\begin{array}{c}\text { Comprimento } \\
\text { cromossômico } \\
\text { mínimo e máximo }\end{array}$ \\
\hline $\begin{array}{l}\text { Mesosetum ansatum (Trin.) } \\
\text { Kuhlm. }\end{array}$ & RCO 2766 & $2 n=8$ & $5,1-6,8 \mu \mathrm{m}$ \\
\hline $\begin{array}{l}\text { Mesosetum bifarium (Hack.) } \\
\text { Chase }\end{array}$ & V 15933 & $2 n=8$ & $4,5-7,2 \mu \mathrm{m}$ \\
\hline $\begin{array}{l}\text { Mesosetum cayennense } \\
\text { Steud. }\end{array}$ & AROR 362 & $2 n=20$ & $2,3-4,0 \mu \mathrm{m}$ \\
\hline $\begin{array}{l}\text { Mesosetum compressum } \\
\text { Swallen }\end{array}$ & ASS 274 & $2 n=16$ & $3,7-6,3 \mu \mathrm{m}$ \\
\hline $\begin{array}{l}\text { Mesosetum ferrugineum var. } \\
\text { setaceum Filg. }\end{array}$ & AROR 409 & $2 n=20$ & $2,3-3,9 \mu \mathrm{m}$ \\
\hline $\begin{array}{l}\text { Mesosetum exaratum (Trin.) } \\
\text { Chase }\end{array}$ & AROR 351 & $2 n=26$ & $2,5-5,0 \mu \mathrm{m}$ \\
\hline $\begin{array}{l}\text { Mesosetum rottboellioides } \\
\text { (Kunth) Hitchc. }\end{array}$ & PAR 331 & $2 n=20$ & $1,8-3,9 \mu \mathrm{m}$ \\
\hline $\begin{array}{l}\text { Tatianyx arnacites (Trin.) } \\
\text { Zuloaga \& Soderstr. }\end{array}$ & AROR 411 & $2 n=60$ & $1,5-2,5 \mu \mathrm{m}$ \\
\hline
\end{tabular}

Em M. ferrugineum var. setaceum foi observada instabilidade centromérica em apenas 1 par, que não possui satélite e no qual a RON está localizada. Quando a RON está distendida, também há rompimento do centrômero, formando dois fragmentos, um proveniente do braço longo e outro proveniente do braço curto, o qual mantem a banda intensa de CMA (Figura 3 C-D).

Os maiores cromossomos foram observados nas espécies com $\mathrm{x}=4$, com cromossomos variando entre 3,7 e 7,2 $\mu \mathrm{m}$. Em M. bifarium foram encontrados os maiores cromossomos com comprimento variando entre 4,5 e 7,2 $\mu \mathrm{m}$. Em $M$. ansatum foram observados pequenos satélites em todos os cromossomos. Em M. compressum foi observado apenas um par satelitado.

Os cromossomos de $M$. exaratum com $\mathrm{x}=13$ tiveram comprimento variando entre 2,5 e 5,0 $\mu \mathrm{m}$ e um par satelitado foi observado (Figura 3). Em M. exaratum foram observados dois pares com instablidade centromérica, um deles contendo a RON, que quando está 
distendida rompre o centrômero originando dois fragmentos. O outro par com instabilidade centromérica corresponde ao par satelitado (Figura 3A-B).

\subsection{Discussão}

$\mathrm{O}$ número cromossômico $2 \mathrm{n}=26$ observado no presente trabalho em $M$. exaratum é pela primeira vez registrado na subfamília Panicoideae. A ocorrência do número cromossômico básico $\mathrm{x}=13$ é rara e citada somente para oito gêneros de Poaceae, dos quais seis pertencem à subfamília Pooideae, um a subfamília Aristidoideae e um a subfamília Chloridoideae (Tabela 4).

Tabela 4. Espécies de Poaceae com $2 \mathrm{n}=26$ cromossomos de acordo com a base de dados de Goldblatt \& Johnson (2016) e enriquecida com revisão de literatura da presente tese de doutorado

\begin{tabular}{|c|c|c|c|c|c|}
\hline Espécie & $\begin{array}{l}\text { Gam. } \\
\text { (n) }\end{array}$ & $\begin{array}{l}\text { Spor. } \\
(2 n)\end{array}$ & Subfamília* & Tribo* & Referência \\
\hline $\begin{array}{l}\text { Calamagrostis } \\
\text { sukatschewii (Popl.) } \\
\text { Roshev. }\end{array}$ & & 26 & Pooideae & Poeae & $\begin{array}{l}\text { Belaeva \& } \\
\text { Siplivinsky (1981) }\end{array}$ \\
\hline $\begin{array}{l}\text { Chaetium bromoides } \\
\text { (J. Presl) Benth. ex } \\
\text { Hemsl. }\end{array}$ & & 26 & Aristidoideae & Aristidae & $\begin{array}{l}\text { Pohl \& Davidse } \\
\text { (1971) }\end{array}$ \\
\hline $\begin{array}{l}\text { Deschampsia } \\
\text { antarctica Desv. }\end{array}$ & & 26 & Pooideae & Poeae & $\begin{array}{l}\text { Cardone et al. } \\
\text { (2009); Amosova et } \\
\text { al. (2015) }\end{array}$ \\
\hline $\begin{array}{l}\text { Deschampsia } \\
\text { argentea (Lowe) } \\
\text { Lowe }\end{array}$ & & 26 & Pooideae & Poeae & Dalgaard (1991) \\
\hline $\begin{array}{l}\text { Deschampsia } \\
\text { baicalensis Tzvelev }\end{array}$ & & 26 & Pooideae & Poeae & $\begin{array}{l}\text { Probatova et al. } \\
(2015)\end{array}$ \\
\hline $\begin{array}{l}\text { Deschampsia } \\
\text { borealis (Trautv.) } \\
\text { Roshev. }\end{array}$ & & 26 & Pooideae & Poeae & $\begin{array}{l}\text { Zhukova \& } \\
\text { Petrovsky (1980); } \\
\text { Petrovsky \& } \\
\text { Zhukova (1981); } \\
\text { Zhukova (1982) }\end{array}$ \\
\hline $\begin{array}{l}\text { Deschampsia } \\
\text { bottnica (Wahlenb.) } \\
\text { Trin. }\end{array}$ & & 26 & Pooideae & Poeae & Albers (1980) \\
\hline $\begin{array}{l}\text { Deschampsia } \\
\text { caespitosa (L.) P. } \\
\text { Beauv. }\end{array}$ & & 26 & Pooideae & Poeae & $\begin{array}{l}\text { Pashuk (1980); } \\
\text { Stoeva (1982); } \\
\text { Beuzenberg \& Hair } \\
\text { (1983); Strid \& } \\
\text { Franzen (1983) }\end{array}$ \\
\hline
\end{tabular}




\begin{tabular}{|c|c|c|c|c|}
\hline $\begin{array}{l}\text { Deschampsia } \\
\text { chapmanii Petrie }\end{array}$ & 26 & Pooideae & Poeae & Murray et al. (2005) \\
\hline $\begin{array}{l}\text { Deschampsia } \\
\text { flexuosa (L.) Trin. }\end{array}$ & 26 & Pooideae & Poeae & $\begin{array}{l}\text { Druskovic \& Lovka } \\
\text { (1995) }\end{array}$ \\
\hline $\begin{array}{l}\text { Deschampsia } \\
\text { gracillima Kirk }\end{array}$ & 26 & Pooideae & Poeae & Murray et al. (2005) \\
\hline $\begin{array}{l}\text { Deschampsia } \\
\text { komarovii V.N. } \\
\text { Vassil. }\end{array}$ & 26 & Pooideae & Poeae & $\begin{array}{l}\text { Zhukova (1980); } \\
\text { Petrovsky \& } \\
\text { Zhukova (1981); } \\
\text { Probatova et al. } \\
(2015)\end{array}$ \\
\hline $\begin{array}{l}\text { Deschampsia macrothyrsa } \\
\text { (Tatew. \& Ohwi) Kawano }\end{array}$ & 26 & Pooideae & Poeae & $\begin{array}{l}\text { Probatova (1984); } \\
\text { Probatova et al. } \\
(2015)\end{array}$ \\
\hline $\begin{array}{l}\text { Deschampsia media } \\
\text { (Gouan) Roem. \& } \\
\text { Schult. }\end{array}$ & 26 & Pooideae & Poeae & $\begin{array}{l}\text { Kerguelen (1975); } \\
\text { Albers (1980); } \\
\text { Garciá-Suárez et al. } \\
\text { (1997) }\end{array}$ \\
\hline $\begin{array}{l}\text { Deschampsia obensis } \\
\text { Roshev. }\end{array}$ & 26 & Pooideae & Poeae & $\begin{array}{l}\text { Probatova et al. } \\
\text { (2015) }\end{array}$ \\
\hline $\begin{array}{l}\text { Deschampsia } \\
\text { pamirica } \text { Roshev. }\end{array}$ & 26 & Pooideae & Poeae & $\begin{array}{l}\text { Probatova et al. } \\
(2015)\end{array}$ \\
\hline $\begin{array}{l}\text { Deschampsia } \\
\text { paramushirensis } \\
\text { Honda }\end{array}$ & 26 & Pooideae & Poeae & $\begin{array}{l}\text { Probatova et al. } \\
\text { (2015) }\end{array}$ \\
\hline $\begin{array}{l}\text { Deschampsia refracta } \\
\text { (Lagasca) Roem. \& Schult. }\end{array}$ & 26 & Pooideae & Poeae & Albers (1980) \\
\hline $\begin{array}{l}\text { Deschampsia } \\
\text { submutica (Trautv.) } \\
\text { O.D. Nikif. }\end{array}$ & 26 & Pooideae & Poeae & $\begin{array}{l}\text { Probatova et al. } \\
\text { (2015) }\end{array}$ \\
\hline $\begin{array}{l}\text { Deschampsia } \\
\text { sukatschewii (Popl.) } \\
\text { Roshev. }\end{array}$ & 26 & Pooideae & Poeae & $\begin{array}{l}\text { Probatova et al. } \\
\text { (2015) }\end{array}$ \\
\hline $\begin{array}{l}\text { Deschampsia tenella } \\
\text { Petrie }\end{array}$ & 26 & Pooideae & Poeae & Murray et al. (2005) \\
\hline $\begin{array}{l}\text { Deschampsia } \\
\text { tzvelevii Prob. }\end{array}$ & 26 & Pooideae & Poeae & $\begin{array}{l}\text { Probatova (1984); } \\
\text { Probatova (2004); } \\
\text { Probatova (2005) }\end{array}$ \\
\hline $\begin{array}{l}\text { Deschampsia } \\
\text { wibeliana (Sond. ex } \\
\text { Koch) Parl. }\end{array}$ & 26 & Pooideae & Poeae & Měsíček (1992) \\
\hline $\begin{array}{l}\text { Hainardia cylindrica } \\
\text { (Willd.) Greuter }\end{array}$ & & Pooideae & Poeae & $\begin{array}{l}\text { Devesa et al. (1990); } \\
\text { Cuccuini \& Fiurini } \\
\text { (2004) }\end{array}$ \\
\hline $\begin{array}{l}\text { Lophochloa phleoides } \\
\text { (Vill.) Rchb. }\end{array}$ & 26 & Pooideae & Poeae & $\begin{array}{l}\text { Ko|3zuharov \& } \\
\text { Petrova }(1991)\end{array}$ \\
\hline $\begin{array}{l}\text { Lophochloa pumila } \\
\text { (Desf.) Bor }\end{array}$ & & Pooideae & Poeae & $\begin{array}{l}\text { Devesa \& Zarco } \\
(1984)\end{array}$ \\
\hline
\end{tabular}


Arohonka (1982);

Ko|3zuharov \&

Petrova (1991);

Krahulcová (2003)

Orcuttia tenuis

26 Chloridoideae Cynodonteae Reeder(1982)

Hitchc.

Rostraria cristata

13

Pooideae

Poeae

Devesa et al. (1991)

(L.) Tzvelev

Gam.: número cromossômico observado em gametófito. Espor.: número cromossômico observado em esporófito. * As subfamílias e tribos estão de acordo com base de dados de USDA \& ARS (2016).

Em Arthropogoninae, as contagens obtidas pelo presente trabalho de $2 \mathrm{n}=40 \mathrm{em}$ Arthropogon villosus e $2 \mathrm{n}=60$ em Tatianyx arnacites (também citado por Morrone et al. 1995) aliadas aos registros de $2 \mathrm{n}=20 \mathrm{em}$ Homolepis aturensis, $2 \mathrm{n}=40 \mathrm{em} \mathrm{H}$. isocalycia e $2 \mathrm{n}$ = 40 em Phanopyrum gymnocarpon (Gould \& Soderstrom 1967; Pohl \& Davidse 1971; Kessler \& Hatch 1984) suportam $\mathrm{x}=10$ como número cromossômico básico da subtribo e corroboram os dados da filogenia proposta por Morrone et al. (2012) que atribuíram $\mathrm{x}=10$ como número cromossômico básico da tribo Paspaleae.

Em Mesosetum, os números cromossômicos reportados pelo presente trabalho reforçam os resultados obtidos por Ribeiro (2013), Sousa (2014), Ribeiro et al. (2015) e suportam os dois clados prospostos pela filogenia de Silva (dados não publicados), um com x $=10$ representado por três espécies, o outro com $\mathrm{x}=4$ representado por 20 espécies, 14 das quais com número cromossômico conhecido. O número cromossômico básico $\mathrm{x}=13$ também suporta a linhagem monoespecífica de M. exaratum na filogenia proposta por Silva (dados não publicados) e não foi observado em nenhuma outra espécie de Mesosetum. A linhagem monoespecífica de M. agropyroides permanece com número cromossômico desconhecido.

O clado com número cromossômico básico $\mathrm{x}=10(2 \mathrm{n}=20$ e $2 \mathrm{n}=60)$ é provavelmente o mais basal em Mesosetum (Silva dados não publicados) e também o mais relacionado citologicamente aos gêneros irmãos pertencentes à subtribo Arthropogoninae e tribo Paspaleae, os quais também possuem números cromossômicos múltiplos de $\mathrm{x}=10$. Este 
clado provavelmente conserva um cariótipo mais próximo ao ancestral de Mesosetum e ao ancestral da subfamília Panicoideae cuja maioria dos registros de números cromossômicos é de $2 n=20(x=10)$ com cromossomos pequenos entre 1,0 e $4,5 \mu \mathrm{m}$ e genoma de tamanho reduzido com valor modal de quantidade de DNA por cromossomo $(2 \mathrm{C} / 2 \mathrm{n})$ igual a $0,1 \mathrm{pg}$ (Morrone et al. 1995; Price et al. 2005; Morrone et al. 2006; Hidalgo et al. 2007; Sede et al. 2010; Leitch et al. 2010; Pozzobon et al. 2013; Bernardo Filho et al. 2014).

Em Mesosetum, o clado $\mathrm{x}=10$ é representado pelas espécies $M$. cayennense $(2 \mathrm{n}=20)$, a espécie tipo do gênero, M. ferrugineum $(2 \mathrm{n}=20$ e $2 \mathrm{n}=60)$ e M. rottboelioides $(2 \mathrm{n}=20)$. Essas espécies foram tratadas como Mesosetum sect. Fulva por Swallen (1937), a qual foi aceita, mas renomeada como Mesosetum sect. Mesosetum por Filgueiras (1986, 1989), por conter a espécie tipo. O tamanho reduzido dos cromossomos entre 1,8 e 4,0 $\mu \mathrm{m}$ é uma característica compartilhada pelas espécies do clado $\mathrm{x}=10$, intervalo o qual está inserido dentro do tamanho cromossômico da maioria das espécies de Panicoideae (Morrone et al. 1995; Price et al. 2005; Morrone et al. 2006; Sede et al. 2010; Leitch et al. 2010; Bernardo Filho et al. 2014). Além disso, a presença de pelos ferrugíneos nas glumas e antécio inferior são características compartilhadas pelas espécies de Mesosetum com x = 10 (Filgueiras 1986, 1989; Sousa 2014; Silva et al. 2015; Silva dados não publicados).

O citótipo diploide $(2 \mathrm{n}=20)$ encontrado em M. ferrugineum var. setaceum evidencia pela primeira vez a ocorrência de poliploidia dentro da espécie $M$. ferrugineum e também do clado $\mathrm{x}=10$ em Mesosetum. $\mathrm{O}$ número cromossômico $2 \mathrm{n}=60$ já havia sido reportado para M. ferrugineum var. ferrugineum (Sousa 2014), que, portanto, é um hexaploide natural. Entretanto, ainda não foi possível a observação da meiose nesta espécie para comparar como se comporta o pareamento dos cromossomos no diploide $(2 n=20)$ e no hexaploide $(2 n=60)$. A dificuldade de obtenção de inflorescências jovens é o principal entrave ao desenvolvimento de estudos meióticos nesta espécie. O florescimento de $M$. ferrugineum é abrupto e somente 
ocorre após incêndios em seu habitat natural e ainda não houve sucesso na indução do florescimento em suas mudas cultivadas na casa de vegetação.

O segundo clado de Mesosetum possui número cromossômico básico x $=4$ (Ribeiro 2013, Sousa 2014, Ribeiro et al. 2015), o qual não é reportado para nenhum outro gênero de Arthropogoninae. Neste clado, o número cromossômico básico já foi comprovado em 14 espécies, incluindo representantes de Mesosetum sect. Bifaria, M. sect. Loliiformia Swallen e M. sect. Sclerochloae Swallen (Filgueiras 1986, 1989). O clado $\mathrm{x}=4$ possui cromossomos com tamanho de 3,7-7,2 $\mu \mathrm{m}$, os quais chegam a ser até três vezes maiores que os cromossomos das espécies do clado com $\mathrm{x}=10$ (Tabela 3, Figura 2). Não obstante, o clado $\mathrm{x}$ $=4$ apresenta série poliploide até o nível octaploide com registros de $2 \mathrm{n}=8,16,24$ e 32 cromossomos. Quanto à morfologia das espiguetas, o clado $\mathrm{x}=4$ é bastante polimórfico, incluindo espécies com glumas múticas a aristadas, planas a conduplicadas, glabras ou pilosas, com pelos alvos ou vináceos.

A ausência de registros dos números cromossômicos $2 n=8,16,24$ ou 32 em outros gêneros da subtribo Arthropogoninae torna mais plausível a hipótese de que $\mathrm{x}=4$ surgiu dentro do gênero Mesosetum. O cariótipo com x $=4$ provavelmente surgiu por fusão, rearranjos ou perda de cromossomos a partir de espécies com número cromossômico básico $\mathrm{x}$ = 10, que é provavelmente mais basal em Mesosetum (Silva dados não publicados).

A origem de $\mathrm{x}=4$ a partir de $\mathrm{x}=10$ corresponde a maior redução do número cromossômico já registrada na tribo Paspaleae. Uma redução drástica e abrupta do genoma por perda de cromossomos seria deletéria, pois afetaria mais da metade dos genes e codificação de proteínas. Tal fato torna mais provável a hipótese que $\mathrm{x}=4$ surgiu em Mesosetum por fusão ou rearranjos cromossômicos em eventos graduais com possível ocorrência de números cromossômicos intermediários entre $\mathrm{x}=10$ e x $=4$. 
Estudos citológicos em M. agropyroides Mez, podem esclarecer a origem do número cromossômico básico $\mathrm{x}=4$ e devem ser estimulados. $\mathrm{O}$ número cromossômico de $M$. agropyroides ainda é desconhecido e na filogenia de Mesosetum esta espécie forma um ramo mais basal e estritamente relacionado ao clado com $\mathrm{x}=4$ (Silva dados não publicados). As tentativas de coleta de $M$. agropyroides na sua localidade típica e em novas ocorrências foram inexitosas e dificultadas pelo fato do florescimento desta espécie estar relacioanado ao estímulo pelo fogo (Filgueiras 1986, 1989; Silva et al. 2016).

O número cromossômico básico $\mathrm{x}=13$ aqui encontrado em $M$. exaratum ainda não foi observado em nenhuma outra espécie de Mesosetum, o que dificulta discutir sobre sua origem e evolução. O gênero Deschampsia P. Beauv., subfamília Pooideae, possui o maior número de espécies com $2 \mathrm{n}=26$ cromossomos (Tabela 4). Neste gênero, a origem do número cromossômico básico $\mathrm{x}=13$ é atribuída a uma redução a partir do número básico secundário $\mathrm{x}=14$, que por sua vez originou-se por poliploidia a partir de $\mathrm{x}=7$ (Cardone et al. 2009; Amosova et al. 2015).

Em $M$. exaratum a origem de $\mathrm{x}=13$ parece ser distinta. De acordo com a filogenia de Mesosetum baseada em caracteres moleculares (Silva dados não publicados), M. exaratum está mais estritamente relacionada com as espécies do clado $\mathrm{x}=10$. O número cromossômico básico $\mathrm{x}=13$ encontrado em $M$. exaratum provavelmente derivou-se de $\mathrm{x}=10$ por fissão ou duplicação de cromossomos. A presença de dois pares com instabilidade do centrômero em M. exaratum pode ser indício desta tendência de aumento do número cromossômico por fissão centromérica, a qual originou $\mathrm{x}=13$.

Em M. ferrugineum $(2 \mathrm{n}=20)$ também foi encontrado um par com instabilidade centromérica. Este aspecto induz a contagem de 22 cromossomos, porém o exame de algumas células mostra fusos de cromatina ligando os dois fragmentos comprovando que o número cromossômico é realmente $2 \mathrm{n}=20$. A observação de instabilidade centromérica também em 
espécies com $\mathrm{x}=10$ reforça a hipótese de que $\mathrm{x}=13$ surgiu por aumento do número cromossômico desencadeado por fissão centromérica, sugerindo que os números cromossômicos $\mathrm{x}=11 \mathrm{e} \mathrm{x}=12$ também podem ter partcipado da evolução cromossômica de Mesosetum.

\subsection{Conclusão}

As espécies do clado $\mathrm{x}=10$ são provavelmente as mais basais de Mesosetum e compartilham o mesmo número cromossômico dos gêneros irmãos pertencentes a subtribo Arthropogoninae. Dentro de Mesosetum a evolução por meio de mudanças em ordem cromossômica orginou pelo menos três linhagens correspondentes aos números básicos $\mathrm{x}=4$, $\mathrm{x}=10$ e $\mathrm{x}=13$

$\mathrm{O}$ clado $\mathrm{x}=10$ provavelmente manteve o conjunto cromossômico mais conservado e semelhante ao ancestral. $\mathrm{O}$ clado $\mathrm{x}=4$ e a linhagem $\operatorname{com} \mathrm{x}=13$, derivados a partir de $\mathrm{x}=10$, seguiram rotas de evolução cromossômica divergentes, a primeira $(x=4)$ por redução e a segunda $(\mathrm{x}=13)$ por aumento.

A ampliação dos estudos envolvendo contagens cromossômicas e caracterização citogenética avançada deve ser estimulada para elucidar a origem dos números cromossômicos raros, $\mathrm{x}=4 \mathrm{e} \mathrm{x}=13$, encontrados em Mesosetum. A caracterização citogenética de outros gêneros e espécies de Arthropogoninae e Paspaleae também deve ser conduzida, tendo em vista que auxiliará e complementará o conhecimento acerca da evolução cromossômica em Mesosetum.

\subsection{Referências}

Albers F (1980) Comparative karyology of the grass subtribes Aristaveninae and Airinae (Poaceae-Avenae). Plant Systematics and Evolution 136: 137-167 
Amosova AV, Bolsheva NL, Samatadze TE, Twardovska MO, Zoshchuk SA, Andreev IO, Badaeva ED, Kunakh VA, Muravenko OV (2015) Molecular Cytogenetic Analysis of Deschampsia antarctica Desv. (Poaceae), Maritime Antarctic. PLoS ONE 10(9): 1-17

Arohonka T (1982) Chromosome counts of vascular plants of the island Seili in Nauvo, southwestern Finland. Turun Yliopiston Julkaisuja, Sar. A 2 Biology Geography 3: 1-12 Belaeva VA, Siplivinsky V (1981) Chromosome number reports LXXIII. Taxon 30: 857-860 Bernardo Filho RA, Santos AC, Souza FH, Valls JFM, Pagliarini MS (2014) Complete asynapsis resulting in 2n pollen formation in Paspalum jesuiticum Parodi (Poaceae). Genetics and Molecular Research 13(1): 255-261

Beuzenberg EJ, Hair JB (1983) Contributions to a chromosome atlas of the New Zealand flora - 25 miscellaneous species. New Zealand Journal of Botany. 21: 13-20

Burke SV, Wysocki WP, Zuloaga FO, Craine JM, Pires JC, Edger PP, Mayfield-Jones D, Clark LG, Kelchner SA, Duvall MR (2016) Evolutionary relationships in Panicoid grasses based on plastome phylogenomics (Panicoideae; Poaceae). BMC Plant Biology 16(140): 1-11

Cardone S, Sawatani P, Rush P, García AM, Poggio L, Schrauf G (2009) Karyological studies in Deschampsia antarctica Desv. (Poaceae). Polar Biology 32: 427-433

Celarier R, Paliwal R (1957) Basic chromosome number of four in the subfamily Panicoideae of the Gramineae. Science 126: 1247

Cuccuini P, Fiorini G (2004) Genere Hainardia Grueter (Poaceae) in Italia. Note tassonomiche, citologiche ed ecologiche. . Webbia 59(1): 149-175

Dalgaard V (1991) Chromosome studies in flowering plants from Macaronesia II. Willdenowia 20: 139-152 
Davidse G, Pohl RW (1972) Chromosome numbers, meiotic behavior, and notes on some grasses from Central America and the West Indies. Canadian Journal of Botany 50: $1441-1452$

De Wet JMJ (1987) Hybridization and polyploidy in the Poaceae. In: Soderstrom TR, Hilu KW, Campbell CS, Barkworth MA (eds.) Grass systematics and evolution, Smithsonian Inst. Press., Washington DC, pp 188-194

Devesa JA, Zarco CR (1984) Números cromosómicos para la flora española Lagascalia 12: 290-292

Devesa JA, Ruiz T, Tormo R, Muñoz A, Viera MC, Carrasco J, Ortega A, Pastor J (1990) Contribución al conocimiento cariológico de las Poaceae en Extremadura II. Boletim da Sociedade Broteriana 63: 153-205

Devesa JA, Ruiz T, Viera MC, Tormo R, F. Vázquez, Carrasco JP, Ortega A, Pastor J (1991) Contribución al conocimiento cariológico de las Poaceae en Extremadura (España)III., sér. 2 Boletim da Sociedade Broteriana 64: 35-74

Druskovic B, Lovka M (1995) IOPB chromosome data 9 International Organization of Plant Biosystematists 24: 15-19

Filgueiras TS (1986) O gênero Mesosetum Steudel (Gramineae: Paniceae). Tese de Doutorado, Universidade Estadual de Campinas, Campinas-SP, Brazil

Filgueiras TS (1989) Revisão de Mesosetum Steudel (Gramineae: Paniceae). Acta Amazônica 19: $47-114$

Filgueiras TS, Silva AS, Oliveira RC (2016) Mesosetum In Lista de Espécies da Flora do Brasil. Jardim Botânico do Rio de Janeiro, Brazil. Available at: http://floradobrasil.jbrj.gov.br/jabot/floradobrasil/FB13355, Accessed 18 Jan. 2016

Garciá-Suárez R, Alonso-Blanco C, Fernández-Carvajal MC, Fernández Prieto JA, Roca A, Giraldez R (1997) Diversity and systematics of Deschampsia sensu lato (Poaceae) 
inferred from karyotypes, protein electrophoresis, total genomic DNA hybridization and chloroplast DNA analysis. Plant Systematics and Evolution 205: 99-110

Goldblatt P, Johnson DE (2016) Index to plant chromosome numbers 1979-onwards. Missouri Botanical Garden, St. Louis, USA. Available at: http://www.tropicos.org/Project/IPCN, Accessed 23 Nov. 2016

Gould FW (1966) Chromosome numbers of some Mexican grasses. Canadian Journal of Botany 44: 1683-1696

Gould FW, Soderstrom TR (1967) Chromosome numbers of tropical American grasses. American Journal of Botany 54: 676-683

Group GGPW (2001) Phylogeny and subfamilial classification of the grasses (Poaceae). Annals of the Missouri Botanical Garden 88(3): 373-457

Guerra M, Souza MJ (2002) Como observar cromossomos: um guia de técnicas em citgenética vegetal, animal e humana. Fundação de Pesquisas Científicas de Ribeirão Preto, Ribeirão Preto, SP

Hidalgo MIM, Caponio I, Norman GA (2007) Citogenética y biología reproductiva de Anthaenantia lanata (Kunth) Benth. (Poaceae: Panicoideae). Kurtziana 33(2): 27-33

Hilu K (2004) Phylogenetics and chromosomal evolution in the Poaceae (grasses). Australian Journal of Botany 52: 13-22

Kerguelen M (1975) Les Gramineae (Poaceae) de la flore Francaise essai de mise au point taxonomique et nomenclaturale. Lejeunia 75: 1-343

Kessler JW, Hatch SL (1984) Chromosome Number Reports LXXXII. Taxon 33: 126-134

Ko|3zuharov SI, Petrova AV (1991) Chromosome numbers of Bulgarian angiosperms. Fitologija 39: 72-77

Krahulcová A (2003) Chromosome numbers in selected monocotyledons (Czech Republic, Hungary, and Slovakia) Preslia 75: 97-113 
Leitch IJ, Beaulieu JM, Chase MW, Leitch AR, Fay MF (2010) Genome Size Dynamics and Evolution inMonocots. Journal of Botany ID 862516: 1-18

Měsíček J (1992) List of Chromosome Numbers of the Czech Vascular Plants. Academia, Praha:

Morrone O, Hunziker JH, Zuloaga FO, Escobar A (1995) Números cromosómicos en Paniceae sudamericanas (Poaceae: Panicoideae). Darwiniana 3(1-4): 53-60

Morrone O, Escobar A, Zuloaga FO (2006) Chromosome studies in American Panicoideae (Poaceae). Annals of the Missouri Botanical Garden 93: 647-657

Morrone O, Aagesen L, Scataglini MA, Salariato DL, Denham SS, Chemisquy MA, Sede SM, Giussani LM, Kellogg EA, Zuloaga FO (2012) Phylogeny of the Paniceae (Poaceae: Panicoideae): integrating plastid DNA sequences and morphology into a new classification. Cladistics 28: 333-356

Murat F, Xu J-H, Tannier E, Abrouk M, Guilhot N, Pont C, Messing J, Salse J (2010) Ancestral grass karyotype reconstruction unravels new mechanisms of genome shuffling as a source of plant evolution. Genome Research 20: 1545-1557

Murray BG, Lange PJ, Ferguson AR (2005) Nuclear DNA variation, chromosome numbers and polyploidy in the endemic and indigenous grass flora of New Zealand. Annals of Botany 96: 1293-1305

Pashuk HT (1980) Comparative cytogenetic investigation of Deschampsia caespitosa and Anthoxanthum alpinum in the primary and secondary communities. Citol. Genet. 14(4): $47-53$

Paterson AH, Bowers JE, Chapman BA (2004) Ancient polyploidization predating divergence of the cereals, and its consequences for comparative genomics. Proceedings of the National Academy of Sciences of the United States of America 101(26): 9903-9908 
Petrovsky VV, Zhukova PG (1981) Chromosome numbers and taxonomy of some plant species of Wrangel Island. Botanicheskii Zhurnal 66(3): 380-387

Pohl RW, Davidse G (1971) Chromosome numbers of Costa Rican grasses. Brittonia 23: 293324

Pozzobon MT, Valls JFM (1997) Chromosome number in germplasm accessions of Paspalum notatum (Gramineae). Brazilian Journal of Genetics 20: 29-34

Pozzobon MT, Paganella MB, Santos S, Valls JFM (2013) Cytological and reproductive aspects in the Caespitosa group of Paspalum. Ciência Rural 43 (11): 2004-2010

Price HJ, Dillon SL, Hodnett G, Rooney WL, Ross L, Johnston JS (2005) Genome Evolution in the Genus Sorghum (Poaceae). Annals of Botany 95: 219-227

Probatova NS (2004) Chromosome numbers of selected vascular plant species from Sakhalin, Moneron and the Kurile Islands. Biodiversity and biogeography of the Kuril Islands Sakhalin 1: 15-23

Probatova NS (2005) A progress in the study of the chromosome numbers of rare and endemic species of the flora of the Russian Far East. Karyology, Karyosystematics and Molecular Phylogeny: 85-86

Probatova NS (1984) New taxa of the Poaceae from the Far East of the USSR. Botanicheskii Zhurnal 69(2): 251-259

Probatova NS, Seledets VP, Barkalov VY (2015) Chromosome numbers in some species of Poaceae from Russia. Botanica Pacifica 4(1):

Rao Y (1975) Evolutionary trends in the Indian Iseilema. Nature 255: 220-221

Reeder JR (1982) Systematics of the tribe Orcuttieae (Gramineae) and the description of a new segregate genus, Tuctoria. . American Journal of Botany 69(7): 1082-1095 
Ribeiro ARO (2013) Citogenética, reprodução e variabilidade morfológica de espécies de Mesosetum sect. Bifaria (Hack.) Chase (Poaceae: Paniceae). Dissertação de Mestrado, Universidade de Brasília, Brasília-DF, Brazil

Ribeiro ARO, Sousa MWS, Oliveira RC, Araujo ACG, Fagg CW, Pozzobon MT (2015) Cytological studies in four species of Mesosetum (Arthropogoninae) reveal the lowest chromosome number among the Neotropical Poaceae. Plant Systematics and Evolution 301(10): 2377-2386

Sede S, Escobar A, Morrone O, Zuloaga FO (2010) Chromosome studies in American Paniceae (Poaceae-Panicoideae). Annals of the Missouri Botanical Garden 97: 128-138

Silva AS, Ribeiro ARO, Sousa MWS, Fagg CW, Falcão R, Oliveira RC (2015) Micromorphology of the upper anthecium in Mesosetum Steud. and related genera (Poaceae, Arthropogoninae) and its taxonomic applications. Rodriguésia 66(2): 645-657

Silva AS (dados não publicados) Filogenia de Mesosetum Steud. (Paspaleae: Poaceae) com base caracteres moleculares. Tese de Doutorado, Universidade de Brasília, Brasília-DF, Brazil

Silva LAC, Pagliarini MS, Santos SA, Silva N, Souza VF (2012) Chromosome number, microsporogenesis, microgametogenesis, and pollen viability in the Brazilian native grass Mesosetum chaseae (Poaceae). Genetics and Molecular Research 11(4): 41004109

Soreng RJ, Peterson PM, Romaschenko K, Davidse G, Zuloaga FO, Judziewicz EJ, Filgueiras TS, Davis JI, Morrone O (2015) A worldwide phylogenetic classification of the Poaceae (Gramineae). Journal of Systematics and Evolution 53(2): 117-137

Sousa MWS (2014) Citogenética e morfologia de espécies de Mesosetum Steud. (Poaceae, Paspaleae). Dissertação de Mestrado, Universidade de Brasília, Brasília-DF, Brazil 
Souza LGR, Crosa O, Winge H, Guerra M (2009) The karyotype of Nothoscordum arenarium Herter (Gilliesioideae, Alliaceae): A populational and cytomolecular analysis. Genetics and Molecular Biology 32(1): 111-116

Souza LGR, Crosa O, Speranza P, Guerra M (2012) Cytogenetic and molecular evidence suggest multiple origins and geographical parthenogenesis in Nothoscordum gracile (Alliaceae). Annals of Botany 109: 987-999

Stoeva MP (1982) IOPB chromosome number reports LXXVI. Taxon 31: 579-580

Strid A, Franzen R (1983) Chromosome numbers in flowering plants from Greece. Willdenowia 13: 329-333

Studer AJ, Schnable JC, Weissmann S, Kolbe AR, McKain MR, Shao Y, Cousins AB, Kellogg EA, Brutnell TP (2016) The draft genome of the C3 panicoid grass species Dichanthelium oligosanthes. Genome Biology 17(223): 1-18

Swallen JR (1937) The grass genus Mesosetum. Brittonia 2(4): 363-392

Thiers B (2016) Index Herbariorum: A global directory of public herbaria and associated staff. New York Botanical Garden's Virtual Herbarium. Available at: http://sweetgum.nybg.org/ih/, Accessed 02 Feb. 2016

USDA, ARS [National Genetic Resources Program] (2016) Germplasm Resources Information Network - GRIN (Online Database). National Germplasm Resources Laboratory, Beltsville, Maryland. Available at: https://npgsweb.arsgrin.gov/gringlobal/taxonomylist.aspx $?$ category $=$ genera\&type $=$ family $\&$ value $=$ Poaceae \&id=897, Accessed 03 Nov. 2016

Wang X, Wang J, Jin D, Guo H, Lee T-H, Liu T, Paterson AH (2015) Genome Alignment Spanning Major Poaceae Lineages Reveals Heterogeneous Evolutionary Rates and Alters Inferred Dates for Key Evolutionary Events. Molecular Plant 8: 885-898 
Zhao Y, Tang L, Li Z, Jin J, Luo J, Gao G (2015) Identification and analysis of unitary loss of longestablished protein-coding genes in Poaceae shows evidences for biased gene loss and putatively functional transcription of relics. BMC Evolutionary Biology 15(66): 210

Zhukova PG, Petrovsky VV (1980) Chromosome numbers and taxonomy of some species of the Anyui Mts. Botanicheskii Zhurnal 65(5): 651-659

Zhukova PG (1980) Chromosome numbers of some Southern Chukotka plant species. Botanicheskii Zhurnal 65 (1): 51-59

Zhukova PG (1982) Chromosome numbers of some plant species of north-eastern Asia. Botanicheskii Zhurnal 67(3): 360-365 


\section{CAPÍTULO 2}

Estudos de citometria de fluxo e tamanho do genoma em espécies de Mesosetum Steud.

(Poaceae: Paspaleae) e outros gêneros de Arthropogoninae 


\subsection{Introdução}

A variação do número cromossômico aliada aos processos de poliploidia, hibridação e diploidização foram determinantes na evolução do genoma das espécies de Poaceae (De Wet 1987; Hilu 2004; Shapova et al. 2012; Wang et al. 2015; Studer et al. 2016). Entre estes processos, a autopoliploidia e a alopoliploidia foram os eventos que mais contribuíram ao aumento do tamanho do genoma em todas as principais linhagens de Poaceae (Hunziker \& Stebbins 1987; Schnable et al. 2012).

Enquanto mudanças estruturais dos nucleotídeos propiciaram a neofuncionalização ou subfuncionalização de genes, a multiplicação de todo complemento cromossômico básico forneceu cópias extras de genes essenciais à sobrevivência, possibilitando oportunidades de inovação genética (Hunziker \& Stebbins 1987; Wang et al. 2015; Studer et al. 2016).

O aumento do genoma desencadeado pela poliploidia foi seguido por uma recíproca perda de cópias redundantes de genes principalmente por fracionação durante a irradiação de novas espécies (Langham et al. 2004; Paterson et al. 2004; Schnable et al. 2012). Embora ainda seja pouco compreendido, este processo de perda de genes que ocorreu paralelo à diploidização constitui-se na causa mais importante dos subsequentes eventos de redução do genoma nas espécies de Poaceae (Murat et al. 2010, Schnable et al. 2012).

Na subfamília Panicoideae, o incremento por poliploidização seguido por redução mediante perdas de seqüências de DNA também se processou repetidas vezes no genoma de suas espécies (Langham et al. 2004; Price et al. 2005; Leitch et al. 2010; Schnable et al. 2012; Wang et al. 2015). Estes eventos de expansão e regressão do tamanho do genoma estão estritamente relacionados com a evolução cromossômica de Panicoideae, a qual apresenta predomínio dos números cromossômicos básicos $\mathrm{x}=5, \mathrm{x}=9$ e $\mathrm{x}=10$ em suas espécies (Hilu 2004; Price et al. 2005; Morrone et al. 2006; Sede et al. 2010; Murat et al. 2010; Pozzobon et al. 2013; Burke et al. 2016). 
O cariótipo ancestral de Panicoideae provavelmente possuía número cromossômico básico $\mathrm{x}=11$, observado no monotípico basal Gynerium sagittatum (Aubl.) P. Beauv. O número cromossômico básico $\mathrm{x}=11$ foi perdido na maioria dos gêneros de Panicoideae, os quais possuem predomínio do número cromossômico básico $\mathrm{x}=10$ em suas espécies mais basais (Hilu 2004; Price et al. 2005; Murat et al. 2010, Burke et al. 2016). O cariótipo de vários gêneros de Panicoideae, além do número cromossômico básico $\mathrm{x}=10$, possui tamanho cromossômico e genomas pequenos com valor modal de quantidade de DNA por cromossomo (2C/2n) igual a 0,1 pg (Leitch et al. 2010). Estas cacterísticas foram conservadas em algumas espécies ou se derivaram originando cromossomos e genomas maiores, tanto múltiplos de $\mathrm{x}=$ 10, como de outros números básicos (Price et al. 2005; Leitch et al. 2010; Vaio et al. 2007; Galdeano et al. 2016).

Além dos números cromossômicos básicos mais comuns $\mathrm{x}=5, \mathrm{x}=9$ e $\mathrm{x}=10$, as espécies de Panicoideae possuem registros de números cromossômicos pouco usuais como $\mathrm{x}$ $=4$ (Celarier \& Paliwal 1957; Ribeiro 2013; Sousa 2014; Ribeiro et al. 2015). A origem de x = 4 em Panicoideae ainda é pouco compreendida, sendo registrada somente nos gêneros Iseilema Andersson (Tribo Andropogoneae) e Mesosetum Steud. (Tribo Paspaleae). Entre as gramíneas neotropicais, Mesosetum é o único gênero com registro do número cromossômico $2 \mathrm{n}=8(\mathrm{x}=4)$, o qual também é o menor número cromossômico já registrado entre as Poaceae dos neotrópicos.

O gênero Mesosetum foi posicionado na tribo Paspaleae, subtribo Arthropogoninae na última filogenia da tribo Paniceae s.l. (Morrone et al. 2012). A tribo Paspaleae engloba espécies americanas que compõe um clado com número cromossômico básico $\mathrm{x}=10$. A subtribo Arthropogoninae é composta por gêneros heterogêneos do ponto de vista morfológico, no qual Mesosetum destaca-se por ter o maior número de espécies. Dentro de 
Arthropogoninae, Mesosetum compõe um clado altamente suportado com os gêneros Keratochlaena Morrone e Tatianyx Zuloaga \& Soderstr. (Morrone et al. 2012).

O gênero Mesosetum possui 25 espécies e tem distribuição geográfica neotropical desde o sul do México até o nordeste da Argentina (Swallen 1937; Filgueiras 1986, 1989; Filgueiras et al. 2016). O Brasil é o centro de diversidade do gênero com ocorrência de 22 espécies, 16 das quais no bioma cerrado (Filgueiras et al. 2016; Silva et al. 2016).

Estudos moleculares em andamento (Silva dados não publicados), incluindo 24 espécies de Mesosetum mostraram que o gênero pode ser subdividido em pelo menos três linhagens correspondentes aos números cromossômicos básicos $\mathrm{x}=10, \mathrm{x}=13$ e $\mathrm{x}=4$ (Capítulo 1 desta tese). $\mathrm{O}$ clado com número cromossômico básico $\mathrm{x}=10$ é provavelmente $\mathrm{o}$ mais basal e conecta Mesosetum com os gêneros irmãos em Arthropogoninae. O clado x = 4 provalvelmente derivou-se de $\mathrm{x}=10$ por redução do número cromossômico, enquanto a linhagem monoespecífica de M. exaratum (Trin.) Chase com x $=13$ derivou-se por aumento.

A variação dos números cromossômicos em série múltipla com $2 n=20$ e $2 n=60$ para o clado $x=10$, bem como $2 n=8,2 n=16,2 n=24$ e $2 n=32$ para o clado $x=4$ comprova a ocorrência de poliploidia durante a evolução das espécies de Mesosetum (Capítulo 1 desta tese de doutorado; Ribeiro 2013; Sousa 2014; Ribeiro et al. 2015). A poliploidia em Mesosetum também é comprovada pela ocorrência de associações múltiplas em trivalentes e quadrivalentes na meiose das espécies com $2 n=16$ e 2n $=24$ cromossomos (Ribeiro 2013).

Além da poliploidia, os rearranjos cromossômicos provavelmente também ocorreram durante a evolução das espécies de Mesosetum. Eventos de fusão, translocação ou perda de cromossomos estão implícitos na origem do clado $\operatorname{com} \mathrm{x}=4$ a partir de $\mathrm{x}=10$. Já a origem de $\mathrm{x}=13$ a partir de $\mathrm{x}=10$ provavelmente pode estar associada a eventos de fissão ou duplicações de cromossomos (Capítulo 1 desta tese de doutorado). 
Entretanto, estudos acerca do tamanho do genoma e quantidade de DNA são escassos em Panicoideae e inexistentes na subtribo Arthropogoninae, o que impossibilita avaliar como os eventos de poliploidia ou redução do número cromossômico interferiram na evolução do genoma de suas espécies.

O objetivo do presente capítulo foi estimar o tamanho do genoma de espécies de Arthropogoninae, com enfoque especial no gênero Mesosetum por meio de ensaios de citometria de fluxo, visando fornecer parâmetros acerca da evolução de suas espécies.

\subsection{Material e Métodos}

Foram realizadas expedições para diferentes regiões do Brasil com o objetivo de obter as plantas vivas para estudo. As expedições foram planejadas com base nos dados da revisão de herbários nacionais e internacionais B, BAA, BM, CAY, CEN, CPAP, ESA, F, G, HB, HEPH, HRB, HUEFS, HUTO, IAN, IBGE, ICN, IPA, K, LE, MG, MHS, MO, MOSS, NX, P, PAMG, R, RB, S, SP, SP, UB, UEC, UFMT, UFRN, US e VEN (acrônimos disponíveis em Thiers 2016), além da base de dados do SpeciesLink (2016) para determinação tanto dos locais quanto das épocas de florescimento das espécies.

Foram realizadas coletas no Distrito Federal e estados do Amazonas, Bahia, Goiás, Mato Grosso, Minas Gerais, Pernambuco e Tocantins, entre janeiro de 2013 a fevereiro de 2016. As mudas foram obtidas de touceiras, cultivadas na casa de vegetação da Universidade de Brasília e os vouchers depositados no herbário UB.

As plantas de 19 acessos, incluindo uma espécie de Arthropogon Nees, 13 espécies de Mesosetum e uma espécie de Tatianyx (Tabela 1) foram propagadas vegetativamente por meio de estolhos e fragmentação da touceira. Os propágulos foram implantados e cultivados ainda na casa de vegetação do Laboratório de Citogenética Vegetal, Universidade Federal de Pernambuco - UFPE, junto com as mudas das espécies padrão. 
Tabela 1. Discriminação da espécies de Mesosetum e outros gêneros de Arthropogoninae com respectivos acessos e locais de coleta utilizados nas análises de citometria de fluxo

\begin{tabular}{|c|c|c|c|}
\hline Espécie analisada & Acesso & Local de Coleta & Espécie padrão \\
\hline $\begin{array}{l}\text { Arthropogon villosus } \\
\text { Nees }\end{array}$ & RCO 2971 & $\begin{array}{l}\text { Brasil, Distrito Federal, } \\
\text { Brasília }\end{array}$ & Soja \\
\hline Mesosetum alatum Filg. & RCO 2765 & Brasil, Mato Grosso, Água Boa & Tomate \\
\hline $\begin{array}{l}\text { Mesosetum ansatum } \\
\text { (Trin.) Kuhlm. }\end{array}$ & RCO 2766 & Brasil, Mato Grosso, Poconé & Rabanete \\
\hline $\begin{array}{l}\text { Mesosetum ansatum } \\
\text { (Trin.) Kuhlm. }\end{array}$ & RCO 2784 & $\begin{array}{l}\text { Brasil, Mato Grosso, Chapada } \\
\text { dos Guimarães }\end{array}$ & Rabanete \\
\hline $\begin{array}{l}\text { Mesosetum bifarium } \\
\text { (Hack.) Chase }\end{array}$ & V 15927 & Brasil, Goiás, Flores de Goiás & Tomate \\
\hline $\begin{array}{l}\text { Mesosetum bifarium } \\
\text { (Hack.) Chase }\end{array}$ & V 15933 & Brasil, Goiás, Flores de Goiás & Tomate \\
\hline $\begin{array}{l}\text { Mesosetum bifarium } \\
\text { (Hack.) Chase }\end{array}$ & ASS 235 & $\begin{array}{l}\text { Brasil, Goiás, Teresina de } \\
\text { Goiás }\end{array}$ & Tomate \\
\hline $\begin{array}{l}\text { Mesosetum cayennense } \\
\text { Steud. }\end{array}$ & RCO 2848 & Brasil, Tocantins, Natividade & Milho \\
\hline $\begin{array}{l}\text { Mesosetum cayennense } \\
\text { Steud. }\end{array}$ & AROR 362 & Brasil, Goiás, Pirenópolis & Rabanete \\
\hline $\begin{array}{l}\text { Mesosetum chaseae } \\
\text { Luces }\end{array}$ & RCO 2772 & Brasil, Mato Grosso, Poconé & Tomate \\
\hline $\begin{array}{l}\text { Mesosetum compressum } \\
\text { Swallen }\end{array}$ & ASS 274 & Brasil, Pernambuco, Pesqueira & Tomate \\
\hline $\begin{array}{l}\text { Mesosetum elytrochaetum } \\
\text { (Hack.) Swallen }\end{array}$ & AROR 377 & Brasil, Goiás, Alto Paraíso & Milho \\
\hline $\begin{array}{l}\text { Mesosetum exaratum } \\
\text { (Trin.) Chase }\end{array}$ & AROR 351 & $\begin{array}{l}\text { Brasil, Minas Gerais, Serra do } \\
\text { Cipó }\end{array}$ & Tomate \\
\hline $\begin{array}{l}\text { Mesosetum ferrugineum } \\
\text { var. setaceum Filg. }\end{array}$ & AROR 409 & Brasil, Bahia, Rio de Contas & Rabanete \\
\hline $\begin{array}{l}\text { Mesosetum ferrugineum } \\
\text { var.ferrugineum (Trin.) } \\
\text { Chase }\end{array}$ & MWSS 64 & $\begin{array}{l}\text { Brasil, Distrito Federal, } \\
\text { Brasília }\end{array}$ & Tomate \\
\hline $\begin{array}{l}\text { Mesosetum loliiforme } \\
\text { (Hochst. ex Steud.) Chase }\end{array}$ & AROR 355 & Brasil, Goiás, Pirenópolis & Tomate \\
\hline $\begin{array}{l}\text { Mesosetum } \\
\text { rottboellioides (Kunth) } \\
\text { Hitchc. }\end{array}$ & PAR 331 & $\begin{array}{l}\text { Brasil. Minas Gerais, Grão } \\
\text { Mogol }\end{array}$ & Rabanete \\
\hline $\begin{array}{l}\text { Mesosetum } \\
\text { rottboellioides (Kunth) } \\
\text { Hitchc. }\end{array}$ & AROR 420 & Brasil, Bahia, Rio de Contas & Milho \\
\hline
\end{tabular}


As espécies padrão são aquelas que possuem quantidade de DNA já conhecida e foram escolhidas com base na lista padrão de Dolezel et al. (1992, 1998, 2005). Para cada espécie examinada foi escolhida uma espécie padrão (Tabela 1) com tamanho do genoma distinto o suficiente para evitar sobreposição entre os picos (Dolezel 1992, 1998, 2005). Com base nesses critérios, as espécies padrão selecionadas foram o rabanete (Raphanus sativus L. cultivar "Saxa", 2C = 1,11 pg), tomate (Solanum lycopersicum L. cultivar "Stupicke Polni Tyckove Rane", 2C =1,96 pg), a soja (Glycine $\max (\mathrm{L}$.) Merr. cultivar "Polanka", 2C = 2,50 pg) e o milho (Zea mays L. cultivar “CE-777”, 2C=5,43 pg).

Para o preparo das amostras, 40-50 mg de tecido de folhas jovens frescas das espécies analisadas e das espécies padrão foram simultaneamente picadas para liberação dos núcleos celulares em placa petri com $750 \mu \mathrm{L}$ de solução tampão WPB (Wood Plant Buffer) descrita por Loureiro et al. (2007). A suspensão contendo os núcleos foi filtrada em malha de $30 \mu \mathrm{m}$ de poro e o conteúdo depositado em tubo de citômetro. A seguir foram adicionados mais 750 de solução tampão WPB, $20 \mu \mathrm{L}$ de solução de iodeto propídio $(50 \mu \mathrm{g} / \mathrm{mL})$ e o tubo foi agitado para homogeneizar o corante. Posteriormente, as amostras foram armazenadas em caixa com gelo até análise.

Como foi utilizado tecido somático (2n) de folhas, a quantidade de DNA estimada em cada núcleo representa o tamanho do genoma diplofásico (2C). Para estimar a quantidade de DNA do genoma de cada planta, as amostras foram analisadas em citômetro de fluxo Partec CyFlow SL sob feixe laser verde de $532 \mathrm{~nm}$ equipado com o programa Flomax (Partec), no Laboratório de Citogenética e Evolução Vegetal, UFPE. O valor da quantidade de DNA de cada acesso foi determinado pela média de três repetições com pelo menos 1000 núcleos 
avaliados em cada repetição. Foram utilizados somente histogramas com picos contendo Coeficiente de Variação menor ou igual 5\%.

Para facilitar a comparação dos tamanhos dos genomas entre os distintos números cromossômicos básicos e níveis de ploidia foram calculadas a quantidade de DNA do genoma monoploide $(\mathrm{Cx})$ e a quantidade média de DNA por cromossomo $(2 \mathrm{C} / 2 \mathrm{n})$ de acordo com as fórmulas descritas por Greilhuber et al. (2005) e Leitch. et al. (2010). O valor de Cx é obtido pela divisão da quantidade de DNA do genoma diplofásico (2C) pelo número de complementos monoploides $(\mathrm{x})$ do respectivo nível de ploidia (Greilhuber et al. 2005). O valor da quantidade média de DNA por cromossomo $(2 \mathrm{C} / 2 \mathrm{n})$ é obtido pela divisão da quantidade de DNA do genoma diplofásico (2C) pelo número cromossômico somático (2n) (Leitch. et al. 2010).

\subsection{Resultados}

Foi estimada a quantidade de DNA (2C) por citometria de fluxo em 19 acessos incluindo uma espécie de Arthropogon, 13 espécies de Mesosetum e uma espécie de Tatianyx (Tabela 2, Figuras 1 e 2). Foram observados três grupos com quantidade de DNA distintas, sendo o primeiro representado pelas espécies com número básico $\mathrm{x}=10$, o segundo representado pela espécie com $x=13$ e o terceiro representado pelas espécies com $x=4$.

O clado de espécies com número básico $\mathrm{x}=10$ apresentou nos diploides $(2 \mathrm{n}=20) M$. cayennense, M. ferrugineum var. setaceum e M. rottboellioides a menor quantidade de DNA entre todas as espécies estudadas, variando entre $2 \mathrm{C}=0,8850 \mathrm{pg}$ e $2 \mathrm{C}=1,9456 \mathrm{pg}$ (Tabela 2). O tetraploide $(2 \mathrm{n}=40)$ Arthropogon villosus apresentou quantidade de DNA 2C $=5,3375 \mathrm{pg}$. Os hexaploides $(2 \mathrm{n}=60)$ M. ferrugineum var. ferrugineum e Tatianyx arnacites apresentaram quantidades de DNA de $2 \mathrm{C}=4,6079 \mathrm{pg}$ e $2 \mathrm{C}=3,5951 \mathrm{pg}$, respectivamente. 
A linhagem monoespecífica de $M$. exaratum com $2 \mathrm{n}=26(\mathrm{x}=13)$ apresentou quantidade de DNA de $2 \mathrm{C}=3,3238$ pg (Tabela 2). Já o clado de espécies com número cromossômico básico $\mathrm{x}=4$ apresentou quantidade de DNA nos diploides $(2 \mathrm{n}=8)$ das espécies Mesosetum alatum, $M$. ansatum e $M$. bifarium variando entre 2C $=2,1264$ pg e 2C = 3,6284 pg (Tabela 2). Para os tetraploides $(2 \mathrm{n}=16)$ de $M$. bifarium (ASS 235) e $M$. compressum (ASS 274) obteve-se $2 \mathrm{C}=4,8023$ pg e $2 \mathrm{C}=5,1935 \mathrm{pg}$, respectivamente. Nos hexaploides $(2 \mathrm{n}=24)$ de $M$. chaseae e $M$. elytrochaetum foram observadas as maiores quantidades de DNA entre todas as espécies examinadas com 2C $=5,7903$ e 2C $=9,0172$ pg em M. elytrochaetum.

Tabela 2. Quantidade de DNA do genoma diplofásico (2C) das espécies de Arthropogon, Mesosetum e Tatianyx estimadas por citometria de fluxo, seus respectivos números cromossômicos, nível de ploidia, quantidade de DNA do genoma monoploide $(\mathrm{Cx})$ e quantidade média de DNA por cromossomo $(2 \mathrm{C} / 2 \mathrm{n})$

\begin{tabular}{|c|c|c|c|c|c|c|c|}
\hline & Espécie analisada & Acesso & $\begin{array}{l}\text { Num. } \\
\text { crom. }\end{array}$ & $\begin{array}{l}\text { Nível } \\
\text { Ploid. }\end{array}$ & $\begin{array}{c}2 \mathrm{C} \\
(\mathrm{pg})\end{array}$ & $\begin{array}{l}\mathrm{Cx} \\
(\mathbf{p g})\end{array}$ & $\begin{array}{c}2 \mathrm{C} / 2 \mathrm{n} \\
(\mathrm{pg})\end{array}$ \\
\hline \multirow{8}{*}{$\underset{\pi}{\otimes}$} & Arthropogon villosus Nees & RCO 2971 & $2 n=40$ & $4 \mathrm{x}$ & 5,3375 & 1,3344 & 0,1334 \\
\hline & $\begin{array}{l}\text { Mesosetum cayennense } \\
\text { Steud. }\end{array}$ & RCO 2848 & $2 n=20$ & $2 \mathrm{x}$ & 0,8850 & 0,4425 & 0,0443 \\
\hline & $\begin{array}{l}\text { Mesosetum cayennense } \\
\text { Steud. }\end{array}$ & AROR 362 & $2 n=20$ & $2 \mathrm{x}$ & 1,5171 & 0,7586 & 0,0759 \\
\hline & $\begin{array}{l}\text { Mesosetum ferrugineum } \\
\text { var. setaceum Filg. }\end{array}$ & AROR 409 & $2 n=20$ & $2 \mathrm{x}$ & 1,9456 & 0,9728 & 0,0973 \\
\hline & $\begin{array}{l}\text { Mesosetum ferrugineum } \\
\text { var. ferrugineum (Trin.) } \\
\text { Chase }\end{array}$ & MWSS 64 & $2 n=60$ & $6 x$ & 4,6079 & 0,7680 & 0,0768 \\
\hline & $\begin{array}{l}\text { Mesosetum rottboellioides } \\
\text { (Kunth) Hitchc. }\end{array}$ & PAR 331 & $2 n=20$ & $2 \mathrm{x}$ & 1,2895 & 0,6448 & 0,0645 \\
\hline & $\begin{array}{l}\text { Mesosetum rottboellioides } \\
\text { (Kunth) Hitchc. }\end{array}$ & AROR 420 & indet. & - & 1,8949 & - & - \\
\hline & $\begin{array}{l}\text { Tatianyx arnacites (Trin.) } \\
\text { Zuloaga \& Soderstr. }\end{array}$ & AROR 411 & $2 n=60$ & $6 \mathrm{x}$ & 3,5951 & 0,5992 & 0,0599 \\
\hline$\prod_{\pi}^{m}$ & $\begin{array}{l}\text { Mesosetum exaratum } \\
\text { (Trin.) Chase }\end{array}$ & AROR 351 & $2 n=26$ & $2 \mathrm{x}$ & 3,3238 & 1,6619 & 0,1278 \\
\hline \multirow{2}{*}{$\prod_{\star}^{\mathbb{N}}$} & Mesosetum alatum Filg. & RCO 2765 & $2 \mathrm{n}=8$ & $2 \mathrm{x}$ & 3,6284 & 1,8142 & 0,4536 \\
\hline & $\begin{array}{l}\text { Mesosetum ansatum } \\
\text { (Trin.) Kuhlm. }\end{array}$ & RCO 2766 & $2 n=8$ & $2 \mathrm{x}$ & 2,1264 & 1,0632 & 0,2658 \\
\hline
\end{tabular}


$\begin{array}{lllllll}\text { Mesosetum ansatum } & \text { RCO } 2784 & 2 \mathrm{n}=8 & 2 \mathrm{x} & 2,1336 & 1,0668 & 0,2667\end{array}$

(Trin.) Kuhlm.

\begin{tabular}{|c|c|c|c|c|c|c|}
\hline $\begin{array}{l}\text { Mesosetum bifarium } \\
\text { (Hack.) Chase }\end{array}$ & V 15927 & $2 n=8$ & $2 \mathrm{x}$ & 3,0236 & 1,5118 & 0,3780 \\
\hline $\begin{array}{l}\text { Mesosetum bifarium } \\
\text { (Hack.) Chase }\end{array}$ & V 15933 & $2 \mathrm{n}=8$ & $2 \mathrm{x}$ & 3,1131 & 1,5566 & 0,3891 \\
\hline $\begin{array}{l}\text { Mesosetum bifarium } \\
\text { (Hack.) Chase }\end{array}$ & ASS 235 & $2 n=16$ & $4 \mathrm{x}$ & 4,8023 & 1,2006 & 0,3001 \\
\hline Mesosetum chaseae Luces & RCO 2772 & $2 n=24$ & $6 x$ & 5,7903 & 0,9651 & 0,2413 \\
\hline $\begin{array}{l}\text { Mesosetum compressum } \\
\text { Swallen }\end{array}$ & ASS 274 & $2 \mathrm{n}=16$ & $4 x$ & 5,1935 & 1,2984 & 0,3246 \\
\hline $\begin{array}{l}\text { Mesosetum elytrochaetum } \\
\text { (Hack.) Swallen }\end{array}$ & AROR 377 & $2 n=24$ & $6 x$ & 9,0172 & 1,5029 & 0,3757 \\
\hline $\begin{array}{l}\text { Mesosetum loliiforme } \\
\text { (Hochst. ex Steud.) Chase }\end{array}$ & AROR 355 & indet. & - & 5,3743 & - & - \\
\hline
\end{tabular}

Num. crom.: Número cromossômico (Indet.: Número cromossômico não determinado).

Nível Ploid.: Nível de Ploidia (2x: diploide; 4x: tetraploide; 6x: hexaploide). 


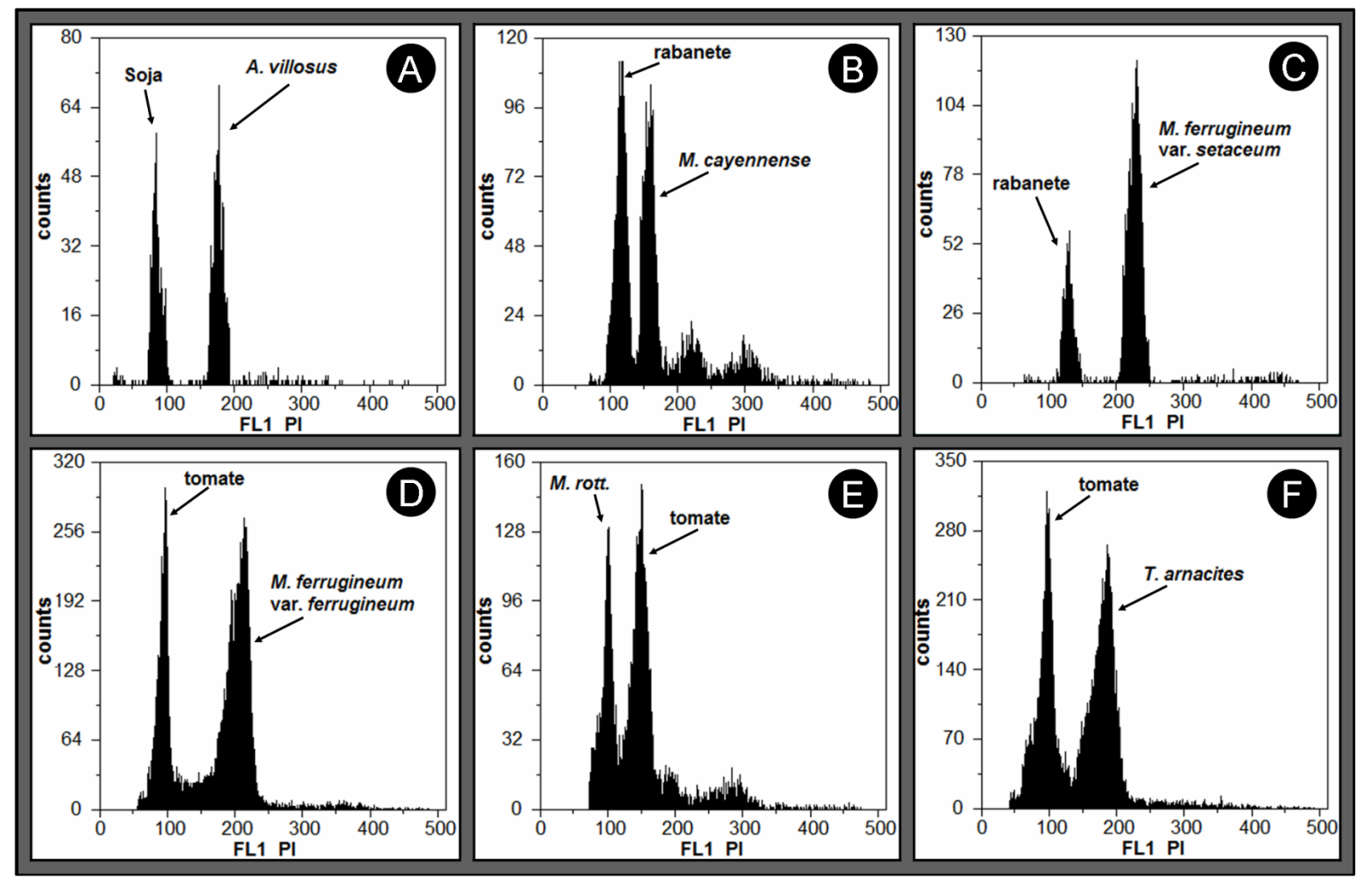

Figura 1. Histogramas das quantidades de DNA (2C) relativas obtidas de núcleos isolados em tecidos de folhas jovens em espécies de Arthropogoninae com número cromossômico básico $\mathrm{x}=10$. A. Arthropogon villosus, RCO 2971, 2n = 40. B. Mesosetum cayennense, AROR 362, $2 \mathrm{n}=20$. C. M. ferrugineum var. setaceum, AROR 409, $2 \mathrm{n}=20$. D. M. ferrugineum var. ferrugineum, MWSS 64, $2 \mathrm{n}=60$. E. M. rottboellioides, PAR 331, $2 \mathrm{n}=20$. F. Tatianyx arnacites, AROR 411, $2 \mathrm{n}=60$. 


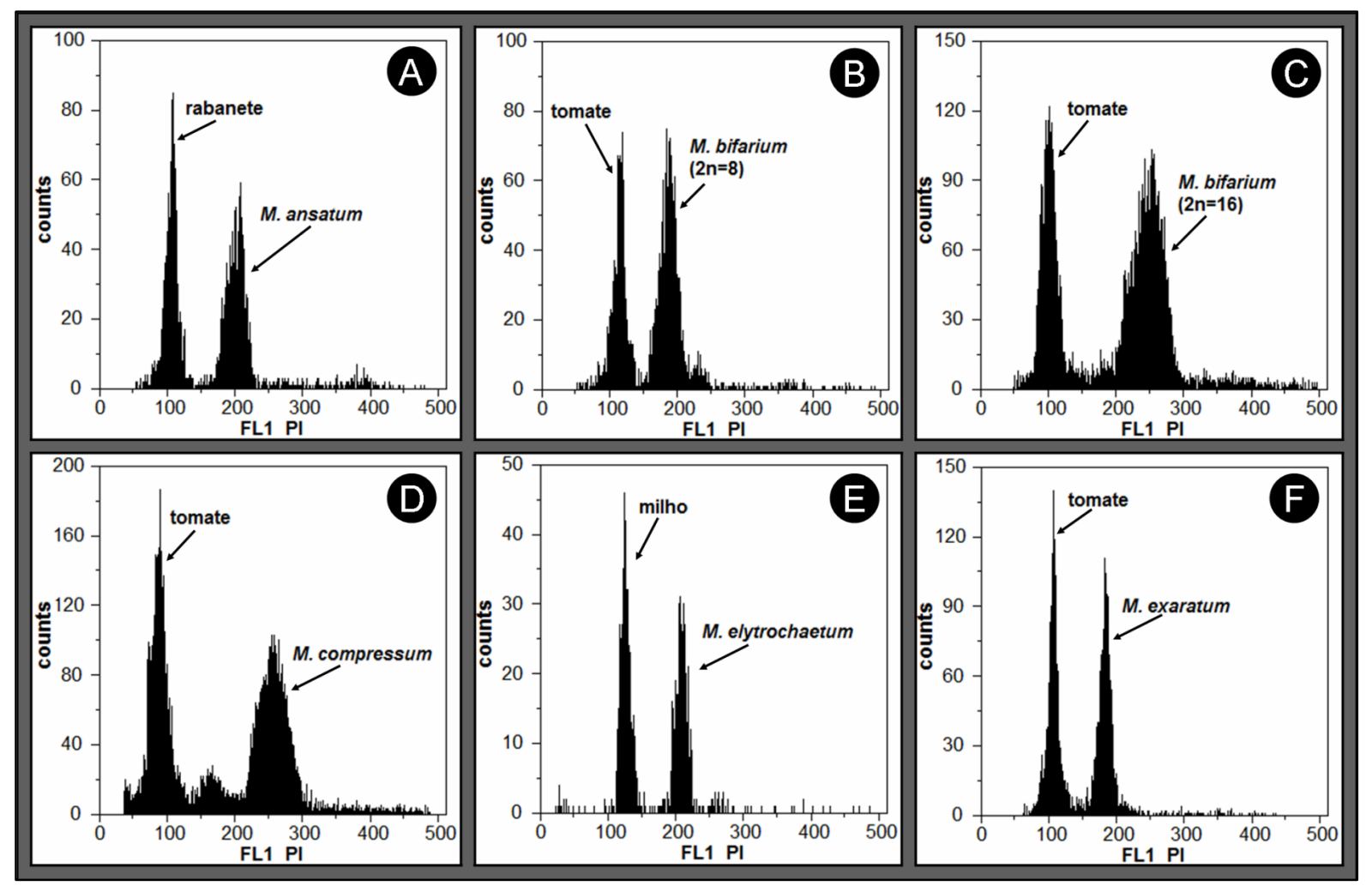

Figura 2. Histogramas das quantidades de DNA (2C) relativas obtidas de núcleos isolados em tecidos de folhas jovens em espécies de Mesosetum com números cromossômicos básicos $\mathrm{x}=$ $10 \mathrm{e} \mathrm{x}=13$. A. Mesosetum ansatum, $\mathrm{RCO} 2766,2 \mathrm{n}=8$. B-C. . . bifarium. B. V15933, $2 \mathrm{n}=$ 8. C. ASS $235,2 \mathrm{n}=16$. D. M. compressum, ASS $274,2 \mathrm{n}=16$. E. M. elytrochaetum AROR $377,2 \mathrm{n}=24$. F. $M$. exaratum, AROR $351,2 \mathrm{n}=26$.

\subsection{Discussão}

As estimativas dos tamanhos dos genomas por citometria de fluxo obtidas pelo presente trabalho são pela primeira vez determinadas nos gêneros Arthropogon, Mesosetum e Tatianyx. Os resultados obtidos pelo presente trabalho sugerem que a evolução dos genomas das linhagens se processou de forma distinta entre os genomas com número cromossômico básico $\mathrm{x}=10$ na subtribo Arthropogoninae.

O tamanho do genoma monoploide do tatraploide $(2 \mathrm{n}=40)$ de Arthropogon villosus $(\mathrm{Cx}=1,3344 \mathrm{pg})$ é até três vezes maior que os genomas dos diploides $(2 \mathrm{n}=20)$ de Mesosetum cayennense (Cx variando entre 0,4425 pg e 0,7586 pg), M. ferrugineum var. setaceum $(\mathrm{Cx}=$ $0,9728 \mathrm{pg})$ e $M$. rottboellioides $(\mathrm{Cx}=0,6448 \mathrm{pg})$. O genoma do tetraploide $(2 \mathrm{n}=40)$ de Arthropogon villosus $(2 \mathrm{C}=5,3375 \mathrm{pg})$ chega a ser maior até mesmo que os genomas dos 
hexaploides $(2 \mathrm{n}=60)$ de Tatianyx arnacites $(2 \mathrm{C}=3,5951 \mathrm{pg})$ e Mesosetum ferrugineum var. ferrugineum $(2 \mathrm{C}=4,6079 \mathrm{pg})$.

Esta diferença de tamanho entre os genomas sugere que a tendência ou linhagem evolutiva de Arthropogon é provavelmente diferente em relação aos dois outros gêneros aqui estudados. Enquanto em A. villosus provavelmente houve tendência de aumento no tamanho do genoma, nos outros gêneros de Paspaleae, como Mesosetum, Paspalum e Tatianyx o genoma manteve-se conservado pequeno na maioria das espécies com $\mathrm{x}=10$ (Vaio et al. 2007; Leitch et al. 2010; Galdeano et al. 2016). A análise de outras espécies de Arthropogon deve ser investida para melhor compreender esta tendência.

Já o tamanho do genoma do hexaploide $(2 \mathrm{n}=60)$ de Tatianyx $(\mathrm{Cx}=0,5992 \mathrm{pg})$ é quase equivalente ao genoma do diploide $(2 \mathrm{n}=20)$ de $M$. rottboellioides $(\mathrm{Cx}=0,6448 \mathrm{pg})$. Esta equivalência do tamanho dos genomas suporta o clado proposto por Morrone et al. (2012). Os resultados sugerem ainda que o ancestral do clado composto por Keratochlaena, Mesosetum e Tatianyx tinha uma baixa quantidade de DNA.

Embora os dados indiquem que o genoma do ancestral era pequeno no clado Keratochlaena, Mesosetum e Tatianyx houve um aumento do genoma subseqüente no clado $\mathrm{x}$ = 10. Essa tendência pode ser verificada na comparação com $M$. ferrugineum. $\mathrm{O}$ tamanho do genoma do hexaploide $(2 \mathrm{n}=60)$ de $T$. arnacites $(2 \mathrm{C}=3,5951 \mathrm{pg})$ foi inferior ao acesso do também hexaploide $(2 \mathrm{n}=60)$ de $M$. ferrugineum var. ferrugineum $(2 \mathrm{C}=4,6079 \mathrm{pg})$.

Dentro de Mesosetum, observou-se correspondência da quantidade de DNA com o tamanho dos cromossomos e o nível de ploidia reportados por Ribeiro (2013), Sousa (2014) e Ribeiro et al. (2015). Nos poliploides dos clados $\mathrm{x}=10$ e $\mathrm{x}=4$ foram observadas relativas perdas de DNA em comparação com os diploides. Esta redução de DNA após a poliploidização está relacionada à perda de cópias redundantes de genes, o que já foi reportado em vários gêneros de Poaceae e Panicoideae (Langham et al. 2004; Paterson et al. 
2004; Murat et al. 2010; Schnable et al. 2012). Além disso, os acessos do presente estudo de citometria também foram utilizados na filogenia molecular do gênero Mesosetum (Silva dados não publicados) o que permitiu avaliar como o genoma evoluiu entre as distintas espécies do gênero.

O tamanho do genoma diploide das espécies do clado $\mathrm{x}=10$, que provavelmente é mais basal em Mesosetum (Silva dados não publicados), é até quatro vezes menor que o genoma diploide das espécies de Mesosetum com $\mathrm{x}=4$ e $\mathrm{x}=13$. Estes resultados indicam que provavelmente houve incremento no tamanho do genoma nas espécies com números $\mathrm{x}=4$ e $\mathrm{x}$ $=13$ após sua origem a partir de um ancestral com $\mathrm{x}=10$. Esta expansão do genoma também é evidenciada pelos cromossomos maiores e com maior quantidade média de cromatina acumulada em cada cromossomo nas espécies com $\mathrm{x}=4(3,7-7,2 \mu \mathrm{m} ; 0,24-0,45 \mathrm{pg}) \mathrm{e}$ também com $\mathrm{x}=13(2,5-5,0 \mu \mathrm{m} ; 0,13 \mathrm{pg})$ em comparação às espécies com $\mathrm{x}=10(1,8-4,0$ $\mu \mathrm{m} ; 0,04-0,010$ pg) (Capítulo 1 desta tese).

No clado das espécies com $\mathrm{x}=10$, o tamanho do genoma dos diploides $(2 \mathrm{n}=20)$ variou entre $2 \mathrm{C}=0,8850 \mathrm{pg}$ e $2 \mathrm{C}=1,9456 \mathrm{pg}$ em $M$. cayennense, $M$. ferrugineum var. setaceum e M. rottboellioides. Estas quantidades de DNA foram as menores observadas entre todas as espécies analisadas. O genoma menor pode ser explicado pelo tamanho reduzido dos cromossomos que medem entre 1,8 e 4,0 $\mu \mathrm{m}$ (Capítulo 1 desta tese; Sousa 2014), o que reflete uma menor quantidade de cromatina acumulada em cada cromossomo $(2 \mathrm{C} / 2 \mathrm{n}$ entre 0,0443 pg e 0,0973 pg).

Em outros gêneros de Panicoideae, genomas com tamanhos semelhantes aos das espécies de Mesosetum foram reportados em espécies com números cromossômicos idênticos $(2 \mathrm{n}=20)$ ou menores $(2 \mathrm{n}=10)$ (Price et al. 2005; Vaio et al. 2007).

No gênero Paspalum L., em espécies dos grupos Paniculata e Quadrifaria foram registrados genomas de citótipos diploides com $2 \mathrm{n}=20$ cromossomos (Vaio et al. 2007) 
muito próximos aos aqui observados em Mesosetum. Em P. haumanii Parodi $(2 \mathrm{C}=1,50$ pg), P. intermedium Munro ex Morong \& Britton $(2 \mathrm{C}=1,51 \mathrm{pg})$, P. juergensii Hack. $(2 \mathrm{C}=1,24$ pg) e P. quadrifarium Lam. $(2 \mathrm{C}=1,87 \mathrm{pg})$ as quantidades de DNA reportadas por Vaio et al. (2007) foram muito similares às observadas em $M$. cayennense $(2 \mathrm{C}=1,5171 \mathrm{pg}), M$. ferrugineum var. setaceum $(2 \mathrm{C}=1,9456 \mathrm{pg})$ e $M$. rottboellioides $(2 \mathrm{C}=1,2895 \mathrm{pg})$.

No gênero Sorghum Moench resultados semelhantes foram obtidos para S. bicolor (L.) Moench $(2 \mathrm{C}=1,67 \mathrm{pg})$ e S. propinquum (Kunth) Hitchc. $(2 \mathrm{C}=1,51 \mathrm{pg})$, ambas com $2 \mathrm{n}=20$ cromossomos (Price et al. 2005). Entretanto, o tamanho do genoma de S. nitidum (Vahl) Pers. $(2 \mathrm{C}=8,79 \mathrm{pg})$ também com $2 \mathrm{n}=20$ cromossomos (Price et al. 2005) é até sete vezes maior que o genoma das espécies de Mesosetum com mesmo número cromossômico. Com base na filogenia de Sorghum, esta diferença de tamanho do genoma é atribuída ao fato de $2 \mathrm{n}=20$ cromossomos ter múltiplas origens durante a evolução cromossômica do gênero Sorghum (Price et al. 2005).

De acordo com a filogenia do gênero Mesosetum proposta por Silva (dados não publicados), M. ferrugineum compõe um clado fortemente suportado com $M$. cayennense e $M$. rottboellioides. Assim é possível estabelecer comparações entre as espécies de Mesosetum $\operatorname{com} x=10$.

É bastante provável que o hexaploide $(2 \mathrm{n}=60)$ M. ferrugineum var. ferrugineum surgiu por poliploidia a partir do diploide $(2 \mathrm{n}=20)$ M. ferrugineum var. setaceum. A quantidade de DNA monoploide obtida no hexaploide $(2 \mathrm{n}=60)$ de $M$. ferrugineum var. ferrugineum $(\mathrm{Cx}=0,7680 \mathrm{pg})$ é menor que no diploide representado por $M$. ferrugineum var. setaceum $(\mathrm{Cx}=0,9728 \mathrm{pg})$, sugerindo que houve perda de DNA após o evento de poliploidização. A perda de DNA normalmente se processa associada à diploidização (Langham et al. 2004; Paterson et al. 2004; Murat et al. 2010; Schnable et al. 2012). Entretanto, em M. ferrugineum, a ausência de informações sobre a meiose impossibilita 
verificar se houve uma estabilização do pareamento em bivalentes no poliploide $\operatorname{com} 2 \mathrm{n}=60$ cromossomos. Vale salientar que esta espécie floresce apenas após incêndios em habitat natural e ainda não houve sucesso na indução de florescimento em ambientes cultivados, impossibilitando os estudos de meiose.

As espécies com número cromossômico básico $\mathrm{x}=4$ na filogenia molecular de Mesosetum (Silva dados não publicados) compõe um clado que pode ser subdividido em subclados principais altamente suportados que corroboram com os dados de citometria de fluxo do presente trabalho. Há um subclado monoespecífico que agrupa os dois acessos diploides de $M$. ansatum $\operatorname{com} 2 \mathrm{n}=8$ cromossomos (Ribeiro 2013 e Ribeiro et. al. 2015; Silva dados não publicados). Há outro subclado entre as espécies com $\mathrm{x}=4$ composto por $M$. alatum, M. bifarium, M. chaseae, M. compressum e M. elytrochaetum (Silva dados não publicados).

O tamanho do genoma de M. ansatum (2C entre 2,1264 pg e 2,1336 pg) é no mínimo $30 \%$ menor que os genomas de outras espécies diploides $(2 \mathrm{n}=8)$ do subclado irmão $(2 \mathrm{C}$ entre 3,0236 pg e 3,6284 pg). Estes resultados indicam que há pelo menos duas linhagens distintas na evolução genômica das espécies com $\mathrm{x}=4$.

Foram examinados 3 citótipos de $M$. bifarium, os dois primeiros, representados pelos acessos V15927 e V 15933 diploides $(2 \mathrm{n}=8)$, e o terceiro, representado pelo acesso ASS 235 tetraploide natural $(2 \mathrm{n}=16)$. A quantidade de DNA monoploide da planta tetraploide ASS $235(\mathrm{Cx}=1,2006 \mathrm{pg})$ é inferior à observada nas plantas diploides $(\mathrm{Cx}$ entre 1,5118 pg e $1,5566 \mathrm{pg})$. Estes dados sugerem que houve perda de DNA no acesso tetraploide $(2 \mathrm{n}=16)$ após o processo de poliploidização. Esta perda de DNA está relacionada à diploidização comprovada na estabilidade da meiose do tetraploide ASS 235, que apresentou pareamento predominante em bivalentes em mais de $86 \%$ das diacineses examinadas (Ribeiro 2013). 
O mesmo parece ter ocorrido com $M$. compressum que também está no mesmo subclado de $M$. bifarium. O tamanho do genoma monoploide do tetraploide $(2 \mathrm{n}=16)$ de $M$. compressum $(\mathrm{Cx}=1,2984 \mathrm{pg})$ é inferior ao observado nos diploides $(2 \mathrm{n}=8)$ de $M$. bifarium (Cx entre 1,5118 pg e 1,5566 pg). A meiose estável de M. compressum mostra que a perda de genes e a redução do genoma também ocorreu paralela ao processo de diploidização comprovada na meiose estável com mais de 90\% das diacineses com pareamento em bivalentes.

O acesso hexaploide $(2 \mathrm{n}=24)$ de $M$. elytrochaetum forma um clado altamente suportado com os dois acessos diploides de M. bifarium (Silva dados não publicados). A quantidade de DNA monoploide do hexaploide natural $(2 \mathrm{n}=24)$ de M. elytrochaetum $(\mathrm{Cx}=$ $1,5029 \mathrm{pg}$ ) é quase equivalente à observada nos diploides de $M$. bifarium $(\mathrm{Cx}$ entre 1,5118 pg e 1,5566 pg). Estes resultados indicam que o tamanho do genoma de M. elytrochaetum manteve-se praticamente estável após o processo de poliploidização, com pequena perda de DNA.

Em M. loliiforme foram examinados três acessos, porém foram obtidos picos bem definidos apenas no acesso AROR 355. Provavelmente, a espécie deve apresentar compostos bioquímicos que interferem na fluorescência dos núcleos e nos resultados obtidos, sendo necessário ajustar uma solução tampão mais adequada. A única planta examinada com sucesso apresentou $2 \mathrm{C}=5,3743 \mathrm{pg}$. Devido à ausência de florescimento, foram coletadas raízes para análise dos cromossomos em mitose. Porém não houve sucesso e as mudas de $M$. loliiforme por serem mais sensíveis não sobreviveram à coleta de raízes.

A linhagem monoespecífica de $M$. exaratum com número cromossômico básico $\mathrm{x}=13$ representa uma linha evolutiva bastante peculiar. A ausência deste número cromossômico (2n = 26) em outras Panicoideae ou mesmo outras espécies de Mesosetum limita a comparação dos resultados obtidos. Em Mesosetum o número cromossômico mais próximo é $2 \mathrm{n}=20$. A 
quantidade média de DNA por cromossomo observada em $M$. exaratum $(2 \mathrm{C} / 2 \mathrm{n}=0,1278 \mathrm{pg})$ é até quase 3 vezes maior que nos diploides com $x=10(2 \mathrm{C} / 2 \mathrm{n}$ variando entre $0,0443 \mathrm{pg}$ e 0,0973 pg). Estes resultados indicam que houve aumento do tamanho do genoma após a origem do número cromossômico básico $\mathrm{x}=13$ a partir de $\mathrm{x}=10$. Esta expansão do genoma está estritamente associada ao tamanho dos cromossomos de $M$. exaratum que são maiores que os observados nos diploides com $\mathrm{x}=10$ (Sousa 2014; Capítulo 1).

\subsection{Conclusão}

A comparação dos resultados do presente estudo de citometria aliada à análise dos trabalhos de Ribeiro (2013), Sousa (2014), Ribeiro et al. (2015), Silva (dados não publicados), além dos dados do Capítulo 1 desta tese permitem elaborar algumas hipóteses para evolução do gênero Mesosetum.

É bastante provável que a linhagem mais basal do gênero Mesosetum com x $=10$ tivesse baixa quantidade de DNA e cromossomos pequenos como os observados em $M$. cayennense, M. ferrugineum e M. rottoboellioides.

Já nas espécies de Mesosetum do clado $\mathrm{x}=4$ houve ganho de DNA após sua origem a partir de cariótipo ancestral com cromossomos menores. Este expansão do tamanho do genoma refletiu no aumento do tamanho dos cromossomos do clado $\mathrm{x}=4$. Novos estudos de caracterização cromossômica, molecular e por citometria de fluxo devem ser estimuladas para se compreender a evolução das espécies de Mesosetum.

\subsection{Referências}

Adoukonou-Sagbadja H, Schubert V, Dansi A, Jovtchev G, Meister A, Pistrick K, Akpagana K, Friedt W (2007) Flow cytometric analysis reveals different nuclear DNA contents in 
cultivated Fonio (Digitaria spp.) and some wild relatives from West-Africa. Journal of Plant Research 267: 163-176

Burke SV, Wysocki WP, Zuloaga FO, Craine JM, Pires JC, Edger PP, Mayfield-Jones D, Clark LG, Kelchner SA, Duvall MR (2016) Evolutionary relationships in Panicoid grasses based on plastome phylogenomics (Panicoideae; Poaceae). BMC Plant Biology 16(140): 1-11

Celarier R, Paliwal R (1957) Basic chromosome number of four in the subfamily Panicoideae of the Gramineae. Science 126: 1247

Chae WB, Hong SJ, Gifford JM, Rayburn AL, Widholm JM, Juvik JA (2013) Synthetic polyploid production of Miscanthus sacchariflorus, Miscanthus sinensis, and Miscanthus x giganteus. Global Change Biology Bioenergy 5: 338-350

Cidade FW, Dall'Agnol M, Bered F, Souza-Chies TTd (2008) Genetic diversity of the complex Paspalum notatum Flügge (Paniceae: Panicoideae). Genetic Resources and Crop Evolution 55: 235-246

De Wet JMJ (1987) Hybridization and polyploidy in the Poaceae. In: Soderstrom TR, Hilu KW, Campbell CS, Barkworth MA (eds.) Grass systematics and evolution, Smithsonian Inst. Press., Washington DC, pp 188-194

Dolezel J, Sgorbati S, Lucretti S (1992) Comparison of three DNA fluorochromes for flow cytometric estimation of nuclear DNA content in plants. Physiologia Plantarum 85: $625-631$

Dolezel J, Greilhuber J, Lucretti S, Meister A, Lysak MA, Nardi L, Obermayer R (1998) Plant Genome Size Estimation by Flow Cytometry: Inter-laboratory Comparison. Annals of Botany 82 (Supplement A): 17-26

Dolezel J, Bartos J (2005) Plant DNA Flow Cytometry and Estimation of Nuclear Genome Size. Annals of Botany 95: 99-110 
Filgueiras TS (1986) O gênero Mesosetum Steudel (Gramineae: Paniceae). Tese de Doutorado, Universidade Estadual de Campinas, Campinas-SP, Brazil

Filgueiras TS (1989) Revisão de Mesosetum Steudel (Gramineae: Paniceae). Acta Amazônica 19: $47-114$

Filgueiras TS, Silva AS, Oliveira RC (2016) Mesosetum In Lista de Espécies da Flora do Brasil. Jardim Botânico do Rio de Janeiro, Brazil. Available at: http://floradobrasil.jbrj.gov.br/jabot/floradobrasil/FB13355, Accessed 18 Jan. 2016

Galdeano F, Urbani MH, Sartor ME, Honfi AI, Espinoza F, Quarín CL (2016) Relative DNA content in diploid, polyploid, and multiploid species of Paspalum (Poaceae) with relation to reproductive mode and taxonomy. Journal of Plant Research 129(4): 697-710

Greilhuber J, Dolezel J, Lysák MA, Bennett MD (2005) The Origin, Evolution and Proposed Stabilization of the Terms 'Genome Size' and 'C-Value' to Describe Nuclear DNA Contents. Annals of Botany 95: 255-260

Hilu K (2004) Phylogenetics and chromosomal evolution in the Poaceae (grasses). Australian Journal of Botany 52: 13-22

Hunziker JH, Stebbins GL (1987) Chromosome evolution in the Gramineae. In: Soderstrom TR, Hilu KW, Campbell CS, Barkworth MA (eds.) Grass Systematics and Evolution, Smithsonian Inst., Washington, pp 179-187

Langham RJ, Walsh J, Dunn M, Ko C, Goff SA, Freeling M (2004) Genomic duplication, fractionation and the origin of regulatory novelty. Genetics 166: 935-945

Layton DJ, Kellogg EA (2014) Morphological, phylogenetic, and ecological diversity of the new model species Setaria Viridis (Poaceae: Paniceae) and its close relatives. American Journal of Botany 101(3): 539-557

Leitch IJ, Beaulieu JM, Chase MW, Leitch AR, Fay MF (2010) Genome Size Dynamics and Evolution inMonocots. Journal of Botany ID 862516: 1-18 
Loureiro J, Rodriguez E, Dolezel J, Santos C (2007) Two New Nuclear Isolation Buffers for Plant DNA Flow Cytometry: A Test with 37 Species. Annals of Botany 100: 875-888

Morrone O, Escobar A, Zuloaga FO (2006) Chromosome studies in American Panicoideae (Poaceae). Annals of the Missouri Botanical Garden 93: 647-657

Morrone O, Aagesen L, Scataglini MA, Salariato DL, Denham SS, Chemisquy MA, Sede SM, Giussani LM, Kellogg EA, Zuloaga FO (2012) Phylogeny of the Paniceae (Poaceae: Panicoideae): integrating plastid DNA sequences and morphology into a new classification. Cladistics 28: 333-356

Murat F, Xu J-H, Tannier E, Abrouk M, Guilhot N, Pont C, Messing J, Salse J (2010) Ancestral grass karyotype reconstruction unravels new mechanisms of genome shuffling as a source of plant evolution. Genome Research 20: 1545-1557

Paterson AH, Bowers JE, Chapman BA (2004) Ancient polyploidization predating divergence of the cereals, and its consequences for comparative genomics. Proceedings of the National Academy of Sciences of the United States of America 101(26): 9903-9908

Pozzobon MT, Paganella MB, Santos S, Valls JFM (2013) Cytological and reproductive aspects in the Caespitosa group of Paspalum. Ciência Rural 43 (11): 2004-2010

Price HJ, Dillon SL, Hodnett G, Rooney WL, Ross L, Johnston JS (2005) Genome Evolution in the Genus Sorghum (Poaceae). Annals of Botany 95: 219-227

Ribeiro ARO (2013) Citogenética, reprodução e variabilidade morfológica de espécies de Mesosetum sect. Bifaria (Hack.) Chase (Poaceae: Paniceae). Dissertação de Mestrado, Universidade de Brasília, Brasília-DF, Brazil

Ribeiro ARO, Sousa MWS, Oliveira RC, Araujo ACG, Fagg CW, Pozzobon MT (2015) Cytological studies in four species of Mesosetum (Arthropogoninae) reveal the lowest chromosome number among the Neotropical Poaceae. Plant Systematics and Evolution 301(10): 2377-2386 
Schapova AI (2012) Evolution of the Basic Chromosome Number in Poaceae Barnh. Russian Journal of Genetics: Applied Research 2(3): 252-259

Schnable JC, Freeling M, Lyons E (2012) Genome-Wide Analysis of Syntenic Gene Deletion in the Grasses. Genome Biology and Evolution 4(3): 265-277

Sede S, Escobar A, Morrone O, Zuloaga FO (2010) Chromosome studies in American Paniceae (Poaceae-Panicoideae). Annals of the Missouri Botanical Garden 97: 128-138

Silva AS, Villarroel D, Ribeiro ARO, Oliveira RC (2016) Eleven new records of little known taxa of Mesosetum and Paspalum (Poaceae) from Brazil and Bolivia. Phytotaxa 268(1): 069-079

Sousa MWS (2014) Citogenética e morfologia de espécies de Mesosetum Steud. (Poaceae, Paspaleae). Dissertação de Mestrado, Universidade de Brasília, Brasília-DF, Brazil

SpeciesLink (2016) Centro de Referência em Informação Ambiental - CRIA. Available at: http://www.splink.org.br/, Accessed 1 Nov. 2016

Studer AJ, Schnable JC, Weissmann S, Kolbe AR, McKain MR, Shao Y, Cousins AB, Kellogg EA, Brutnell TP (2016) The draft genome of the C3 panicoid grass species Dichanthelium oligosanthes. Genome Biology 17(223): 1-18

Swallen JR (1937) The grass genus Mesosetum. Brittonia 2(4): 363-392

Thiers B (2016) Index Herbariorum: A global directory of public herbaria and associated staff. New York Botanical Garden's Virtual Herbarium. (Continuously Updated). Available at: http://sweetgum.nybg.org/ih/ Accessed 01 Nov. 2016

Vaio M, Mazzella C, Porro V, Speranza P, López-Carro B, Estramil E, Folle GA (2007) Nuclear DNA content in allopolyploid species and synthetic hybrids in the grass genus Paspalum. Plant Systematics and Evolution 265: 109-121 
Wang X, Wang J, Jin D, Guo H, Lee T-H, Liu T, Paterson AH (2015) Genome Alignment Spanning Major Poaceae Lineages Reveals Heterogeneous Evolutionary Rates and Alters Inferred Dates for Key Evolutionary Events. Molecular Plant 8: 885-898 


\section{CAPÍTULO 3}

Estudos de citogenética molecular em espécies de Mesosetum sect. Bifaria (Hack.) Chase

(Poaceae: Arthropogoninae) 


\subsection{Introdução}

As técnicas de citogenética molecular com hibridização in situ fluorescente (sigla FISH - Fluorescence In Situ Hybridization) têm sido úteis para distinção cariotípica e estudo da evolução genômica de poliploides em Poaceae (Cremonini et al. 2003, Kotseruba et al. 2003, 2005, Cremonini 2005, Vaio et al. 2005, Kim et al. 2009, Nielen et al. 2010; Amosova et al. 2015). As sequências repetitivas de DNA ribossômico (DNAr), os loci para o DNAr 5S e DNAr 45S, podem ser identificados em um ou mais sítios com posições características, fornecendo marcas que caracterizam cromossomos ou cariótipos (Cremonini et al. 2003, Kotseruba et al. 2003, Cremonini 2005; Vaio et al. 2005, Nielen et al. 2010).

Apesar desta ferramenta já ter sido empregada em várias gramíneas de uso agronômico (Jiang \& Gill 1994, Shishido et al. 2000, Sang \& Liang, 2000, Brasileiro-Vidal et al. 2003, Harper et al. 2004, Ferrari 2010), raros são os trabalhos utilizando FISH em gramíneas nativas. Entre os estudos com enfoque citotaxonômico para Paniceae s.l. nativas destacam-se os de Vaio et al. (2005) e Santos (2007).

O trabalho de Vaio et al. (2005) forneceu parâmetros para a distinção de espécies de Paspalum L. grupo Quadrifaria, a caracterização de diferentes versões do genoma I e permitiu propor eventos de hibridação entre diferentes espécies do grupo. Santos (2007) verificou em Axonopus ser. Suffulti G.A. Black caracteres nas bandas CMA/DAPI para distinção das espécies e também a duplicação dos sítios de DNAr 45S em poliploides.

O reconhecimento dos pares cromossômicos pela presença de sítios de DNAr $5 \mathrm{~S}$ e $45 \mathrm{~S}$ é ainda mais eficiente na caracterização do complemento genômico básico de gramíneas com número cromossômico baixo (Cremonini et al. 2003, Kotseruba et al. 2003, 2005, Cremonini 2005; Kotseruba et al. 2010).

Nas espécies Colpodium versicolor (Steven) Schmalh. e Zingeria biebersteiniana (Claus) P.A. Smirn., subfamília Pooideae, tribo Poeae, foi encontrado $2 \mathrm{n}=4$, o qual é menor 
número cromossômico já registrado em Poaceae. O número cromossômico $2 \mathrm{n}=4(\mathrm{x}=2)$ também é o menor já observado entre as angiospermas, sendo registrado somente nas famílias Asteraceae, Cyperaceae e Poaceae (Cremonini et al. 2003, Michelan et al. 2012).

Na tribo Poeae, o número cromossômico básico $\mathrm{x}=7$ é considerado o mais basal e predomina na maioria de suas espécies, a partir do qual o número cromossômico $2 \mathrm{n}=4$ ( $\mathrm{x}=$ 2) derivou-se por fusão e rearranjos (Cremonini et al. 2003; Kotseruba et al. 2003, 2005; Kim et al. 2009; Kotseruba et al. 2010). A partir de estudos moleculares combinados com ensaios de FISH e GISH (Genome In Situ Hybridization), foi possível verificar que Zingeria biebersteiniana (Claus) P.A. Smirn. $(2 \mathrm{n}=4, \mathrm{x}=2)$ originou por alopoliploidia o genoma com $2 \mathrm{n}=8$ cromossomos de Z. trichopoda (Boiss.) P.A. Smirn. Foram observados dois sítios de 5S no Z. biebersteiniana $(2 \mathrm{n}=4)$ e 4 sítios de $5 \mathrm{~S}$ em $Z$. trichopoda $(2 \mathrm{n}=8)$ o que comprovou o nível diploide em $2 \mathrm{n}=4(\mathrm{x}=2)$ e nível alotetraploide em $2 \mathrm{n}=8$.

Na subfamília Panicoideae, as mudanças do cariótipo também estão diretamente relacionadas com a evolução do genoma de suas espécies (Hilu 2004; Leitch et al. 2010; Murat et al. 2010; Burke et al. 2016; Studer et al. 2016). Há grande diversidade de números cromossômicos em Panicoideae, com predomínio de múltiplos de $\mathrm{x}=5, \mathrm{x}=9$ e $\mathrm{x}=10$ (Hilu 2004; Murat et al. 2010; Studer et al. 2016). Não obstante, também já foram registrados números cromossômicos básicos mais raros como $\mathrm{x}=4$ em Panicoideae (Celarier \& Paliwal 1957; Rao 1975; De Wet 1987; Morrone et al. 2012; Ribeiro 2013; Sousa 2014; Ribeiro et al. 2015). O gêneros Iseilema Anderson. (tribo Andropogoneae) e Mesosetum Steud. (tribo Paspaleae) são os únicos gêneros de Panicoideae com registro do número cromossômico básico $\mathrm{x}=4$ cuja origem ainda não foi plenamente elucidada.

$\mathrm{O}$ número cromossômico $2 \mathrm{n}=8(\mathrm{x}=4)$ encontrado em Mesosetum é o menor já observado na tribo Paspaleae e entre todas as gramíneas neotropicais (Ribeiro 2013; Sousa 2014; Ribeiro et al. 2015). O número cromossômico 2 n $=8$ já foi observado em seis espécies 
dispersas entre as seções Bifaria (Hack.) Chase e Loliiformia Swallen: M. alatum Filg., M. annuum Swallen, M. ansatum (Trin.) Kuhlm., M. bifarium (Hack.) Chase, M. longiaristatum Filg., M. pappophorum (Nees) Kuhlm. (Ribeiro 2013; Sousa 2014; Ribeiro et al. 2015; Capítulo 1 desta tese).

De acordo com Filgueiras (1986, 1989), Ribeiro (2013) e Silva et al. (2015), Mesosetum sect. Bifaria (Hack.) Chase contém sete espécies e forma um grupo homogêneo morfologicamente, sendo reconhecido pelas inflorescências com ráquis alada, espiguetas com achatamento lateral e gluma inferior aristada e/ou mucronada. Apesar de a seção ser prontamente reconhecida pelos caracteres morfológicos, a delimitação entre suas espécies é complexa pelo alto nível de semelhança morfológica compartilhado por elas.

Estudos com enfoque citotaxonômico na seção Bifaria encontraram números cromossômicos $2 n=8,16$ e 24 e observaram indícios de poliploidia na evolução de suas espécies (Ribeiro 2013; Ribeiro et al. 2015).

A filogenia baseada em dados moleculares no gênero Mesosetum combinada a estudos citogenéticos mostra que o número cromossômico $\mathrm{x}=10$ é provavelmente mais basal no gênero, a partir do qual derivou-se por redução o número básico $x=4$ (Silva dados não publicados; Capítulo 1 desta tese).

Uma redução abrupta de $\mathrm{x}=10$ para $\mathrm{x}=4$ por perda de 6 pares cromossômicos é pouco provável, pois comprometeria mais da metade do genoma original afetando genes e codificação de proteínas (Capítulo 1 desta tese). A hipótese de fusão e rearranjos cromossômicos é mais plausível para origem do número básico $\mathrm{x}=4$ a partir de $\mathrm{x}=10$ (Capítulo 1 desta tese). Entretanto ainda é desconhecida a composição e estrutura da cromatina dos cromossomos dos diploides $(2 \mathrm{n}=8)$. Também é desconhecido qual mecanismo se processou durante a poliploidização, que originou os números cromossômicos 2 n $=16$ e $2 n$ $=24$ e se ocorreram mudanças estruturais nos poliploides. 
O objetivo do Capítulo 3 desta tese de doutorado foi caracterizar por meio da técnica de hibridização in situ FISH os cromossomos de espécies de $M$. sect. Bifaria em distintos níveis de ploidia, visando ampliar o conhecimento acerca da evolução e origem do número cromossômico básico x $=4$ em Mesosetum.

\subsection{Material e Métodos}

Obtenção de metáfases mitóticas e lâminas

As mudas de quatro acessos (Tabela 1) de Mesosetum ansatum (Trin.) Kuhlm., M. chaseae Luces, M. compressum Swallen e M. elytrochaetum (Hack.) Swallen foram cultivadas na casa de vegetação do Laboratório de Citogenética Vegetal, Universidade Federal de Pernambuco.

Tabela 1. Espécies de Mesosetum e respectivos acessos caracterizados via citogenética molecular

\begin{tabular}{lccc}
\hline Espécie & Acesso & $\begin{array}{c}\text { Número } \\
\text { cromossômico }\end{array}$ & Local de Coleta \\
\hline $\begin{array}{l}\text { Mesosetum ansatum } \\
\text { (Trin.) Kuhlm. }\end{array}$ & RCO 2766 & $2 \mathrm{n}=8$ & Brasil, Mato Grosso, Poconé \\
$\begin{array}{l}\text { Mesosetum chaseae Luces } \\
\begin{array}{l}\text { Mesosetum compressum } \\
\text { Swallen }\end{array}\end{array}$ & ASS 274 2772 & $2 \mathrm{n}=24$ & Brasil, Mato Grosso, Poconé \\
$\begin{array}{l}\text { Mesosetum elytrochaetum } \\
\text { (Hack.) Swallen }\end{array}$ & AROR 377 & $2 \mathrm{n}=16$ & Brasil, Pernambuco, Pesqueira \\
\hline
\end{tabular}

Para a obtenção de metáfases mitóticas os ensaios foram baseados e adaptados dos protocolos de Pedrosa et al. (2002) e Sousa et al. (2012). As pontas de raízes foram coletadas e pré-tratadas com solução antimitótica de 8 -hidroxiquinoleina $2 \mathrm{mM}$ por $20 \mathrm{~h}$ a $10^{\circ} \mathrm{C}$ e fixadas em solução 3:1 (metanol: ácido acético, v/v) em temperatura ambiente por pelo menos $2 \mathrm{~h}$ e depois armazenadas a $-20^{\circ} \mathrm{C}$. O meristema foi previamente amolecido com enzima pectinase-celulase $20-2 \%$ por 90 min a $37{ }^{\circ} \mathrm{C}$. As lâminas foram preparadas com ácido acético $60 \%$ e a secagem foi feita sobre placa aquecedora em temperatura de $50-55^{\circ} \mathrm{C}$, conforme o protocolo de Ruban et al. (2014). As melhores lâminas com pelo menos 10 
metáfases espalhadas permitindo a distinção dos cromossomos foram selecionadas sob microscopia em contraste de fase do Microscópio LEICA para realização da hibridização.

As lâminas selecionadas foram envelhecidas por no mínimo 3 dias, no escuro, e seguiram para a FISH (Fluorescence In Situ Hybridization) com base no protocolo de Pedrosa et al. (2002).

\section{$\underline{\text { Sondas, mistura de hibridização, anticorpos e fluorocromos }}$}

Duas sondas foram utilizadas na hibridização in situ, a primeira sonda para localizar os sítios de DNA ribossômico (DNAr) $5 \mathrm{~S}$ e a segunda, para os sítios de DNAr 45S nos cromossomos. A primeira sonda foi obtida a partir de um clone do plasmídeo D2 contendo fragmento de 500 bp incluindo o gene 5S de DNA ribossômico (DNAr) de Lotus japonicus (Regel) K. Larsen, conforme descrito por Pedrosa et al. (2002). A segunda sonda foi obtida a partir do plasmídeo pTa71 contendo fragmento de $9 \mathrm{~kb}$ incluindo os genes $18 \mathrm{~S}-25 \mathrm{~S}-5.8 \mathrm{~S}$ de DNAr de Triticum aestivum L., conforme descrito por Gerlach \& Bedbrook (1979). Ambas as sondas foram marcadas com Nick Translation Mix (Roche), a sonda de DNAr 5S com Cy3dUTP (Roche) e a sonda de DNAr 45S com digoxigenina-11-dUTP (Roche). A digoxigenina da sonda de DNAr 45 foi detectada pois dois anticorpos: o primário antidigoxigenina conjugado com FITC obtido de ovelha (Roche 1207741) e o secundário anti-ovelha conjugado com FITC obtido de macaco (Serotec Star88F). Na hibridização in situ dos cromossomos, o fluorocromo Cy3 emite sinal de coloração alaranjada nos sítios de DNAr 5S e o fluorocromo FITC emite sinal de coloração esverdeada aos sítios de DNAr 45S.

A mistura de hibridização definiu estringência de 76\% para a FISH e foi preparada contendo formamida $50 \%(\mathrm{v} / \mathrm{v})$, sulfato de dextrano $10 \%(\mathrm{~m} / \mathrm{v})$, tampão SSC (cloreto de sódio, citrato de sódio) em concentração final $2 \mathrm{X}$ e as duas sondas a $5 \mathrm{ng} / \mu \mathrm{L}$. A FISH seguiu 4 etapas: pré-tratamento, hibridização, lavagem e detecção. 


\section{Etapas da hibridização}

No pré-tratamento, as lâminas foram encubadas com solução de RNase (100 $\mu \mathrm{g} / \mathrm{mL})$ por $1 \mathrm{~h}$ a $37^{\circ} \mathrm{C}$ e lavadas 3 vezes com SSC $2 \mathrm{X}$ por 5 minutos. Em seguida, as lâminas foram encubadas por $20 \mathrm{~min}$, a $37^{\circ} \mathrm{C}$, com $100 \mu \mathrm{L}$ de solução de pepsina a $10 \mu \mathrm{g} / \mathrm{mL}$ (diluída em HCL $0,01 \mathrm{~N}$ ) e lavadas 3 vezes com SSC $2 \mathrm{X}$ por 5 minutos. Posteriormente as lâminas foram fixadas por 10 min em solução de formaldeído 3,7\% (v/v) diluído em tampão PBS (fosfato salino) em concentração final $1 \mathrm{X}$ e lavadas 3 vezes com SSC $2 \mathrm{X}$ por 5 minutos. Após a fixação, as lâminas foram desidratadas em série alcoólica por 3 min em etanol $70 \%$ e 3 min em etanol 100\%. Posteriormente, as lâminas foram secas ao ar por pelo menos $1 \mathrm{~h}$.

$\mathrm{Na}$ hibridização, as lâminas receberam $10 \mu \mathrm{L}$ da solução de hibridização e desnaturadas em termociclador com adpatador para hibridização in situ a $94^{\circ} \mathrm{C}$ por $90 \mathrm{~s}$. Imediatamente após a desnaturação, as lâminulas foram vedadas nas bordas com cola plástica de PVC e encubadas em câmara umida a $37^{\circ} \mathrm{C}$ em overnigth.

As lavagens pós-hibridização foram feitas em tampão SSC. A $1^{\text {a }}$ lavagem foi feita em SSC $2 \mathrm{X}$ a temperatura ambiente por 5 min e as lamínulas removidas cuidadosamente. A $2^{\mathrm{a}}$ lavagem foi feita em SSC $2 \mathrm{X}$ por 5 min a $42^{\circ} \mathrm{C}$. A $3^{\mathrm{a}}$ e $4^{\mathrm{a}}$ lavagens foram feitas em SSC $0,1 \mathrm{X}$ por $5 \mathrm{~min}$. A $4^{\mathrm{a}}$ lavagem foi feita com SSC $2 \mathrm{X}$ por $5 \mathrm{~min}$ a $42^{\circ} \mathrm{C}$ e a $5^{\mathrm{a}}$ lavagem com SSC $2 \mathrm{X}$ a temperatura ambiente por $10 \mathrm{~min}$.

Para detecção imunológica, as lâminas foram encubadas a $37^{\circ} \mathrm{C}$ por 30 min em câmara úmida com $100 \mu \mathrm{L}$ de solução de albumina de soro bovino 3\% diluída em PBS 1X (BSA 3\%/PBS 1X). A seguir, as lâminas receberam $20 \mu \mathrm{L}$ de solução contendo $0,4 \mu \mathrm{L}$ do anticorpo primário e $19,6 \mu \mathrm{L}$ de BSA 3\%/PBS $1 \mathrm{X}$ e foram encubadas em câmara úmida a $37^{\circ} \mathrm{C}$ por $1 \mathrm{~h}$. Em seguida, as lâminas foram lavadas 3 vezes em solução de Tween 20 diluído a 0,1\% em PBS 1X por 5 min. Posteriormente, as lâminas receberam $20 \mu \mathrm{L}$ de solução contendo $0,2 \mu \mathrm{L}$ 
do anticorpo secundário e $19,8 \mu \mathrm{L}$ de BSA 3\%/PBS 1 X e foram encubadas em câmara úmida a $37^{\circ} \mathrm{C}$ por mais $1 \mathrm{~h}$. Em seguida, forma novamente lavadas 3 vezes em solução de Tween 20 diluído a $0,1 \%$ em PBS $1 \mathrm{X}$ por 5 min. As lâminas foram montadas com $8 \mu \mathrm{L}$ solução DAPI/Vectashield ${ }^{\circledR}$ (Vector) e as lamínulas vedadas com esmalte incolor. Para evitar desvanecimento do sinal fluorescente, lâminas foram armazenadas em condição escura a $4^{\circ} \mathrm{C}$ até a análise.

As lâminas foram observadas e fotografadas sob microscópio LEICA DMLB de epifluorescência, utilizando filtros apropriados e software LEICA Q-FISH. As imagens foram editadas utilizando-se Adobe Photoshop 12.0 (Figuras 1 e 2).

Os idiogramas (Figuras 3 e 4) foram determinados de acordo a homologia das bandas DAPI e sítios de DNAr $5 \mathrm{~S}$ e 45S. Os pares foram numerados em ordem decrescente em relação ao comprimento do braço cromossômico mais curto e tamanho cromossômico total, baseando-se em Souza et al. (2009).

\subsection{Resultados}

Foram obtidas bandas em DAPI e hibridizações de DNAr em metáfases de $M$. ansatum $(2 \mathrm{n}=8), M$. compressum $(2 \mathrm{n}=16), M$. chaseae $(2 \mathrm{n}=24)$ e $M$. elytrochaetum $(2 \mathrm{n}=$ 24). Em todos os cromossomos das espécies estudadas observou-se coloração DAPI na região pericentromérica. Em pelo menos um par de cada espécie foram observadas marcações de DNAr 5S e DNAr 45S em sítios terminais ou subterminais dos cromossomos (Figura 1, Figura 2). 


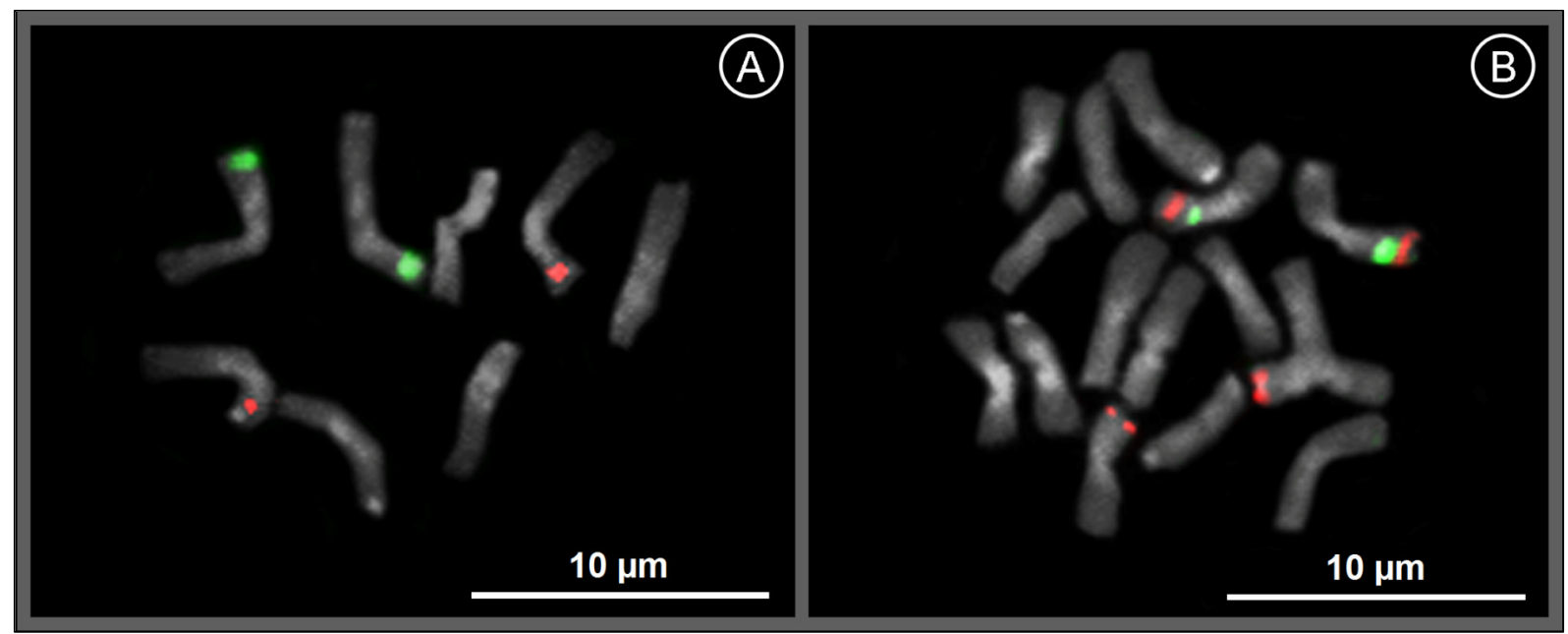

Figura 1. Metáfases mitóticas de espécies de Mesosetum sect. Bifaria com $2 n=8$ e $2 n=16$ cromossomos após hibridização in situ com DNAr 5S (fluorescente em alaranjado) e DNAr 45S (fluorescente em verde) com contracoloração em DAPI (cinza) vistas em microscópio com epifluorescência. A. M. ansantum (RCO 2766). B. M. compressum (ASS 274).

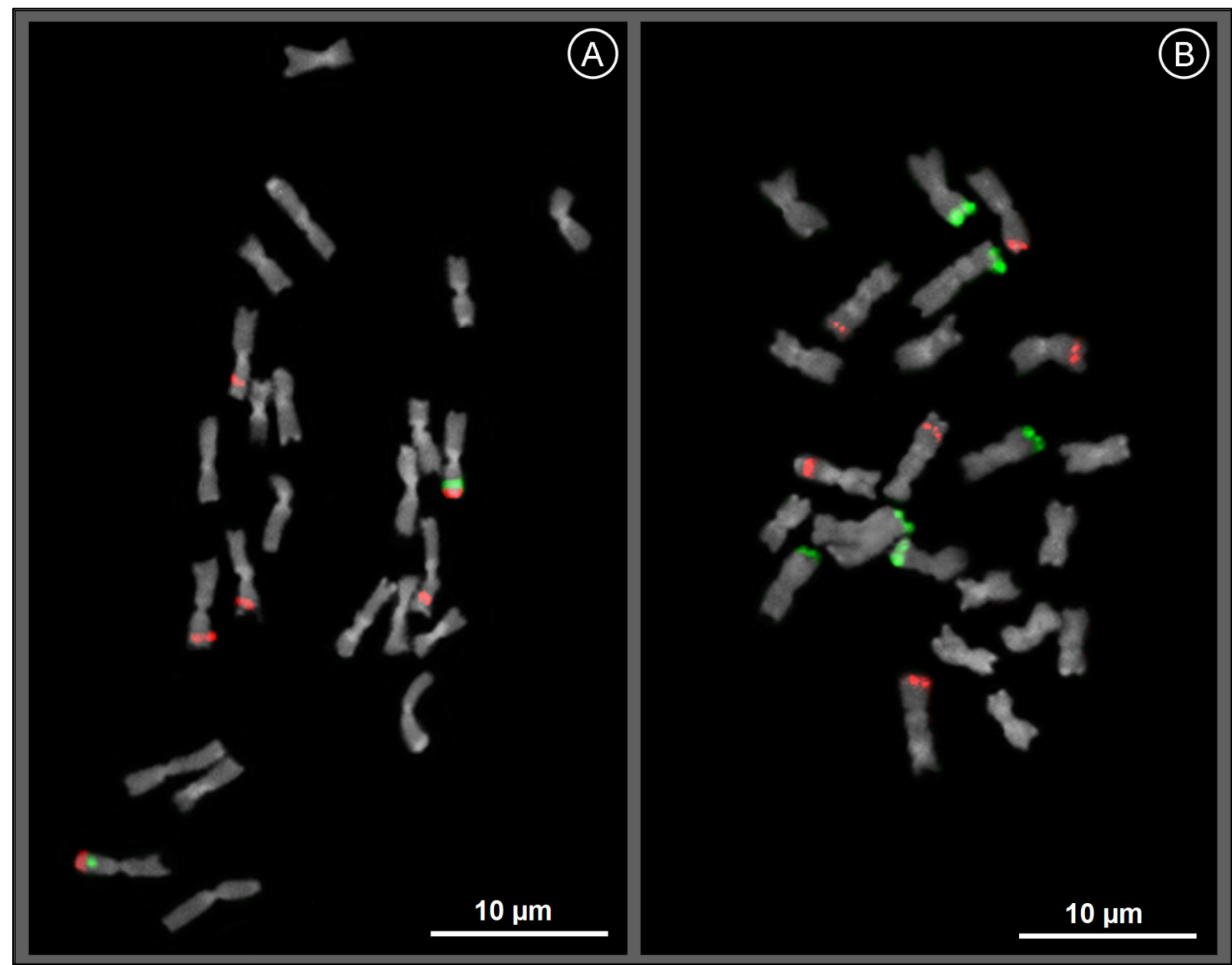

Figura 2. Metáfases mitóticas de espécies de Mesosetum sect. Bifaria com $2 n=24$ cromossomos após hibridização in situ com DNAr 5S (fluorescente em alaranjado) e DNAr 45S (fluorescente em verde) com contracoloração em DAPI (cinza) vistas em microscópio com epifluorescência. A. M. chaseae (RCO 2772). B. M. elytrochaetum (AROR 377). 


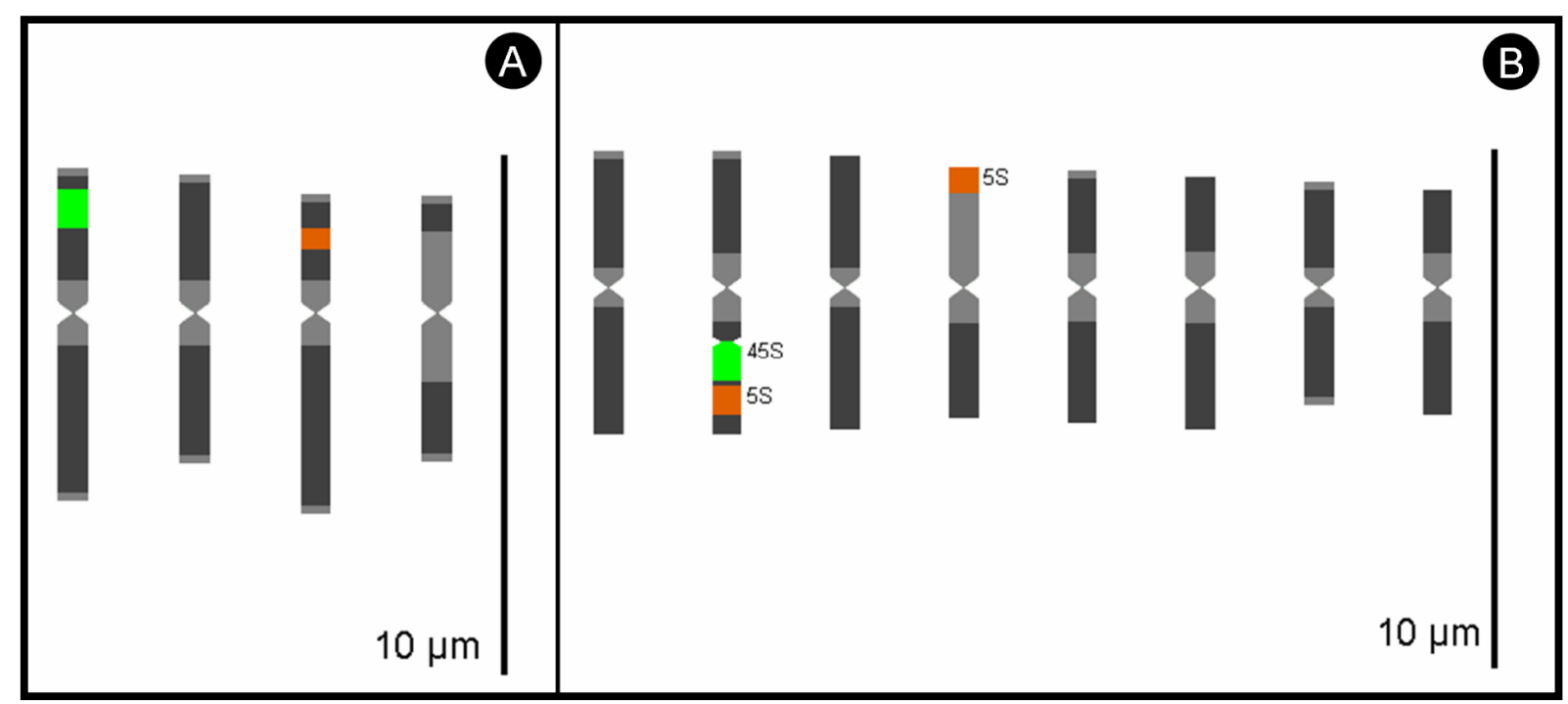

Figura 3. Idiogramas das espécies de Mesosetum sect. Bifaria com $2 n=8$ e $2 n=16$ cromossomos com sítios de DNAr 5S (laranja), DNAr 45S (verde) e bandas DAPI (cinza). A. M. ansantum (RCO 2766). B. M. compressum (ASS 274).

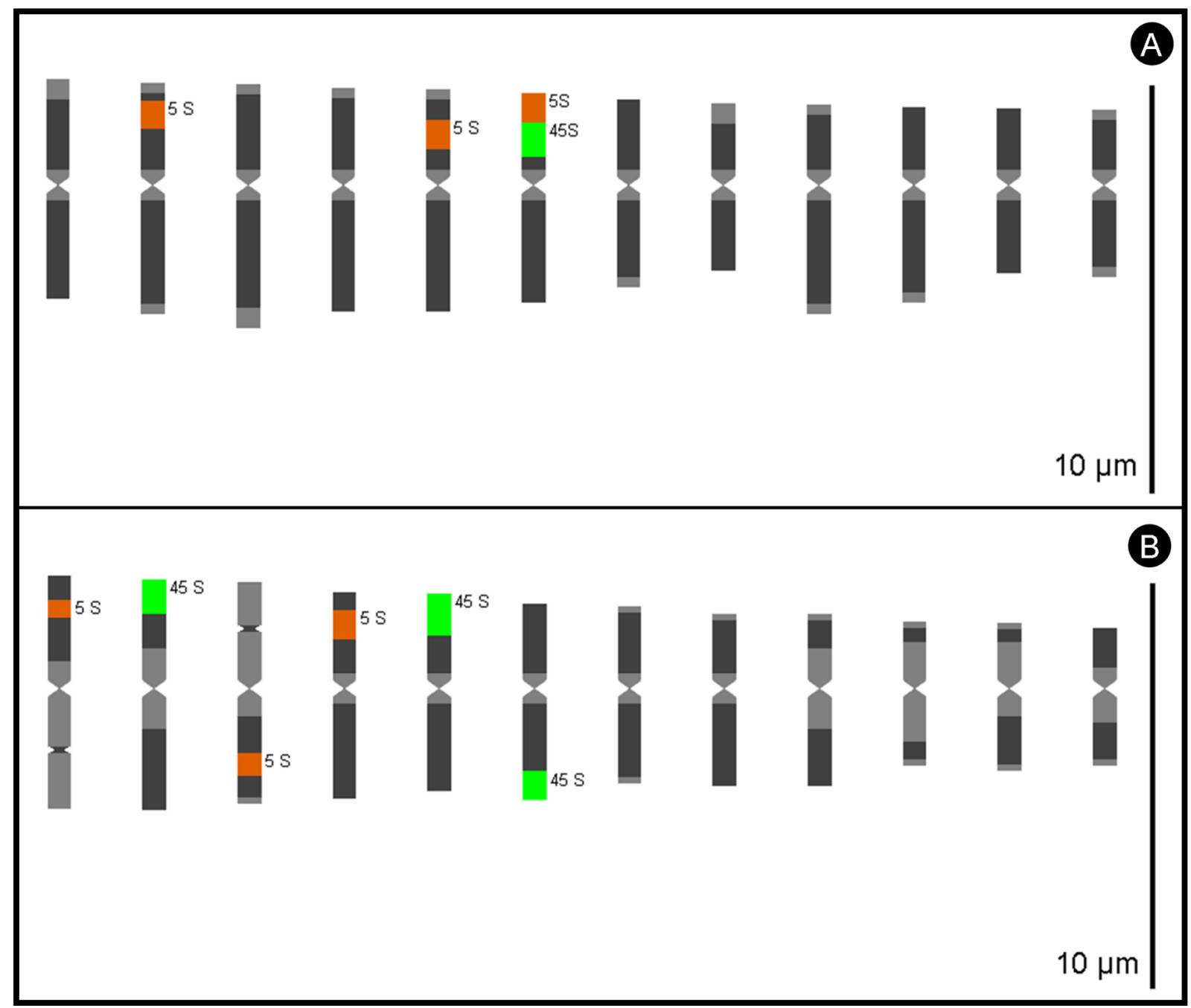

Figura 4. Idiogramas das espécies de Mesosetum sect. Bifaria com $2 \mathrm{n}=24$ cromossomos com sítios de DNAr 5S (laranja), DNAr 45S (verde) e bandas DAPI (cinza). A. M. chaseae (RCO 2772). B. M. elytrochaetum (AROR 377). 
Em M. ansatum $(2 \mathrm{n}=8)$ foram observados dois pares com marcações de DNAr, um com $5 \mathrm{~S}$ e outro com $45 \mathrm{~S}$. Em todos os cromossomos verificou-se uma intensa coloração DAPI terminal em ambos os braços, especialmente no braço curto (Figuras 1A, 3A). O par 1 apresentou um sítio subterminal de DNA 45S no braço curto (Figuras 1A, 3A). No par 3 foi verificada a ocorrência de sítio subterminal de DNAr 5S também no braço curto (Figuras 1A, 3A). Os outros dois pares foram diferenciados pela heterocromatina, sendo no par 2 a banda DAPI mais restrita a região pericentromérica e no par 4 a banda DAPI se estende desde a região pericentromérica até a porção subterminal do braço curto (Figuras 1A, 3A).

Em M. compressum $(2 \mathrm{n}=16)$ foram observados dois pares cromossômicos com sítios de DNAr, correspondentes ao par 2 e ao par 4 do cariótipo (Figuras 1B, 3B). No par 2 os dois sítios sintênicos de DNAr foram marcados no satélite, com um sítio de DNAr 5S subterminal e um sítio de DNAr 45S na constrição secundária (Figuras 1B, 3B). Ainda no par 2 foram observadas bandas de DAPI em mais duas regiões além da pericentromérica, uma subterminal no braço longo e outra colocalizada com o sítio de DNAr 45S (Figuras 1B, 3B). O par 4 foi marcado no braço curto com um sítio de DNAr 5S terminal e uma banda de DAPI subterminal. Bandas DAPI terminais nos braços curtos também foram observadas nos pares 1, 5 e 7 , sendo no par 7 também observadas no braço longo.

Em M. chaseae $(2 \mathrm{n}=24)$ os sítios de DNAr foram detectados em 3 pares cromossômicos, correspondentes aos pares 2, 5 e 6 do cariótipo (Figuras 2A, 4A). Os pares 2 e 5 foram marcados com um sítio subterminal de DNAr 5S no braço curto (Figuras 2A, 4A). O par 6 foi marcado com dois sítios sintênicos no braço curto, um terminal com DNAr 5S e outro subterminal com DNAr 45S (Figuras 2A, 4A). Foram observadas bandas terminais DAPI em todos os pares, exceto no par 11 (Figuras 2A, 4A).

Em M. elytrochaetum $(2 \mathrm{n}=24)$ os sítios de DNAr foram detectados em 6 pares cromossômicos, correspondentes aos pares 1, 2, 3, 4, 5 e 6 (Figuras 2B, 4B). Os pares 2, 5 e 6 
foram marcados com um sítio terminal de DNAr 45S, sendo nos pares 2 e 5 localizado no braço curto e no par 6 localizado no braço longo (Figuras 2B, 4B). No par 5 este sítio de DNAr 45S emite do sinal é colocalizado com uma banda DAPI terminal (Figuras 2B, 4B). Os pares 1, 3 e 4 foram marcados com um sítio de DNAr 5S subterminal, sendo localizado nos braços curtos dos pares 1 e 4 e no braço longo do par 3 (Figuras 2B, 4B). Foram observadas bandas terminais DAPI nos pares 7, 8, 9, 10, 11 e 12 (Figuras 2B, 4B).

\subsection{Discussão}

As colorações DAPI somadas às marcações de DNAr $5 \mathrm{~S}$ e $45 \mathrm{~S}$ foram úteis à distinção dos pares cromossômicos e determinação do cariótipo e são pela primeira vez estudadas e descritas no gênero Mesosetum e na subtribo Arthropogoninae.

As bandas DAPI estão associadas ao acúmulo de heterocromatina rica em DNA repetitivo AT (Souza et al. 2009; Souza et al. 2012) e foram observadas na região pericentromérica e também próximo à constrição secundária. Esta heterocromatina pericentromérica pode apresentar função de estabilizar o centrômero e garantir regularidade na segregação dos cromossomos durante a mitose e meiose, além participar na formação dos cromocentros durante a interfase, contribuindo na condensação e estruturação dos cromossomos (Simon et al. 2015).

Estas bandas DAPI nas regiões pericentroméricas foram distintas em alguns cromossomos, se estendendo por quase todo o braço cromossômico, semelhante ao observado em espécies de Paspalum por Vaio et al. (2005) e auxiliaram na distinção dos pares homólogos para elaboração do cariótipo.

Em $M$. ansatum $(2 \mathrm{n}=8)$, a presença de dois cromossomos com sítio de DNAr 5S e dois com sítio de DNAr 45S, reforça a diploidia para o genoma com 2n $=8$ em Mesosetum e suporta sua formação a partir do número cromossômico básico $\mathrm{x}=4$. Estes resultados 
contrastam com o obtido em Zingeria trichopoda $(2 n=8)$, espécie em que foram encontrados quatro cromossomos com sítio de DNAr $5 \mathrm{~S}$ e dois cromossomos com sítio de DNAr 45S, que confirmaram $2 \mathrm{n}=8$ como nível tetraploide no gênero Zingeria (Kotseruba et al. 2003, 2005; Kim et al. 2009).

Em M. compressum $(2 \mathrm{n}=16)$, os quatro cromossomos com sítios de DNAr $5 \mathrm{~S}$ e os dois cromossomos com sítio de DNAr $45 \mathrm{~S}$ evidenciaram a tetraploidia para $2 \mathrm{n}=16$ em Mesosetum. Resultados semelhantes foram obtidos no alotetraploide Zingeria trichopoda, que embora tenha número cromossômico diferente $(2 \mathrm{n}=8)$, também apresentou quatro cromossomos com sítio de DNAr 5S e os 2 cromossomos com sítio de DNAr $45 \mathrm{~S}$ (Kotseruba et al. 2003; Kotseruba et al. 2005; Kim et al. 2009). A principal diferença entre os tetraploides de Mesosetum e Zingeria é a posição dos sítios de DNAr nos cromossomos, sendo em Mesosetum um sítio de DNAr 5S sintênico ao sítio 45S em um par cromossômico e em Zingeria não há sintenia entre os sítios de DNAr 5S e 45S.

Em M. compressum os sítios de DNAr 45S parecem ter sido perdidos em um par cromossômico durante o curso da evolução, visto que seriam esperados quatro cromossomos com sítios de DNAr 45S no tetraploide após a duplicação do genoma. Resultados similares foram observados no alotetraploide Z. trichopoda, no qual também foi constatada perda do sítio de DNAr 45S em dois cromossomos (Kotseruba et al. 2003; Kotseruba et al. 2005; Kim et al. 2009). Em Z. trichopoda a perda de DNA foi comprovada pela análise de marcadores ITS que mostraram a eliminação de seqüências de DNAr 45S na comparação com o diploide Z. biebersteiniana, o qual é o progenitor de metade do genoma de Z. trichopoda (Kotseruba et al. 2003; Kotseruba et al. 2005; Kim et al. 2009). Em M. compressum ainda não foi possível identificar se origem do genoma se é auto ou alotetraploide o que dificulta estabelecer se houve perda, translocação ou fusão de sítios de DNAr 45S ao longo da evolução. 
Em $M$. chaseae $(2 n=24)$ também foram encontrados cromossomos com sítios sintênicos de DNAr com 45S em posição mais proximal ao centrômero e $5 \mathrm{~S}$ em posição mais distal ao centrômero. Estes cromossomos sintênicos com mesmas posições proximais e distais dos sítios de DNAr também foram encontrados em M. compressum, o que corrobora a filogenia de Mesosetum, na qual estas duas espécies formam um clado fortemente suportado (Silva dados não publicados).

Em M. elytrochaetum $(2 \mathrm{n}=24)$ o conjunto cromossômico representa quase perfeitamente 6 vezes o complemento genômico confirmando hexaploidia. Foram observados 6 cromossomos com 1 sítio de DNAr 5S e 6 cromossomos com sítio de DNAr 45S. Tendo em vista a ausência de espécie com nível hexaploide em $2 \mathrm{n}=24$ caracterizada por FISH de DNAr 5S e 45S, os resultados foram comparados com espécies hexaploides de Poaceae com números cromossomos distintos.

No gênero Avena L., também foram encontrados 6 cromossomos com sítios de DNAr 45S nos hexaploides silvestres $(2 \mathrm{n}=42, \mathrm{x}=7)$ de A. sativa L. e A. sterilis L. (Tomás et al. 2016). Em Zingeria, no hexaploide Z. kochii (Mez) Tzvelev $(2 \mathrm{n}=12, \mathrm{x}=2)$ foram observados sítios de DNAr 5S também em seis cromossomos (Kotseruba et al. 2010). Já a presença de sítios de DNAr 45S em apenas 4 cromossomos é atribuída a perda de DNAr 45S durante a evolução do alohexaploide Z. kochii (Kotseruba et al. 2010).

Foram observadas diferenças entre os cariótipos das espécies com $2 \mathrm{n}=24$, . chaseae e M. elytrochaetum, as quais evidenciaram tendências evolutivas divergentes, embora estejam em um subclado altamente suportado e com morfologia bastante homogênea (Swallen 1937, Filgueiras 1986, 1989; Silva et al. 2015; Silva et al. 2016; Silva dados não publicados). Enquanto os sítios de DNAr 5S e 45S são sintênicos em dois cromossomos de M. chaseae, não foi observada sintenia de DNAr em nenhum cromossomo de M. elytrochaetum. Estas diferenças sugerem evolução a partir de linhagens distintas, ou ainda que houve perda ou 
translocação de DNAr entre os cromossomos de M. chaseae. Uma maior perda de DNA já foi comprovada no genoma de $M$. chaseae $(2 \mathrm{n}=24)$ que apresenta $2 \mathrm{C}=5,7903 \mathrm{pg}$, o qual é quase $37 \%$ menor que o genoma de $M$. elytrochaetum $(2 \mathrm{n}=24)$ com $2 \mathrm{C}=9,0172 \mathrm{pg}$ (Capítulo 2 desta tese).

\subsection{Conclusão}

Os resultados do presente capítulo corroboram a hipótese de evolução por poliploidia entre as espécies de $M$. sect. Bifaria, as quais estão incluídas no clado de Mesosetum com número cromossômico básico $\mathrm{x}=4$. O nível diploide é comprovadamente representado pelas espécies com $2 n=8$, a partir do qual evoluíram por poliploidia os níveis tetraploide $(2 n=4 x$ $=16)$ e hexaploide $(2 \mathrm{n}=6 \mathrm{x}=24)$. As diferenças estruturais entre os cromossomos sugerem que após a poliploidização ocorreram mudanças no genoma ocasionadas por perda ou modificação do DNA. A presença e ausência de cromossomos com sintenia nos sítios de DNAr parece ser indicador de que surgiram distintas linhagens evolutivas em espécies de Mesosetum com $\mathrm{x}=4$.

A caracterização via citogenética molecular dos cromossomos de outras populações e espécies deve ser estimulada para ampliar o conhecimento acerca da evolução e origem do número cromossômico básico $\mathrm{x}=4$ no gênero Mesosetum.

\subsection{Referências}

Amosova AV, Bolsheva NL, Samatadze TE, Twardovska MO, Zoshchuk SA, Andreev IO, Badaeva ED, Kunakh VA, Muravenko OV (2015) Molecular Cytogenetic Analysis of Deschampsia antarctica Desv. (Poaceae), Maritime Antarctic. PLoS ONE 10(9): 1-17

Brasileiro-Vidal AC, Cuadrado A, Brammer SP, Zanatta ACA, Prestes AM, MoraesFernandes MIB, Guerra M (2003) Chromosome characterization in Thinopyrum 
ponticum (Triticeae, Poaceae) using in situ hybridization with different DNA sequences. Genetics and Molecular Biology 26(4): 505-510

Burke SV, Wysocki WP, Zuloaga FO, Craine JM, Pires JC, Edger PP, Mayfield-Jones D, Clark LG, Kelchner SA, Duvall MR (2016) Evolutionary relationships in Panicoid grasses based on plastome phylogenomics (Panicoideae; Poaceae). BMC Plant Biology 16(140): $1-11$

Celarier R, Paliwal R (1957) Basic chromosome number of four in the subfamily Panicoideae of the Gramineae. Science 126: 1247

Cremonini R, Ruffini Castiglione M, Grif VG, Kotseruba VV, Punina EO, Rodionov AV, Muravenko OV, Popov KV, Samatadze TE, Zelenin AV (2003) Chromosome banding and DNA methylation patterns, chromatin organisation and nuclear DNA content in Zingeria biebersteiniana. Biologia Plantarum 46: 543-550

Cremonini R (2005) Low chromosome number angiosperms. Caryologia 58(4): 403-409

De Wet JMJ (1987) Hybridization and polyploidy in the Poaceae. In: Soderstrom TR, Hilu KW, Campbell CS, Barkworth MA (eds.) Grass systematics and evolution, Smithsonian Inst. Press., Washington DC, pp 188-194

Ferrari F (2010) Caracterização cromosssômica em cana-de-açúcar (Saccharum spp., Poaceae). Dissertação de Mestrado, Universidade Estadual de Campinas, Campinas-SP, Brazil

Filgueiras TS (1986) O gênero Mesosetum Steudel (Gramineae: Paniceae). Tese de Doutorado, Universidade Estadual de Campinas, Campinas-SP, Brazil

Filgueiras TS (1989) Revisão de Mesosetum Steudel (Gramineae: Paniceae). Acta Amazônica 19: $47-114$

Gerlach W, Bedbrook J (1979) Cloning and characterization of ribosomal RNA genes from wheat and barley. Nucleic Acids Research 7: 1869-1885 
Harper JA, Thomas ID, Lovatt JA, Thomas HM (2004) Physical mapping of rDNA sites in possible diploid progenitors of polyploid Festuca species. . Plant Systematics and Evolution 245: 163-168

Hilu K (2004) Phylogenetics and chromosomal evolution in the Poaceae (grasses). Australian Journal of Botany 52: 13-22

Jiang J, Gill BS (1994) Nonisotopic in situ hybridization and plant genome mapping: the first 10 years. Genome 37: 717-725

Kim ES, Bolsheva NL, Samatadze TE, Nosov NN, Nosova IV, Zelenin AV, Punina EO, Muravenko OV, Rodionov AV (2009) The unique genome of two-chromosome grasses Zingeria and Colpodium, its origin, and evolution. Russian Journal of Genetics 45 (11): 1329-1337

Kotseruba VV, Gernand D, Meister A, Houben A (2003) Uniparental loss of ribosomal DNA in the allotetraploid grass Zingeria tricopoda $(2 \mathrm{n}=8)$. Genome 46: 156-163

Kotseruba VV, Pistrick K, Gernand D, Meister A, Ghukasyan A, Gabrielyan I, Houben A (2005) Characterisation of the low-chromosome number grass Colpodium versicolor (Stev.) Schmalh. $(2 \mathrm{n}=4)$ by molecular cytogenetics. Caryologia 58(3): 241-245

Kotseruba VV, Pistrick K, Blattner FR, Kumke K, Weiss O, Rutten T, Fuchs J, Endo T, Nasuda S, Ghukasyan A, Houben A (2010) The evolution of the hexaploid grass Zingeria kochii $(\mathrm{Mez})$ Tzvel. $(2 \mathrm{n}=12)$ was accompanied by complex hybridization. Molecular Phylogenetics and Evolution 56: 146-155

Leitch IJ, Beaulieu JM, Chase MW, Leitch AR, Fay MF (2010) Genome Size Dynamics and Evolution inMonocots. Journal of Botany ID 862516: 1-18

Michelan TS, Trevisan R, Silva CRMd, Souza RFd, Luceño M, Vanzela ALL (2012) Morphological and genomic characterization of Rhynchospora tenuis complex (Cyperaceae) and its taxonomic implications. Rodriguésia 63(4): 1-10 
Morrone O, Aagesen L, Scataglini MA, Salariato DL, Denham SS, Chemisquy MA, Sede SM, Giussani LM, Kellogg EA, Zuloaga FO (2012) Phylogeny of the Paniceae (Poaceae: Panicoideae): integrating plastid DNA sequences and morphology into a new classification. Cladistics 28: 333-356

Murat F, Xu J-H, Tannier E, Abrouk M, Guilhot N, Pont C, Messing J, Salse J (2010) Ancestral grass karyotype reconstruction unravels new mechanisms of genome shuffling as a source of plant evolution. Genome Research 20: 1545-1557

Nielen S, Almeida LM, Carneiro VTC, Araujo ACG (2010) Physical mapping of rDNA genes corroborates allopolyploid origin in apomictic Brachiaria brizantha. Sexual Plant Reproduction 23: 45-51

Pedrosa A, Sandal N, Stougaard J, Schweizer D, Bachmair A (2002) Chromosomal Map of the Model Legume Lotus japonicus. Genetics 161(1661-1672):

Rao Y (1975) Evolutionary trends in the Indian Iseilema. Nature 255: 220-221

Ribeiro ARO (2013) Citogenética, reprodução e variabilidade morfológica de espécies de Mesosetum sect. Bifaria (Hack.) Chase (Poaceae: Paniceae). Dissertação de Mestrado, Universidade de Brasília, Brasília-DF, Brazil

Ribeiro ARO, Sousa MWS, Oliveira RC, Araujo ACG, Fagg CW, Pozzobon MT (2015) Cytological studies in four species of Mesosetum (Arthropogoninae) reveal the lowest chromosome number among the Neotropical Poaceae. Plant Systematics and Evolution 301(10): 2377-2386

Ruban A, Fuchs J, Marques A, Schubert V, Soloviev A, Raskina O, Badaeva E, Houben A (2014) B Chromosomes of Aegilops speltoides Are Enriched in Organelle GenomeDerived Sequences. Plos One 9(2): e90214

Sang Y, Liang GH (2000) Comparative physical mapping of the 18S-5.8S-26S rDNA in three Sorghum species. Genome 43: 22-28 
Santos CAG (2007) Revisão de Axonopus serie Suffulti G.A. Black (Poaceae: Paniceae) para o Brasil. Tese de Doutorado, Universidade de São Paulo, São Paulo-SP, Brazil

Shishido R, Sano Y, Fukui K (2000) Ribosomal DNAs: an exception to the conservation of gene order in rice genomes. Molecular and General Genetics 263: 586-591

Silva AS, Ribeiro ARO, Sousa MWS, Fagg CW, Falcão R, Oliveira RC (2015) Micromorphology of the upper anthecium in Mesosetum Steud. and related genera (Poaceae, Arthropogoninae) and its taxonomic applications. Rodriguésia 66(2): 645-657

Silva AS, Villarroel D, Ribeiro ARO, Oliveira RC (2016) Eleven new records of little known taxa of Mesosetum and Paspalum (Poaceae) from Brazil and Bolivia. Phytotaxa 268(1): 069-079

Silva AS (dados não publicados) Filogenia de Mesosetum Steud. (Paspaleae: Poaceae) com base caracteres moleculares. Tese de Doutorado, Universidade de Brasília, Brasília-DF, Brazil

Simon L, Voisin M, Tatout C, Probst AV (2015) Structure and Function of Centromeric and Pericentromeric Heterochromatin in Arabidopsis thaliana. Frontiers in Plant Science 6: Article 1049

Sousa MWS (2014) Citogenética e morfologia de espécies de Mesosetum Steud. (Poaceae, Paspaleae). Dissertação de Mestrado, Universidade de Brasília, Brasília-DF, Brazil Souza LGR, Crosa O, Winge H, Guerra M (2009) The karyotype of Nothoscordum arenarium Herter (Gilliesioideae, Alliaceae): A populational and cytomolecular analysis. Genetics and Molecular Biology 32(1): 111-116

Souza LGR, Crosa O, Speranza P, Guerra M (2012) Cytogenetic and molecular evidence suggest multiple origins and geographical parthenogenesis in Nothoscordum gracile (Alliaceae). Annals of Botany 109: 987-999 
Studer AJ, Schnable JC, Weissmann S, Kolbe AR, McKain MR, Shao Y, Cousins AB, Kellogg EA, Brutnell TP (2016) The draft genome of the C3 panicoid grass species Dichanthelium oligosanthes. Genome Biology 17(223): 1-18

Swallen JR (1937) The grass genus Mesosetum. Brittonia 2(4): 363-392

Tomás D, Rodrigues J, Varela A, Veloso MM, Viegas W, Silva M (2016) Use of Repetitive Sequences for Molecular and Cytogenetic Characterization of Avena Species from Portugal. International Journal of Molecular Sciences 17(203): 1-14

Vaio M, Speranza P, Valls JFM, Guerra M, Mazzella C (2005) Localization of the 5S and 45S rDNA Sites and cpDNA Sequence Analysis in Species of the Quadrifaria Group of Paspalum (Poaceae, Paniceae). Annals of Botany 96: 191-200 


\section{CAPÍTULO 4}

Estudos de viabilidade polínica em espécies de Mesosetum Steud. (Poaceae: Paspaleae) 


\subsection{Introdução}

A poliploidia tem sido um dos eventos mais importantes na evolução das espécies de Poaceae, sendo registrada em pelo menos $80 \%$ de suas espécies e estritamente relacionada com a meiose e gametogênese (De Wet 1987, Hunziker \& Stebbins 1987, Hilu 2004, Ortiz et al. 2013, Pozzobon et al. 2013).

Embora os poliploides instáveis normalmente exibam altas taxas de irregularidades no pareamento e segregação dos cromossomos, algumas de suas células reprodutivas executam divisão meiótica regular (De Wet 1987; Savidan et al. 2001; Paterson et al. 2004; Pagliarini \& Pozzobon 2005; Boldrini 2009; Eilam et al. 2010; Ortiz et al. 2013; Pozzobon et al. 2013; Bernardo Filho et al. 2014). Pela consolidação destas divisões regulares e estabilização da meiose, genomas poliploides tornam-se diploidizados gradualmente ao longo das gerações, exibindo pareamento em bivalentes, segre gação normal e gametas balanceados, viabilizando a formação de sementes férteis que irão garantir a permanência de futuras gerações (Nogler 1984, De Wet 1987, Savidan et al. 2001, Paterson et al. 2004, Boldrini 2009, Eilam et al. 2010). Esta tendência de diploidização tem sido confirmada em Paniceae s.l. (Sede et al. 2010).

No gênero Mesosetum Steud., os estudos citogenéticos tem confirmado a ocorrência de poliploidia durante sua evolução (Gould 1966; Gould \& Soderstrom 1967; Pohl \& Davidse 1971 Davidse \& Pohl 1972, Silva et al. 2012; Ribeiro 2013, Sousa 2014; Ribeiro et al. (2015). Um primeiro grupo de espécies com 2 n $=20$ e 60 cromossomos tem série poliploide que evoluiu a partir de $\mathrm{x}=10$, que é provavelmente mais basal em Mesosetum. Um segundo grupo de espécies com $2 \mathrm{n}=8,16,24$ e 32 cromossomos tem série poliploide que evoluiu a partir $\mathrm{x}=4$ (Ribeiro 2013; Sousa 2014; Ribeiro et al. 2015; Silva dados não publicados; Capítulos 1, 2 e 3 desta tese de doutorado). 
Os resultados de Ribeiro (2013) mostraram a ocorrência de estabilidade meiótica no nível tetraploide $(2 \mathrm{n}=16)$ em $M$. bifarium e no nível hexaploide em $M$. elytrochaetum $(2 \mathrm{n}=$ 24) com predomínio de bivalentes no pareamento e segregação balanceada e raros quadrivalentes e micronúcleos. Entretanto, para o hexaploide de $M$. chaseae $(2 \mathrm{n}=24)$, Ribeiro (2013) observou alta instabilidade da meiose com predomínio de aderências e associações múltiplas no pareamento e tétrades com alta freqüência de micronúcleos.

Apesar do avanço no conhecimento sobre a meiose das espécies de Mesosetum feito nos trabalhos de Silva et al. (2012), Ribeiro (2013), Sousa (2014) e Ribeiro et al. (2015), são escassos os estudos reprodutivos no gênero. Embora já haja conhecimento do Índice Meiótico - IM (Love 1949) para 10 espécies de Mesosetum, o único trabalho contemplando a viabilidade polínica foi o de Silva et al. (2012) que avaliou a fertilidade do pólen em dez acessos de $M$. chaseae Luces. Esta carência de estudos não permite inferir se a estabilização da meiose interferiu na fertilidade do pólen das espécies de Mesosetum, como em outros gêneros de Paniceae s.l (Techio et al. 2006; Felismino et al. 2011; Bernado Filho et al. 2014).

Desse modo, os objetivos deste trabalho foram examinar a viabilidade polínica e índice meiótico em espécies de Mesosetum de forma a complementar as informações já disponíveis na literatura e investigar a interferência da estabilidade na viabilidade polínica e como atuaram na evolução das espécies de Mesosetum.

\subsection{Material e Métodos}

As flores para análise da viabilidade polínica e índice meiótico foram obtidas de mudas de acessos provenientes de touceiras coletadas em expedições de campo nos estados de Goiás, Mato Grosso, Minas Gerais e Pernambuco. Os vouchers foram depositados no herbário da Universidade de Brasília, UB (acrônimo disponível em Thiers 2016). O cultivo das mudas foi conduzido na Casa de Vegetação da Fitopatologia, Universidade de Brasília. 
Para a viabilidade polínica foram analisados oito acessos incluindo sete espécies de Mesosetum (Tabela 1), com pelo menos 5000 pólens analisados de cada acesso, com pelo menos 1000 grãos analisados por flor. As técnicas utilizadas foram baseadas nas descritas por Pozzobon et al. (2011). As lâminas foram preparadas com anteras provenientes de flores imediatamente após a antese e a coloração foi feita com carmim-acético $2 \%$.

Tabela 1. Discriminação das espécies e acessos de Mesosetum com viabilidade polínica avaliada

\begin{tabular}{|c|c|c|c|}
\hline Espécie & Acesso & $\mathbf{N}^{\circ}$ Crom. & Local de Coleta \\
\hline Mesosetum alatum Filg. & RCO 2765 & $2 n=8$ & Brasil, Mato Grosso, Água Boa \\
\hline $\begin{array}{l}\text { Mesosetum ansatum } \\
\text { (Trin.) Kuhlm. }\end{array}$ & RCO 2766 & $2 \mathrm{n}=8$ & Brasil, Mato Grosso, Poconé \\
\hline $\begin{array}{l}\text { Mesosetum ansatum } \\
\text { (Trin.) Kuhlm. }\end{array}$ & RCO 2784 & $2 \mathrm{n}=8$ & $\begin{array}{l}\text { Brasil, Mato Grosso, Chapada } \\
\text { dos Guimarães }\end{array}$ \\
\hline $\begin{array}{l}\text { Mesosetum bifarium } \\
\text { (Hack.) Chase }\end{array}$ & ASS 235 & $2 n=16$ & Brasil, Goiás, Teresina de Goiás \\
\hline Mesosetum chaseae Luces & RCO 2772 & $2 n=24$ & Brasil, Mato Grosso, Poconé \\
\hline $\begin{array}{l}\text { Mesosetum compressum } \\
\text { Swallen }\end{array}$ & ASS 274 & $2 n=16$ & Brasil, Pernambuco, Pesqueira \\
\hline $\begin{array}{l}\text { Mesosetum elytrochaetum } \\
\text { (Hack.) Swallen }\end{array}$ & RCO 2722 & $2 n=24$ & Brasil, Goiás, Alto Paraíso \\
\hline $\begin{array}{l}\text { Mesosetum rottboellioides } \\
\text { (Kunth) Hitchc. }\end{array}$ & PAR 331 & $2 n=20$ & $\begin{array}{l}\text { Brasil. Minas Gerais, Grão } \\
\text { Mogol }\end{array}$ \\
\hline
\end{tabular}

A análise foi feita, através da classificação visual dos grãos, os quais foram contabilizados e identificados em diferentes tipos, sendo os grãos de pólen vazios, mal corados ou mal formados considerados inviáveis. As imagens foram obtidas em fotomicroscópio LEICA, do Laboratório de Criptógamas, Departamento de Botânica da UnB.

Para análise do índice meiótico as técnicas se basearam em Ribeiro et al. (2015). As inflorescências coletadas no campo ou a partir do florescimento das mudas cultivadas, foram fixadas e armazenadas a $4^{\circ} \mathrm{C}$ em solução Carnoy 3:1 (etanol:ácido acético, v/v). A coloração foi feita com carmim-acético $2 \%$. Foram examinadas pelo menos 200 tétrades por acesso para determinação do Índice Meiótico proposto por Love (1949). 


\subsection{Resultados}

Os acessos avaliados apresentaram, em geral, altos percentuais de pólens viáveis (Tabela 2, Figura 1), sendo de 82,18\% em M. alatum, 98,77\% em M. ansatum (média dos dois acessos), 73,90\% em $M$. bifarium, 91,70\% em $M$. compressum, 93,21\% em $M$. elytrochaetum e 95,05\% em $M$. rottboellioides.

Para a espécie $M$. chaseae, obteve-se uma baixa taxa de viabilidade, apresentando apenas $27,69 \%$ de grãos viáveis. Dentro dos grãos de pólen inviáveis, a grande maioria, com 6.610 grãos contabilizados, foi de grãos vazios, porém também foram observados grãos de pólen mal corados e mal formados (1 F-H). Alguns grãos de pólen apresentaram visualmente diferenças no tamanho (Figura $1 \mathrm{E}$ ).

Tabela 2. Viabilidade polínica e Índice Meiótico em espécies de Mesosetum

\begin{tabular}{|c|c|c|c|c|}
\hline Espécie & Acesso & $\begin{array}{c}\mathrm{N}^{\circ} \\
\text { Crom. }\end{array}$ & $\begin{array}{l}\text { Viabil. } \\
\text { Polínica }\end{array}$ & Índice Meiótico \\
\hline Mesosetum alatum Filg. & RCO 2765 & $2 n=8$ & $82,18 \%$ & $\mathrm{X}$ \\
\hline $\begin{array}{l}\text { Mesosetum ansatum } \\
\text { (Trin.) Kuhlm. }\end{array}$ & RCO 2766 & $2 n=8$ & $98,18 \%$ & $\begin{array}{c}96,49 \% \\
\text { (Ribeiro et al. 2015) }\end{array}$ \\
\hline $\begin{array}{l}\text { Mesosetum ansatum } \\
\text { (Trin.) Kuhlm. }\end{array}$ & RCO 2784 & $2 n=8$ & $99,16 \%$ & $\begin{array}{c}99,03 \% \\
\text { (presente estudo) }\end{array}$ \\
\hline $\begin{array}{l}\text { Mesosetum bifarium } \\
\text { (Hack.) Chase }\end{array}$ & ASS 235 & $2 n=16$ & $73,90 \%$ & $\begin{array}{c}90,82 \% \\
\text { (Ribeiro 2013) }\end{array}$ \\
\hline $\begin{array}{l}\text { Mesosetum chaseae } \\
\text { Luces }\end{array}$ & RCO 2772 & $2 n=24$ & $27,69 \%$ & $\begin{array}{c}22,22 \% \\
\text { (Ribeiro 2013) }\end{array}$ \\
\hline $\begin{array}{l}\text { Mesosetum compressum } \\
\text { Swallen }\end{array}$ & ASS 274 & $2 n=16$ & $91,70 \%$ & $\begin{array}{c}96,70 \% \text { (presente } \\
\text { estudo) }\end{array}$ \\
\hline $\begin{array}{l}\text { Mesosetum } \\
\text { elytrochaetum (Hack.) } \\
\text { Swallen }\end{array}$ & RCO 2722 & $2 n=24$ & $93,21 \%$ & $\begin{array}{c}75,93 \% \\
\text { (Ribeiro 2013) }\end{array}$ \\
\hline $\begin{array}{l}\text { Mesosetum } \\
\text { rottboellioides (Kunth) } \\
\text { Hitchc. }\end{array}$ & PAR 331 & $2 \mathrm{n}=20$ & $95,05 \%$ & $\begin{array}{c}100,00 \% \\
\text { (Sousa 2014) }\end{array}$ \\
\hline
\end{tabular}




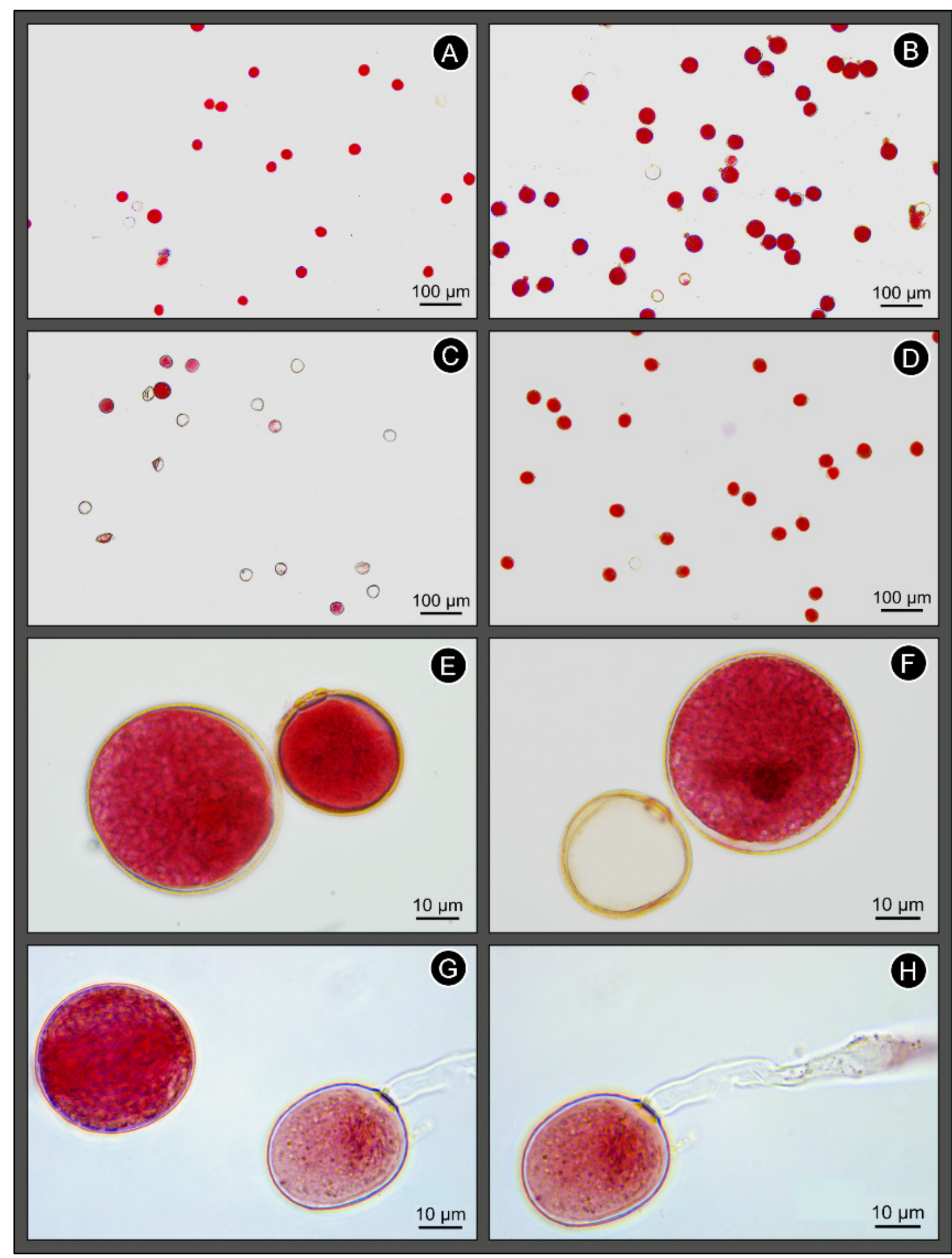

Figura 1. Grãos de pólen corados com carmim acético em espécies de Mesosetum. A-D. Vista geral da viabilidade dos grãos de pólen. A. M. alatum, RCO 2765. B. M. bifarium, ASS 235. C. M. chaseae, RCO 2772. D. M. rottboellioides, PAR 331. E-F. Detalhe de grãos de pólen de M. bifarium, ASS 235. E. Grãos de pólen bem corados com distintos tamanhos. F. Grão de pólen vazio ao lado de viável. G-H. Detalhe dos grãos de pólen de M. rottboellioides, PAR 331. G. Grão de pólen mal corado ao lado de viável. H. Grão de pólen mal corado germinando. 


\subsection{Discussão}

A viabilidade polínica relacionou-se diretamente com o índice meiótico (Tabela 2), sendo alta nos acessos com índices meióticos altos e baixa no acesso com índice meiótico baixo. De acordo com Pagliarini \& Pozzobon (2005) plantas com meiose instável têm como consequência uma baixa taxa de grãos de pólen viáveis devido a anormalidades no pareamento e segregação dos cromossomos.

Para as espécies $M$. ansatum, M. bifarium, M. compressum, M. elytrochaetum, $M$. rottboellioides, foram observadas taxas de viabilidade polínica acima de 70\%, corroborando a establilidade meiótica observada pelos trabalhos de Ribeiro (2013), Sousa (2014) e Ribeiro et al. (2015).

A baixa viabilidade polínica $(27,69 \%)$ do acesso investigado de $M$. chaseae (RCO $2772,2 \mathrm{n}=24)$, corrobora as análises de Ribeiro (2013) para este mesmo acesso, no qual foi observada uma taxa de irregularidade muito alta, sendo encontradas anormalidades meióticas em todas as fases.

Resultados diferentes foram observados por Silva et al. (2012), que observaram número cromossômico $2 \mathrm{n}=16$, meiose estável e alta viabilidade polínica em análise de distintas populações de $M$. chaseae provenientes do estado de Mato Grosso do Sul. A variação da viablidade polínica entre $60 \%$ e $90 \%$ nos distintos acessos observados por Silva et al. (2012) foi atribuída a fatores ambientais. Silva et al. (2012) classificou a viablidade polínica como alta, mesmo nos acessos com fertilidade em torno de $60 \%$, visto que houve compensação pelo grande número de grãos de pólen produzidos em cada flor.

Alguns grãos de pólen encontrados tiveram tamanhos desuniformes (Figura 1E). Normalmente, a presença de grãos de pólen maiores pode estar indicando, eventualmente, gametas não reduzidos ou, pelo menos gametas com número de cromossomos diferentes (Techio et al. 2006; Reis et al. 2008; Pozzobon et al. 2011; Bernardo Filho et al. 2014). 


\subsection{Conclusão}

Os resultados encontrados confirmam também em Mesosetum a relação direta entre o comportamento meiótico e a viabilidade polínica observada em Panicum L., Paspalum L. e Urochloa P. Beauv. (Valle \& Savidan 1996, Savidan et al. 2001, Hojsgaard et al. 2009, Ma et al. 2009, Ortiz et al. 2013, Hojsgaard et al. 2014). A alta viabilidade observada mesmo em poliploides indica que a estabilização da meiose tem contribuído para o restabelecimento da fertilidade do pólen. Novos estudos reprodutivos serão essenciais para confirmar a ocorrência deste padrão evolutivo nas demais espécies de Mesosetum.

\subsection{Referências}

Bernardo Filho RA, Santos AC, Souza FH, Valls JFM, Pagliarini MS (2014) Complete asynapsis resulting in 2n pollen formation in Paspalum jesuiticum Parodi (Poaceae). Genetics and Molecular Research 13(1): 255-261

Boldrini KR, Pagliarini MS, Valle CB (2009) Meiotic behavior of a nonaploid accession endorses $\mathrm{x}=6$ for Brachiaria humidicola (Poaceae). Genetics and Molecular Research 8(4): $1444-1450$

Davidse G, Pohl RW (1972) Chromosome numbers, meiotic behavior, and notes on some grasses from Central America and the West Indies. Canadian Journal of Botany 50: $1441-1452$

De Wet JMJ (1987) Hybridization and polyploidy in the Poaceae. In: Soderstrom TR, Hilu KW, Campbell CS, Barkworth MA (eds.) Grass systematics and evolution, Smithsonian Inst. Press., Washington DC, pp 188-194

Eilam T, Anikster Y, Millet E, Manisterski J, Feldman M (2010) Genome Size in Diploids, Allopolyploids, and Autopolyploids of Mediterranean Triticeae. Journal of Botany 2010: $1-12$ 
Felismino MF, Pagliarini MS, Valle CB, Resende RMS (2011) Meiotic stability in two valuable interspecific hybrids of Brachiaria (Poaceae). Plant Breeding 131: 402-408

Gould FW (1966) Chromosome numbers of some Mexican grasses. Canadian Journal of Botany 44: 1683-1696

Gould FW, Soderstrom TR (1967) Chromosome numbers of tropical American grasses. American Journal of Botany 54: 676-683

Hilu K (2004) Phylogenetics and chromosomal evolution in the Poaceae (grasses). Australian Journal of Botany 52: 13-22

Hojsgaard D, Honfi AI, Rua G, Daviña J (2009) Chromosome numbers and ploidy levels of Paspalum species from subtropical South America (Poaceae). Genetic Resources and Crop Evolution 56: 533-545

Hojsgaard D, Klatt S, Baier R, Carman JG, Hörandl E (2014) Taxonomy and Biogeography of Apomixis in Angiosperms and Associated Biodiversity Characteristics. Critical Reviews in Plant Sciences 33(5): 414-427

Hunziker JH, Stebbins GL (1987) Chromosome evolution in the Gramineae. In: Soderstrom TR, Hilu KW, Campbell CS, Barkworth MA (eds.) Grass Systematics and Evolution, Smithsonian Inst., Washington, pp 179-187

Love RA (1949) Estudos Citológicos Preliminares de Trigos Riograndenses. vol. Circular $n^{\circ}$ 74. Secretaria da Agricultura do Rio Grande do Sul, Porto Alegre-RS

Ma GH, Huang XL, Xu QS, Eric B (2009) Multiporate pollen and apomixis in Panicoideae. Pakistan Journal of Botany 41(5): 2073-2082

Nogler GA (1984) Gametophytic apomixis. In: Johri BM (ed.) Embriology of Angiosperms, Springer-Verlag, Berlin, pp 475-518 
Ortiz JPA, Quarin CL, Pessino SC, Acuña C, Martínez EJ, Espinoza F, Hojsgaard DH, Sartor ME, Cáceres ME, Pupilli F (2013) Harnessing apomictic reproduction in grasses: what we have learned from Paspalum. Annals of Botany 112: 767-787

Pagliarini MS, Pozzobon MT (2005) Meiose em vegetais: um enfoque para a caraterização de germoplasma. In: Peñaloza APS (coord.) Curso de Citogenética aplicada a Recursos Genéticos Vegetais, vol. Documentos 154 Embrapa Recursos Genéticos e Biotecnologia, Brasília-DF, pp 24-41

Paterson AH, Bowers JE, Chapman BA (2004) Ancient polyploidization predating divergence of the cereals, and its consequences for comparative genomics. Proceedings of the National Academy of Sciences of the United States of America 101(26): 9903-9908

Pohl RW, Davidse G (1971) Chromosome numbers of Costa Rican grasses. Brittonia 23: 293324

Pozzobon MT, Valls JFM (1997) Chromosome number in germplasm accessions of Paspalum notatum (Gramineae). Brazilian Journal of Genetics 20: 29-34

Pozzobon MT, Souza KRR, Carvalho SIC, Reifschneider FJB (2011) Meiose e viabilidade polínica em linhagens avançadas de pimenta. Horticultura Brasileira 29: 212-216

Pozzobon MT, Paganella MB, Santos S, Valls JFM (2013) Cytological and reproductive aspects in the Caespitosa group of Paspalum. Ciência Rural 43(11): 2004-2010

Reis CAO, Schifino-Wittmann MT, Dall'Agnol M (2008) Chromosome numbers, meiotic behavior and pollen fertility in a collection of Paspalum nicorae Parodi accessions. Crop Breeding and Applied Biotechnology 8: 212-218

Ribeiro ARO (2013) Citogenética, reprodução e variabilidade morfológica de espécies de Mesosetum sect. Bifaria (Hack.) Chase (Poaceae: Paniceae). Dissertação de MestradoDo, Universidade de Brasília, Brasília-DF, Brazil 
Ribeiro ARO, Sousa MWS, Oliveira RC, Araujo ACG, Fagg CW, Pozzobon MT (2015) Cytological studies in four species of Mesosetum (Arthropogoninae) reveal the lowest chromosome number among the Neotropical Poaceae. Plant Systematics and Evolution 301(10): 2377-2386

Savidan Y, Carman JG, Dresselhaus T (eds.) (2001) The Flowering of Apomixis: From Mechanisms to Genetic Engineering. ClMMYT, IRD, European Commission OC VI (FAIR), México-DF

Sede S, Escobar A, Morrone O, Zuloaga FO (2010) Chromosome studies in American Paniceae (Poaceae-Panicoideae). Annals of the Missouri Botanical Garden 97: 128-138

Silva AS (dados não publicados) Filogenia de Mesosetum Steud. (Paspaleae: Poaceae) com base caracteres moleculares. Tese de Doutorado, Universidade de Brasília, Brasília-DF, Brazil

Silva LAC, Pagliarini MS, Santos SA, Silva N, Souza VF (2012) Chromosome number, microsporogenesis, microgametogenesis, and pollen viability in the Brazilian native grass Mesosetum chaseae (Poaceae). Genetics and Molecular Research 11(4): 41004109

Sousa MWS (2014) Citogenética e morfologia de espécies de Mesosetum Steud. (Poaceae, Paspaleae). Dissertação de Mestrado, Universidade de Brasília, Brasília-DF, Brazil

Techio VH, Davide LC, Pedrozo CÂ, Pereira AV (2006) Viabilidade do grão de pólen de acessos de capim-elefante, milheto e híbridos interespecíficos (capim-elefante $\mathrm{x}$ milheto). Acta Scientiarum Biological Sciences 28(1): 7-12

Thiers B (2016) Index Herbariorum: A global directory of public herbaria and associated staff. New York Botanical Garden's Virtual Herbarium. Available at: http://sweetgum.nybg.org/ih/, Accessed 02 Feb. 2016 
Valle CB, Savidan Y (1996) Genetics, cytogenetics, and reproductive biology of Brachiaria. In: Miles JW, Maass BL, Valle CB (eds.) Brachiaria: biology, agronomy and improvement Centro Internacional de Agricultura Tropical - CIAT, Empresa Brasileira de Pesquisa Agropecuária - EMBRAPA, Cali, Colombia, pp 147-163 


\section{CONCLUSÕES GERAIS DA TESE}

1) A evolução por meio de mudanças em ordem cromossômica orginou pelo menos três linhagens em Mesosetum correspondentes aos números básicos $\mathrm{x}=4, \mathrm{x}=10 \mathrm{e} \mathrm{x}=13$, suportando os dados propostos pela filogenia molecular elaborada para o gênero.

2) As espécies de Mesosetum com número cromossômico básico x $=10$ são provavelmente mais basais e compartilham genoma pequeno como observado em outros gêneros também pertencentes à tribo Paspaleae.

3) $\mathrm{O}$ clado $\mathrm{x}=10$ parece ter mantido o conjunto cromossômico mais conservado e semelhante ao ancestral de Mesosetum.

4) $\mathrm{O}$ clado $\mathrm{x}=4$ e a linhagem monoespecífica com $\mathrm{x}=13$, derivados a partir de $\mathrm{x}=10$, seguiram rotas de evolução cromossômica divergentes, a primeira $(\mathrm{x}=4)$ por redução e a segunda $(\mathrm{x}=13)$ por aumento do número cromossômico.

5) A origem do número cromossômico $x=4$ por meio de um evento de redução abrupto a partir de $\mathrm{x}=10$ é pouco provável, pois implicaria na perda de seis pares cromossômicos, os quais correspondem a mais da metade do complemento genômico original com 10 cromossomos. É mais provável que esta redução tenha sido gradual e ocorrido por rearranjos ou fusão de cromossomos numa série de eventos que originaram números cromossômicos intermediários entre $\mathrm{x}=4 \mathrm{e} \mathrm{x}=10$, assim como em outros gêneros de Panicoideae e Pooideae.

6) Os dados de citometria de fluxo sugerem que houve ganho de DNA nas espécies de Mesosetum do clado $\mathrm{x}=4$ após sua origem a partir de cariótipo ancestral com cromossomos menores.

7) Esta expansão do tamanho do genoma refletiu no aumento do tamanho cromossômico nas espécies do clado $\mathrm{x}=4$ 
8) Os resultados com FISH corroboram a hipótese de evolução por poliploidia entre as espécies de $M$. sect. Bifaria, as quais estão incluídas no clado de Mesosetum com número cromossômico básico $\mathrm{x}=4$. O nível diploide é representado pelas espécies com $2 \mathrm{n}=8$, partir do qual evoluíram por poliploidia os níveis tetraploide $(2 \mathrm{n}=4 \mathrm{x}=16)$ e hexaploide $(2 \mathrm{n}=6 \mathrm{x}=$ 24). As diferenças estruturais entre os cromossomos sugerem que após a poliploidização ocorreram mudanças no genoma ocasionadas por perda ou modificação do DNA. A presença e ausência de cromossomos com sintenia nos sítios de DNAr parece ser indicador de que surgiram distintas linhagens evolutivas em espécies de Mesosetum com x $=4$. A alta viabilidade polínica observada mesmo em poliploides indica que a estabilização da meiose tem contribuído para o restabelecimento da fertilidade do pólen.

9) A origem de $x=13$ em Mesosetum pode ser relacionada a eventos de fissão ou duplicação de cromossomos a partir de um cariótipo original $\operatorname{com} x=10$. Estudos citogenéticos em novas populações de $M$. exaratum e espécies relacionadas morfologicamente devem ser estimulados para elucidar a origem de $\mathrm{x}=13$ em Mesosetum.

10) A ampliação dos estudos envolvendo contagens cromossômicas e caracterização citogenética avançada deve ser encorajada para investigar como surgiram os números cromossômicos raros, $\mathrm{x}=4 \mathrm{e} \mathrm{x}=13$, encontrados em Mesosetum. A caracterização citogenética de outros gêneros e espécies de Arthropogoninae e Paspaleae também deve ser conduzida, tendo em vista que auxiliará e complementará o conhecimento acerca da evolução cromossômica em Mesosetum. Deve haver um enfoque especial nas espécies com distribuição geográfica restrita, com poucos registros de herbário e florescimento estimulado pelo fogo, fatores que tem dificultado sua localização e, portanto, sua caracterização citogenética. Estes fatores contribuem para que estas espécies permaneçam até hoje com número cromossômico desconhecido. 